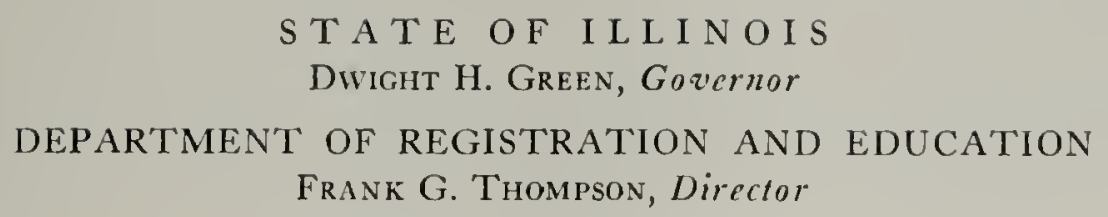

\title{
Wetwood of Elms
}

\author{
J. CEDRIC CARTER
}

Printed by Authority of the State of Illinois

U R B A NA, I L L I N O I S

August 1945 
S T A T E OF I L L I N O IS

Dwight H. Green, Governor

DEPARTMENT OF REGISTRATION AND EDUCATION

Frank G. Thompson, Director

\title{
BOARD OF NATURAL RESOURCES AND CONSERVATION
}

Frank G. THOMpSON, Chairman

William Trelease, D.Sc., LL.D., Biology*

Ezra J. Kraus, Ph.D., D.Sc., Forestry

Arthur CutTs Willard, D.Eng., LL.D.,

President of the University of Illinois

L. R. Howson, B.S.C.E., C.E., Engineering

Norman L. Bowen, Ph.D., Geology

Roger Adams, Ph.D., D.Sc., Chemistry

\section{NATURAL HISTORY SURVEY DIVISION Urbana, Illinois}

\author{
Scientific and Technical Staff \\ Theodore H. Frison, Ph.D., Chief \\ Florence A. Nyberg, Assistant to the Chief
}

Section of Economic Entomology

G. C. Decker, Ph.D., Entomolgist

M. D. FARRAR, Ph.D., Research Entomologist

J. H. Bigger, M.S., Associate Entomologist

S. C. Chandler, B.S., Southern Field Entomologist

JAMES W. APPLE, M.S., Northern Field Entomologist

B. G. Berger, M.A., A ssistant Entomologist

JoHN M. WRIGHT, B.A., Assistant Entomologist (on leave)

H. B. Petty, Jr., M.A., Associate in Entomology Extension

C. J. Weinman, Ph.D., Special Research Assistant

Willis N. BRUCE, B.S., Special Research Assistant

\section{Section of Insect Survey}

H. H. Ross, Ph.D., Systematic Entomologist

Carl O. Mohr, Ph.D., Associate Entomologist, Artist (on leave)

B. D. BURKs, Ph.D., Assistant Entomologist (on leave)

Milton W. Sanderson, Ph.D., Assistant Entomologist

Kathryn M. Sommerman, M.S., Artist, Entomological Assistant

Phyllis A. Beaver, Laboratory Assistant

\section{Section of Forestry}

James E. Davis, M.F., Extension Forester
Section of Aquatic Biology

George W. Bennett, Ph.D., Limnologist D. F. Hansen, Ph.D., Assistant Zoologist Paul G. Barnickol, M.A., Ichthyologist

Bruno von Limbach, M.S., Special Research Assistant

Section of Game Research and Management R. E. Yeatter, Ph.D., Game Specialist

Section of Wildlife Experimental Areas Arthur S. Hawkins, M.S., Game Technician (on leave)

F. C. Bellrose, JR., B.S., Assistant Game Technician

Harold C. Hanson, M.S., Assistant Game Technician

Section of Applied Botany and Plant Pathology

L. R. Tehon, Ph.D., Botanist

J. C. Carter, Ph.D., Assistant Botanist

G. H. Boewe, M.S., Field Botanist

J. L. Forsberg, M.S., Research Pathologist

Bessie B. Henderson, M.S., Research Assistant

Section of Publications

James S. AyARs, B.S., Technical Editor

ElEANOR G. WOLFF, B.Ed., Assistant Technical Editor

Technical Library

Marguerite Simmons, M.A., M.S., Technical Librarian

Consultants in Herpetology: Howard K. Gloyd, Ph.D., Director of the Museum, Chicago Academy of Sciences; Clifford H. POPE, B.S., Curator of Amphibians and Reptiles, Chicago Natural History Museum

*Deceased January 1, 1945.

This paper is a contribution from the Section of Applied Botany and Plant Pathology. 
$\mathrm{T}$ HE results which Dr. J. Cedric Carter reports in this article of the BulletiN of the Illinois Natural History Survey are the outcome of six consecutive years, 1939 through 1944, of study in the field, greenhouse and laboratory of a complex of disease manifestations in the American elm. The elements of this complex, singly and in various combinations, have puzzled both oractical and scientific tree experts for many bears.

Dr. Carter has demonstrated that there $s$ a direct relationship between an obscure tisease of the heartwood of living elms, ommonly called wetwood, and certain orms of twig and branch dieback, "bleedng" from crotches and wounds, and the wo conditions known to tree experts as nternal slime flux and external slime flux. te has isolated a species of bacterium, ipparently heretofore undescribed and unlamed, which can produce elements of this lisease complex upon being inoculated into iealthy trees.

Although supporting material and obervations were gathered in many places in llinois, the major part of the field work onnected with this investigation was done $n$ the Village of Hinsdale, in Du Page ¿ounty, Illinois. Much of the equipment ecessary for some of the studies and certain haterials, such as fertilizers, were furnished $y$ the Village, along with labor and other elp, as occasion demanded. Many of the lustrations in this paper show phases of hese Hinsdale studies.

Mr. Robert S. Hopkins, Commissioner of Public Works for the Village, furthered the work in all possible ways. With his approval, Mr. William Ellsworth Rose, as Forester, took an enthusiastic interest in the work from 1939 through 1941, and Mr. Joseph F. Shafer, Assistant Commissioner of Public Works, showed an equal interest from 1942 through 1944. These men gave generously of their time, assisting personally and assigning men employed under them to various tasks as need arose. Among such tasks may be mentioned the collecting of wood, gas and sap samples for laboratory testing, the felling and cutting up of certain trees, the periodical recording through 2 years of the readings of gauges installed in trees, the feeding of several trees and the setting up of a number of experiments. Also, through their reports to the Village President and Board of Trustees, Mr. Rose and Mr. Shafer kept the officials and citizens of Hinsdale informed regarding the progress of the investigation.

To acknowledge all of this help is a pleasure. The elements of personal and public interest did much to make Dr. Carter's study complete and exact in many details. Moreover, the cooperation between officials, of the Village of Hinsdale and scientists of the Illinois Natural History Survey, cordially maintained throughout, provides an example showing how communities in Illinois can proceed toward the solution of tree problems requiring the services of highly specialized scientists.

T. H. FRison, Chief

Illinois Natural History Survey. 



\section{CONTENTS}

Page
407

ACKNOWLEDGMENTS. . . . . . . . . . . . . . . . . . . . . . . . . . . . 407

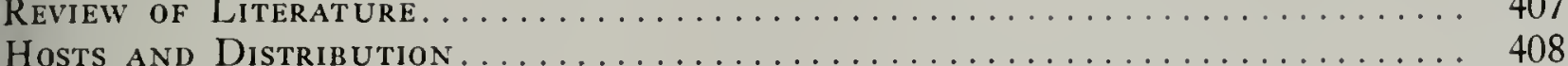

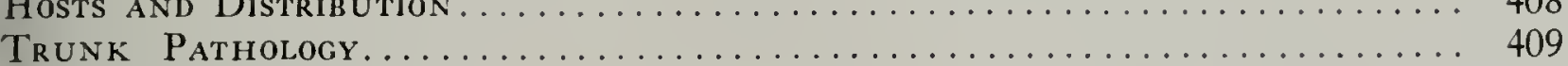

Wood Discoloration...................................... 409

Gas............................................ 410

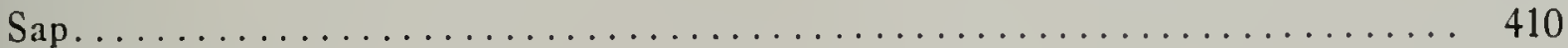

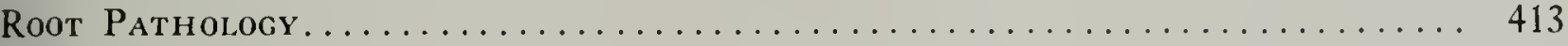

Branch PathologY...................................... 414

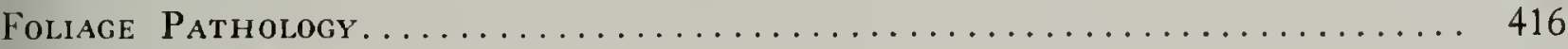

DisSECTEd ELM.................................... 417

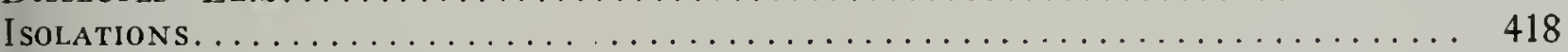

Histology ............................................. 419

The Wetwood Organisn. . . . . . . . . . . . . . . . . . . . . . . . . . . . . . 420

Morphology ....................................... 420

Cultural Characters..................................... 420

Biochemical Reaction.................................... 422

Taxonomy.......................................... 422

Erwinia nimipressuralis NEw SPECIES.......................... 423

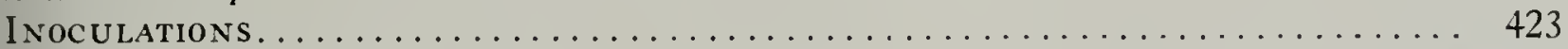

American Elm, Greenhouse Inoculations....................... 423

Siberian Elm, Greenhouse Inoculations. . . . . . . . . . . . . . . . . . . . . . . . 424

Toxicity Tests For WILT.................................... 425

Laboratory Tests on Cut Shoots . . . . . . . . . . . . . . . . . . . . . . . . . 425

Field Tests on 2-Year-Old Elms .......................... 426

Greenhouse Tests on 2-Year-Old Elms.......................... 427

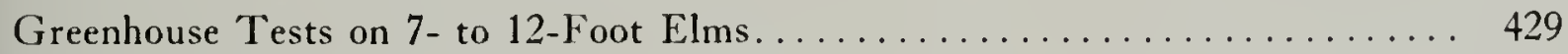

Pressures in Affected Elms................................... 430

Field Studies.......................................... 430

Greenhouse Studies................................... 433

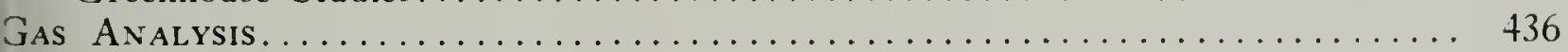

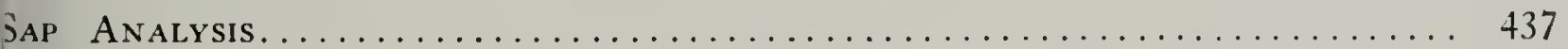

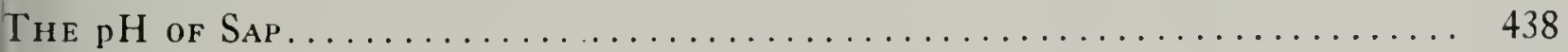

Control Studies.......................................... 439

Helione Injections and Feeding in $1940 \ldots \ldots \ldots \ldots \ldots \ldots \ldots \ldots \ldots \ldots \ldots$

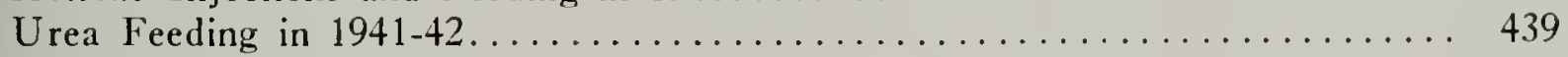

Drains Installed in $1942 \ldots \ldots \ldots \ldots \ldots \ldots \ldots \ldots \ldots \ldots \ldots \ldots \ldots \ldots \ldots \ldots$

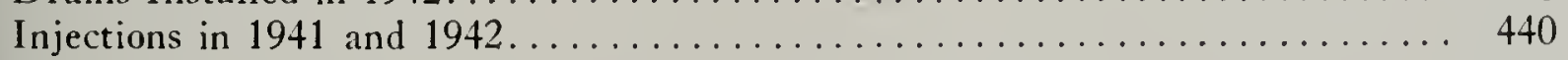

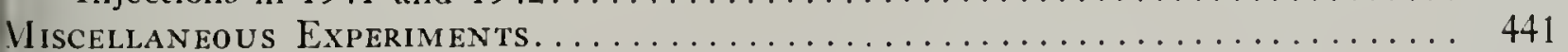

Injections of Toxic and Stimulatory Materials. . . . . . . . . . . . . . . . . 441

Distribution of Malachite Green in Elms . . . . . . . . . . . . . . . . . . . . . . 441

Soil Tests........................................... 443

Elm Seeds ........................................ 444

Growth Associations................................... 444

Conclusions. . ...................................... 444

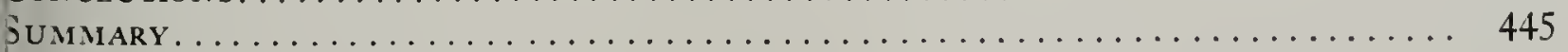

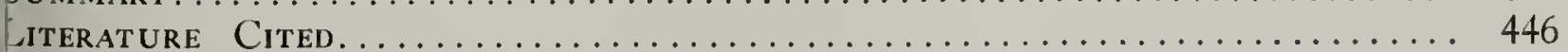




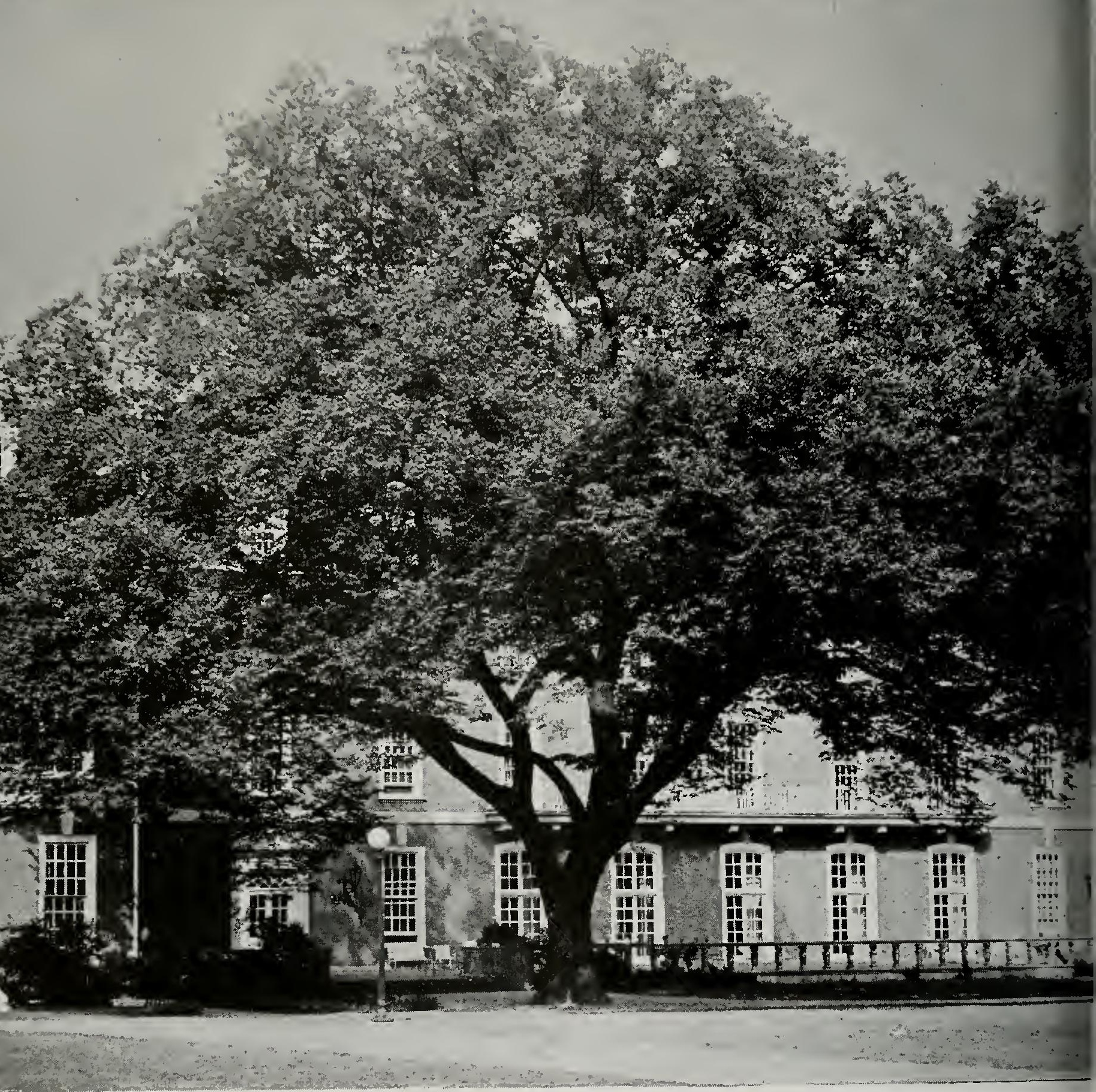

American elm on the University of Illinois campus.

The American elm, Ulmus americana L., unsurpassed in beauty and grace, is the most popular and widely planted shade tree in the Middle West. 


\section{Wetwood of Elms}

\section{J. CEDR I C C A R T E R}

T HE investigation of wetwood reported in this paper is the outgrowth of studies of an unusual wilt observed on a large number of American elms in the Village of Hinsdale, 1llinois, in July and August, 1939. As studies of the wilt progressed, it became apparent that this wilt was a secondary manifestation of disease intimately related to slime flux, a chronic bleeding at crotches and wounds, to abnormally high sap pressure in the trunk, and to wetwood, a water-soaked, darkly discolored condition of the heartwood. The investigation has shown that all of these conditions-wilting, high sap pressure and water-soaked, discolored wood-are phases of the wetwood disease, and that a bacterium, described as a new species, can cause wetwood in elms.

\section{Acknowledgments}

The author wishes to express his sincere appreciation to all those who have assisted in any way during the course of this investigation. Special recognition is given to the Village of Hinsdale forestersMr. W. E. Rose through $19+1$ and Mr. J. F. Shafer since 19+2-for their assistance with the portion of the investigation that was carried out at Hinsdale. Elms affected with wetwood on Hinsdale parkways were used in parts of this investigation. Permission to use these trees was arranged with the government of the Village of Hinsdale through $\mathrm{Mr}$. Robert 5. Hopkins, Commissioner of Public IVorks, and much of the labor, equipment and material used in treating and examining them was furnished by the Village. Dr. O. W. Rees and Dr. G. C. Finger, chemists of the Illinois State Geological Survey, gave many suggestions in regard to methods of analyzing sap and gas taken from affected elms. Some gas samples were analyzed by Mr. C. D. Lewis, Assistant Chemist of the Illinois State Geological Survey. Dr. F. M. Clark,
Assistant Professor of Bacteriology at the University of Illinois, made many helpful suggestions in connection with the identification of the bacterium associated with wetwood. Preliminary analyses of sap from wetwood-affected elms were run by Dr. F. F. Weinard, Associate Professor of Floricultural Physiology at the University of Illinois. Mr. O. T. Lay, in charge of the city office of the United States Department of Commerce Weather $\mathrm{Bu}$ reau at Chicago, furnished the monthly meteorological summaries for Chicago. Photographic illustrations for the frontispiece and for figs. 19, 20, 21 and 22 were prepared by Mr. Ray R. Hamm, Manager of the University of Illinois photographic and blueprinting laboratory. Mrs. Lucile Rogers Carter assisted in many ways in the preparation of this manuscript. The author is indebted to Dr. L. R. Tehon, head of the Section of Applied Botany and Plant Pathology of the Illinois Natural History Survey, for suggestions made during the course of this investigation.

\section{Review of Literature}

A bacterial vascular disease of Lombardy poplar, Populus nigra italica Muenchh., was described by Hartley \& Crandall (1935). Crandall, Hartley \& Davidson (1937) called this disease wetwood and described it as "a water-soaked condition of the central wood." They reported wetwood in species of Abies, Morus, Platanus, Populus, Prosopis, Prunus, Quercus, Salix, Tsuga and Ulmus, and also Elaeagnus cuttings.

Crandall, Hartley \& Davidson (1937) mentioned that slime flux, in several species, appeared to be a pathological phenomenon of wetwood. Dodge (1937), in a discussion of slime flux, stated, "A tree should not be diagnosed as suffering from slime flux unless there is a 'wet wood' condition of the heartwood and unless the bleeding of moisture from the tree issues from this heartwood." He pointed out 
that, in general, moisture is under pressure throughout the heartwood of such an affected tree. However, in a few cases he found pressure to be present only in isolated sections of the heartwood. May (1942) showed that bleeding or fluxing from the heartwood of elms affected with wetwood was independent of sap flow in the sapwood. He considered slime flux to be one of the manifestations of wetwood. Crandall (19+3), working with winter-injured Platanus acerifolia Willd. in 1934, found a bacterial infection to be present in wetwood-affected trunk wood. He suggested that the frost cracks that were present in the trees affected with wetwood had developed during periods of low temperature. The affected trees fluxed freely through these cracks. Large (1944) described a flux of tung tree as alcoholic flux or white slime flux and stated that the disease was confined to the cambial region. He found bacteria and an Actinomycete-like fungus associated with this type of flux.

Most of the work on slime flux before 1935 was concerned mainly with the visible manifestations of the disease on the outside of trees. Ludwig (1886, 1888, 1890) described alcoholic flux or white slime flux of oak, birch, poplar and maple, and brown slime flux of apple, elm, birch, horse chestnut, poplar and oak. He stated that in brown slime flux the sap or slime formed in the wood and broke through the bark, and both the bark and wood soon decayed. He associated Endomyces magnusii Ludw. with white slime flux, and Micrococcus dendroporthos Ludw. with brown slime flux.

Following Ludwig's early work, slime flux was investigated by Hansen (1889) in Denmark, by Holtz (1901) and Stautz (1931) in Germany, by Massee (1897, 1907) and Ogilvie (1924) in England, and by Stone (1916) and Cook (1918) in the United States. These investigators, with the exception of Ogilvie (1924), believed that slime flux was caused by parasitic organisms. Massee (1897) produced slime flux of apple and plum trees by inoculating them with Micrococcus dendroporthos Ludw. Stautz (1931) pointed out that no fungus hyphae were found in affected wood but that bacteria were present in drops of the sap. Tubeuf \& Smith (1897), Ward (1901) and Ogilvie
(1924) believed that slime flux was not a parasitic disease but an abnormal physiological bleeding associated with normal or abnormal pressures in the tree.

Guba (1934, 1942), after reviewing the literature, concluded that slime flux was not a parasitic disease but that it developed because of artificial environment and other mechanical or physiological conditions.

\section{Hosts and Distribution}

In Illinois, wetwood has been found in American elm, Ulmus americana L., including the varieties Moline and Littleford, slippery elm, Ulmus fulva Michx., English elm, Ulmus procera Salisb., and Siberian elm, Ulmus pumila L. Trees affected with this disease have been found in 40 towns and 21 counties, as follows: Quincy in Adams County; Champaign and

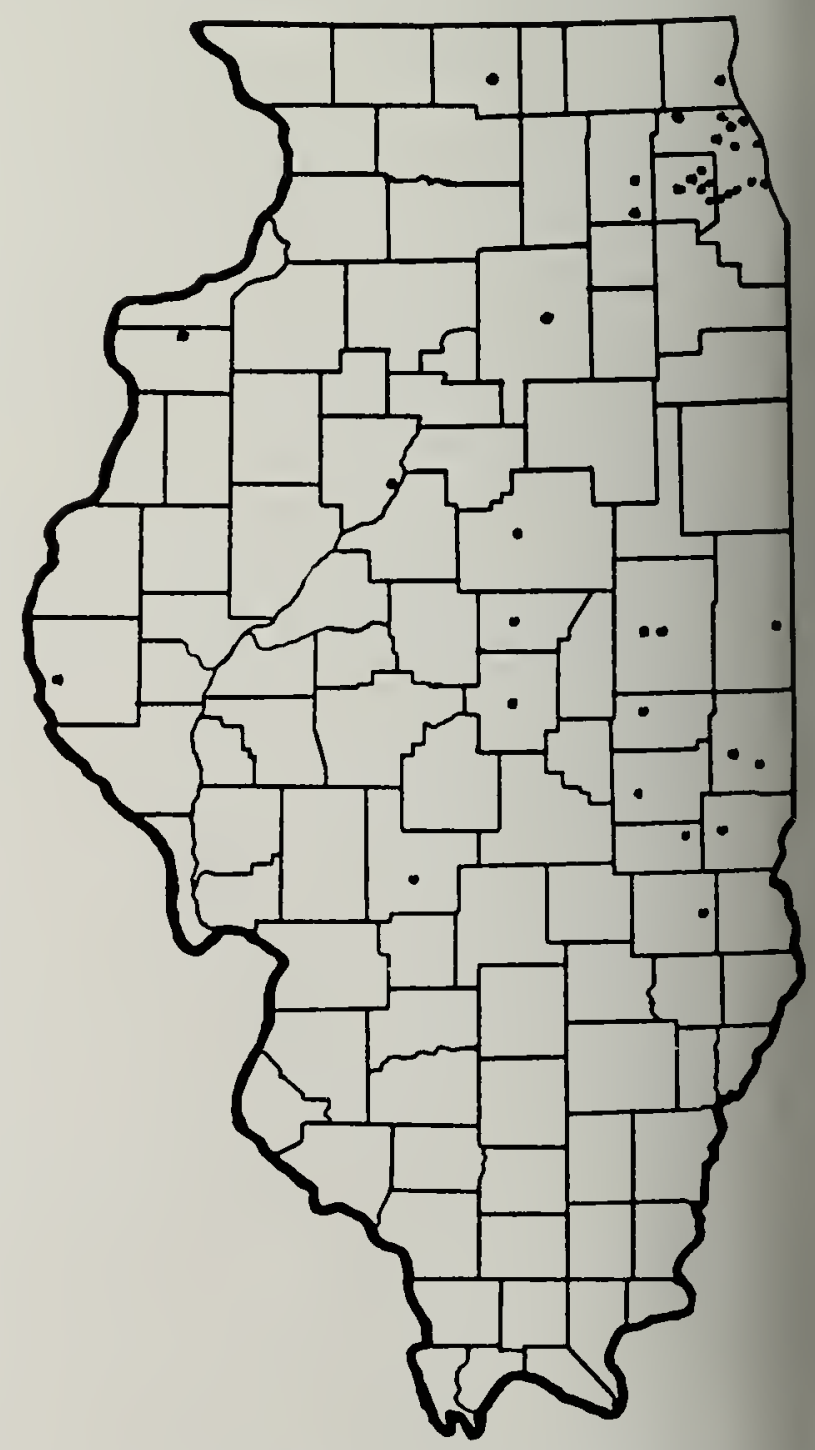

Fig. 1.-The black dots indicate the location of towns in which wetwood-affected elms have been found. 
Urbana in Champaign County; Martinsville in Clark County; Mattoon in Coles County; Barrington, Brookfield, Chicago, Des Plaines, Evanston, Glencoe, La Grange, Northbrook, Oak Park, Park Ridge, Techny and Western Springs in Cook County; Timothy in Cumberland County; Clinton in De IVitt County; Tuscola in Douglas County; Addison, Elmhurst, Glen Ellyn, Hinsdale, Lombard and Villa Park in Du Page County; Paris and Redmond in Edgar County; IVillow Hill in Jasper County; Aurora and St. Charles in Kane County; Lake Forest in Lake County; Ottawa in La Salle County ; Decatur in Macon County; Bloomington n McLean County; Hamlet in Mercer County; Hillsboro in Montgomery Coun; Peoria in Peoria County; Danville in Vermilion County and Rockford in $V$ innebago County. Distribution of the to towns is shown in fig. 1 .

\section{Trunk Pathology}

Wood Discoloration.-Wetwood in lms is characterized by dark brown dis-

\section{8

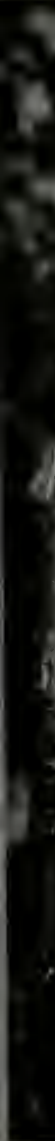

Fig. 2.-Section of elm trunk affected with retwood, showing discoloration of inner wood nd brown streaks in current-season wood. coloration that may appear in currentseason trunk wood as streaks or broken bands or in several annual rings as narrow to broad streaks or broken bands, fig. 2 . The discoloration sometimes extends beyond the current-season wood into the cambial region and phloem, fig. 3. There it is grayish brown and appears as short streaks or irregular, elongate patches. Discolored wood appears water-soaked. When it is cut, sap oozes out.

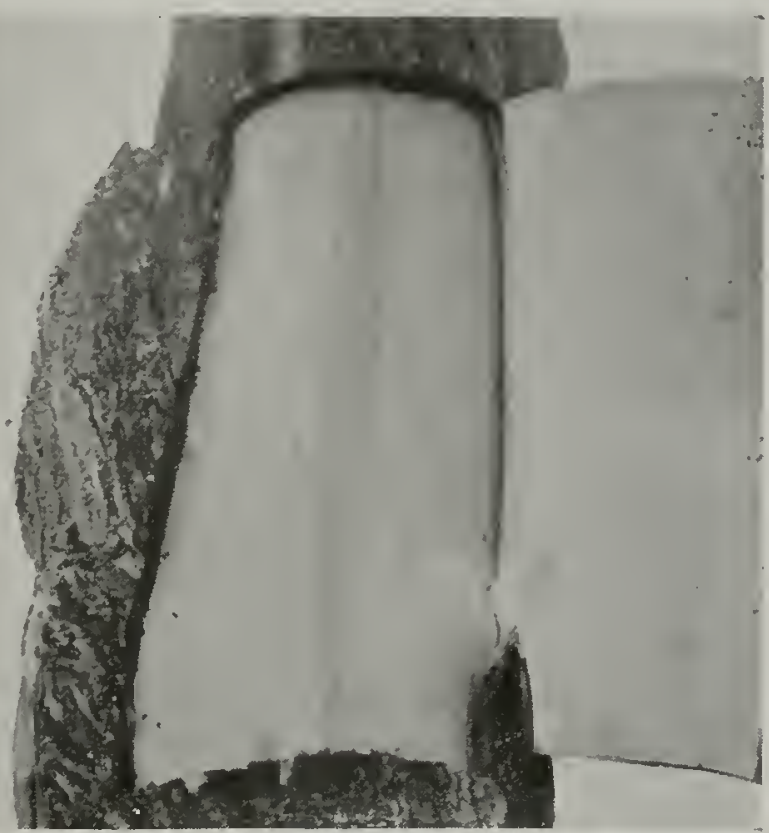

Fig. 3.-Wetwood discoloration can somelimes be found in the cambial region and phloem of elms, where it is grayish brown and shows as short streaks or elongate patches.

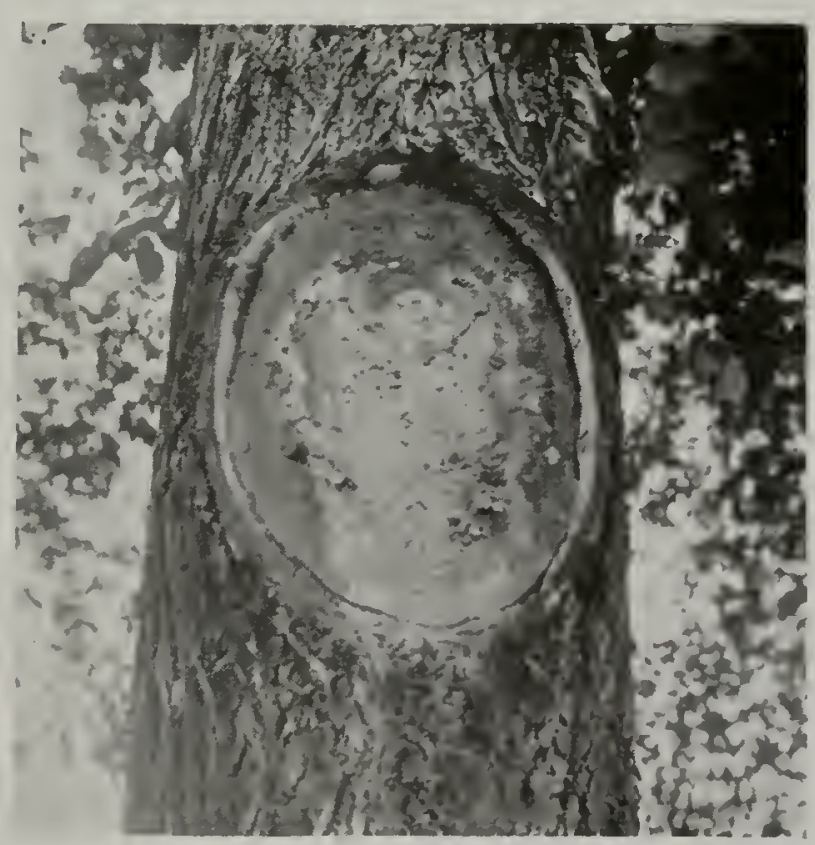

Fig. 4.-Fluxing through a wound made in the removal of a large branch. Toxicity of the flux from wetwood-affected elm prevents callus formation at the base of the cut. 


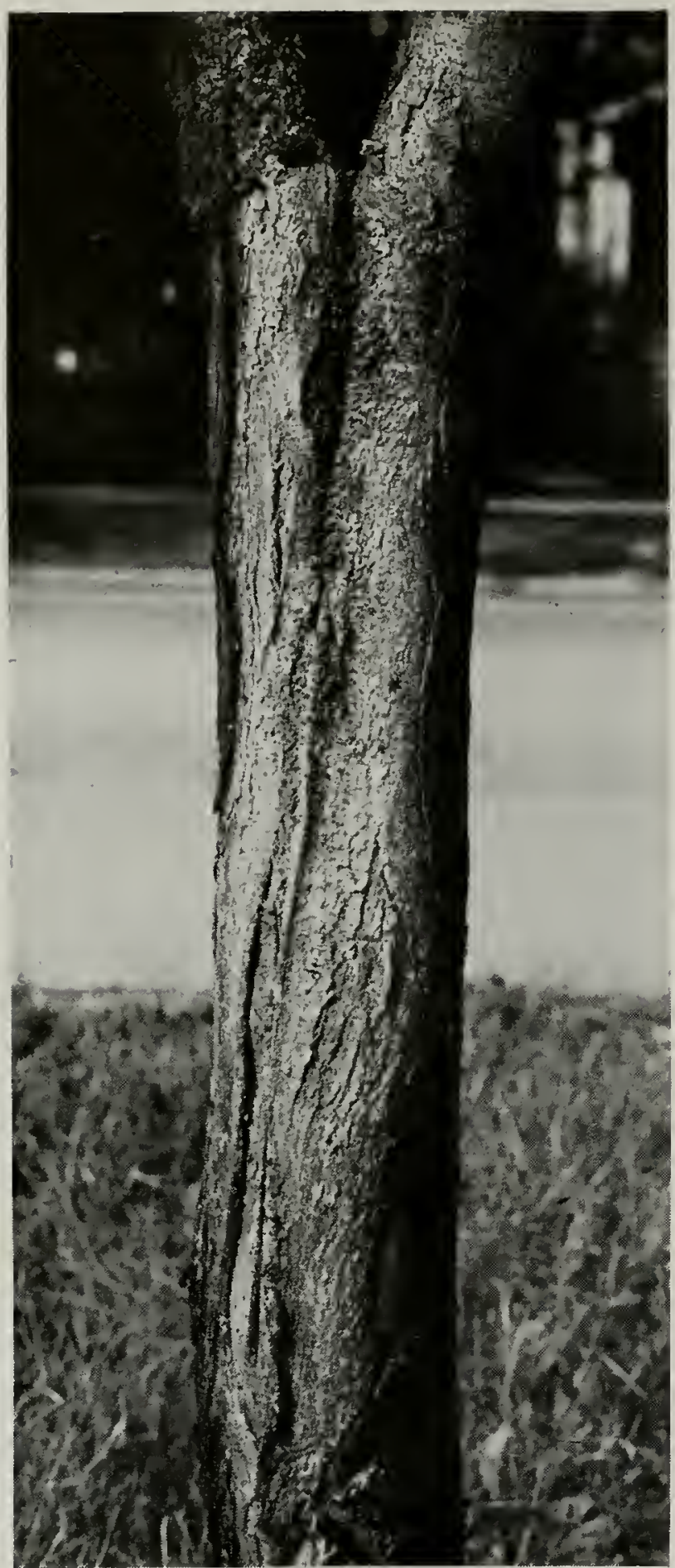

Fig. 5.-Fluxing through branch crotches is common in elms affected with wetwood. The flux on this tree, invaded by air-borne organisms, has coated the bark below the crotch with slime.

In most elms, wetwood is confined to the inner sapwood and heartwood, and there is very little or no streaking in the outer sapwood and no discoloration in the cambial region or phloem. However, in those affected elms that exhibit wilting of twigs and branches, grayish brown discoloration can be found in the outer sapwood and occasionally in the cambial region and phloem as well. as in older wood.
Gas.-In wetwood-affected tissues, gas is produced in large amounts by the action of the fermenting bacteria on carbohydrates and other materials in the trunk. This gas, confined in the trunk, causes abnormally high sap pressures to develop. Pressures up to 60 pounds per square inch have been recorded.

Sap.-Sap accumulates in abnormally large amounts in affected wood. Because of the abnormally high pressure caused by the gas produced by fermentation, sap frequently is forced out of the trunk

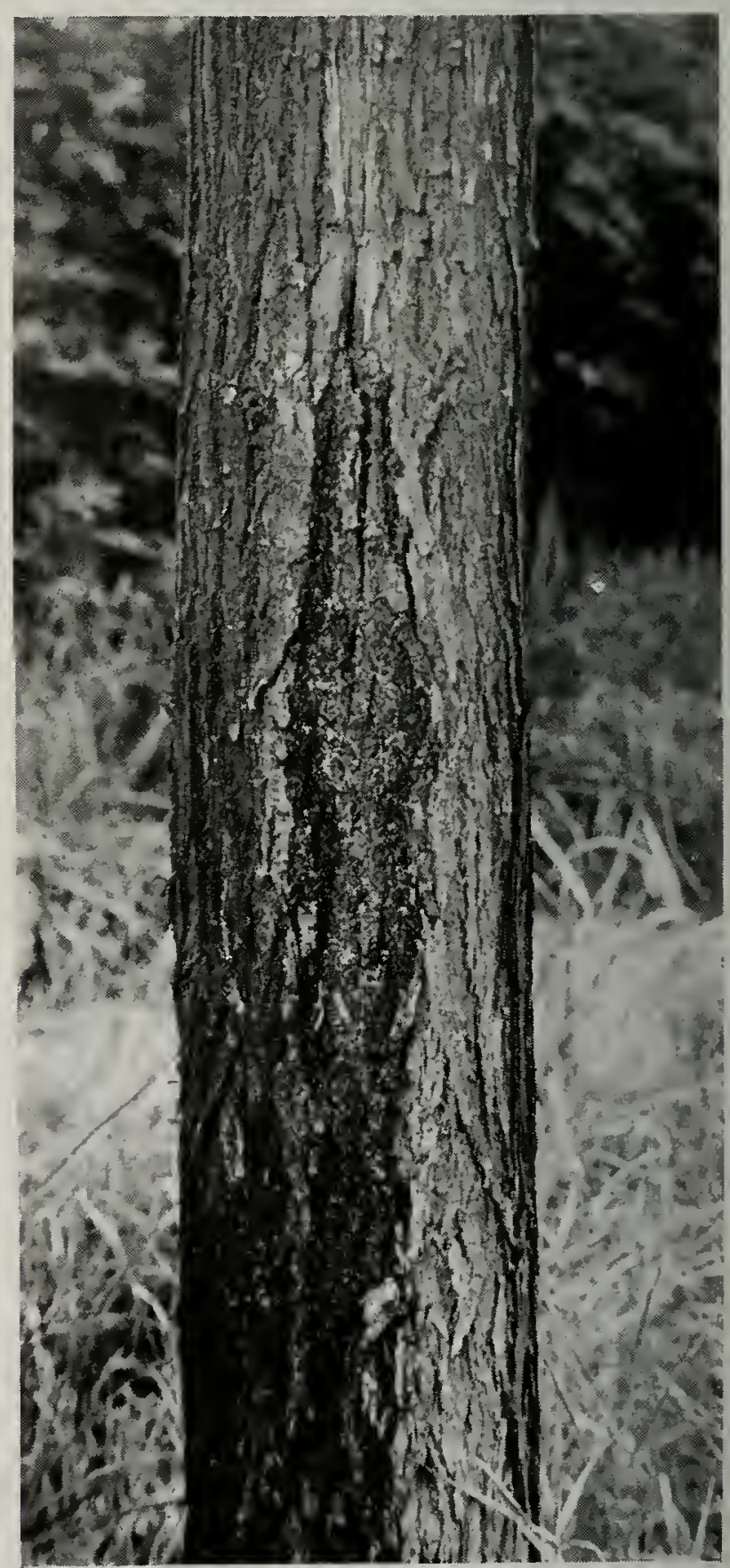

Fig. 6.-This elm is fluxing through a crack in the trunk, which originated as a frost crack during the preceding winter. Fluxing through the crack in the bark became apparent by June. 
through wounds made by the removal of branches, fig. 4 , through cracks in crotches, fig. 5, and trunks, fig. 6 , and through other trunk injuries. This exuding of sap is commonly called fluxing. The sap or flux as it oozes out of diseased wood is colorless to tan but turns dark upon exposure to air. When abundant bleeding occurs, the flux flows down the trunk, wetting and soaking large areas of bark, figs. 5 and 6 . When it dries, it leaves a light gray to white incrustation on the bark, fig. 7. Ogilvie (192t), who worked

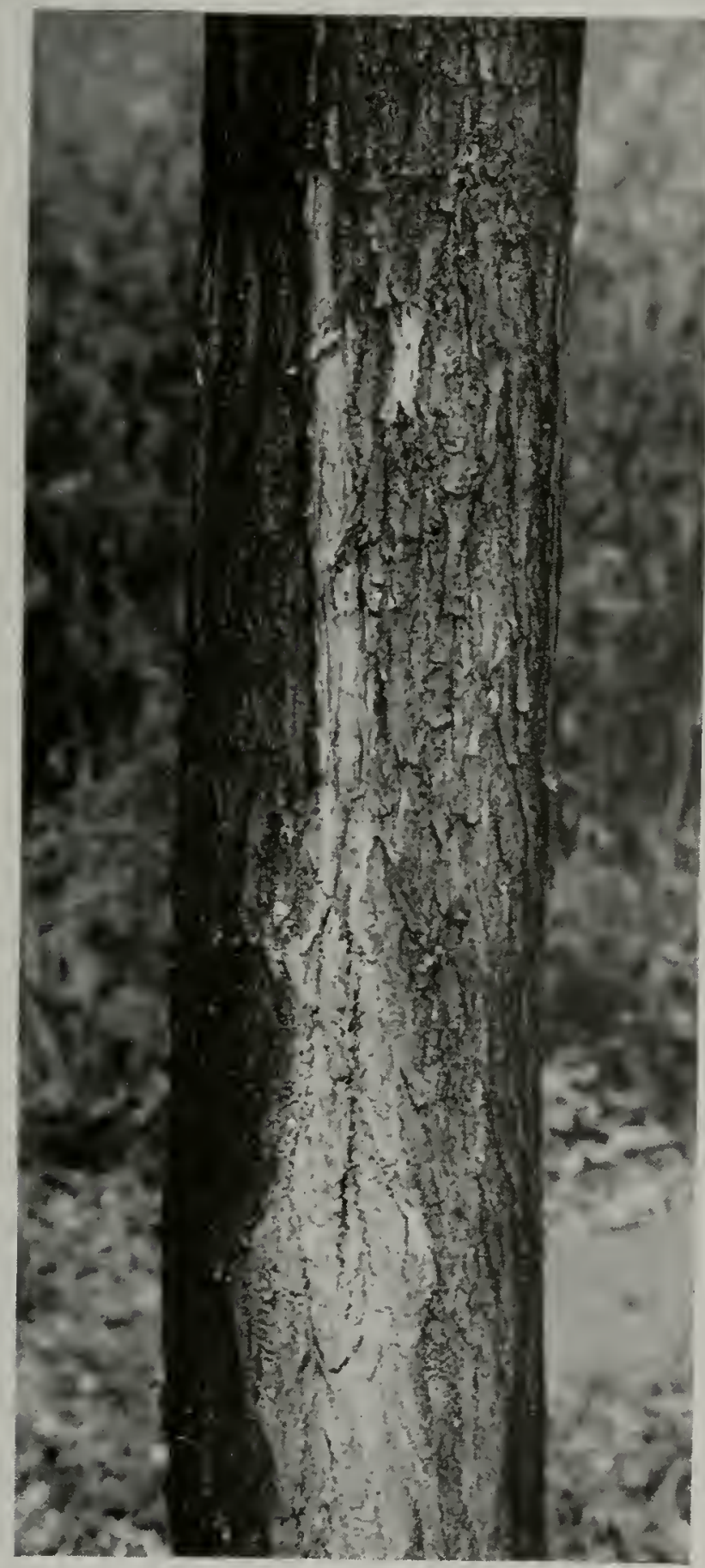

Fig. 7.-Dried flux showing on the bark of an elm after the trunk crack from which it came had closed.

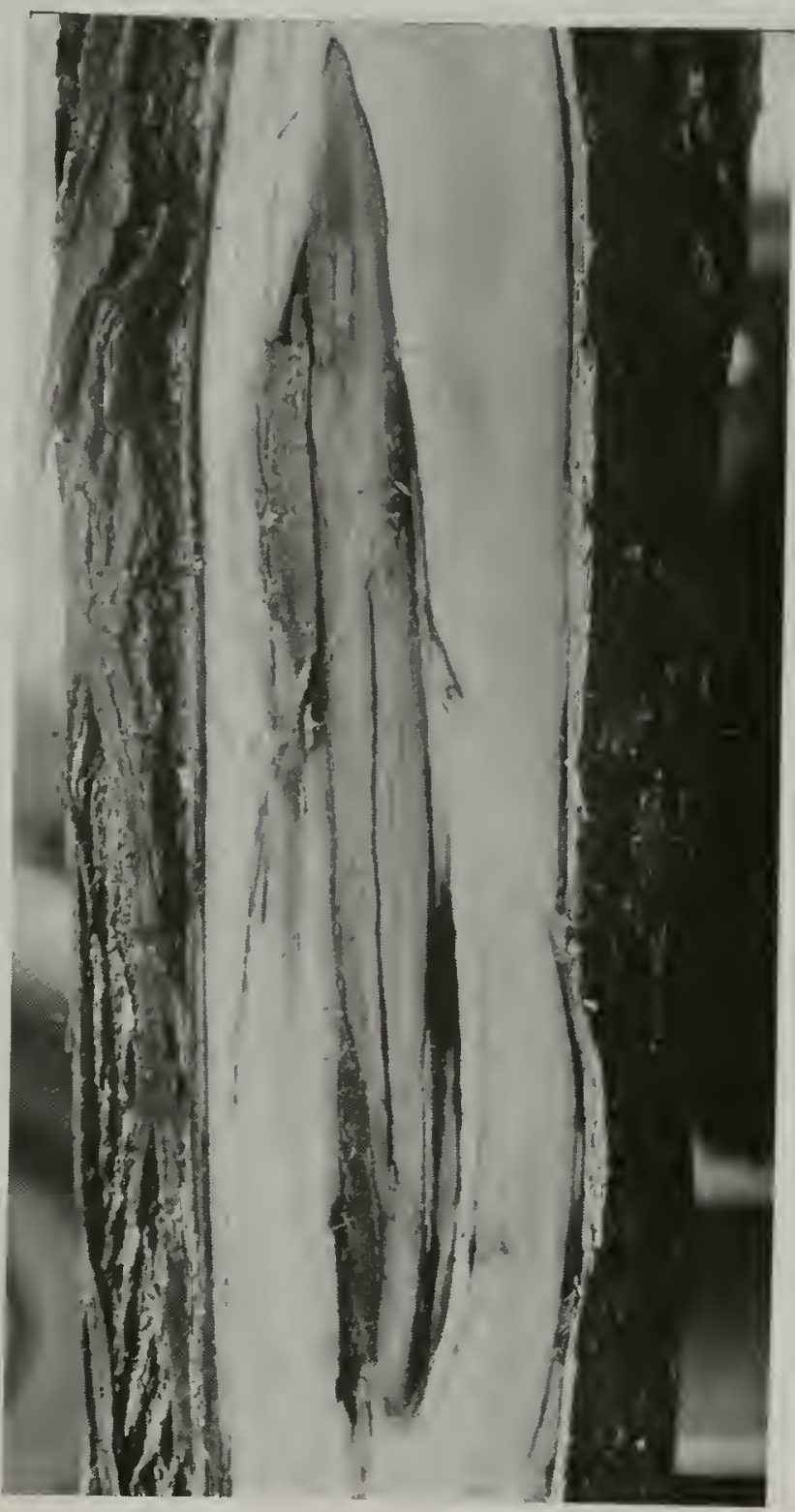

Fig. 8.-Crack in elm trunk wood around which a pocket formed between bark and wood. Such pockets develop when sap and gas seep out through cracks in the wood.

in England on elm and other trees, suggested that fluxing sap contains calcium carbonate and forms a white incrustation on the bark upon drying. In some cases, especially when fluxing is prolific or long continued, air-borne bacteria, yeasts and fungi contaminate the oozing sap, ferment it, and produce the malodorous material commonly called slime flux. Hence slime flux, in the common sense, is the material resulting from an entirely external putrefactive condition which develops only after bleeding has occurred.

The wetwood flux, when it exudes from the tree, is toxic to the extent that it is capable of retarding or preventing callus formation, and it frequently kills back the cambium at the base of a cut where a 


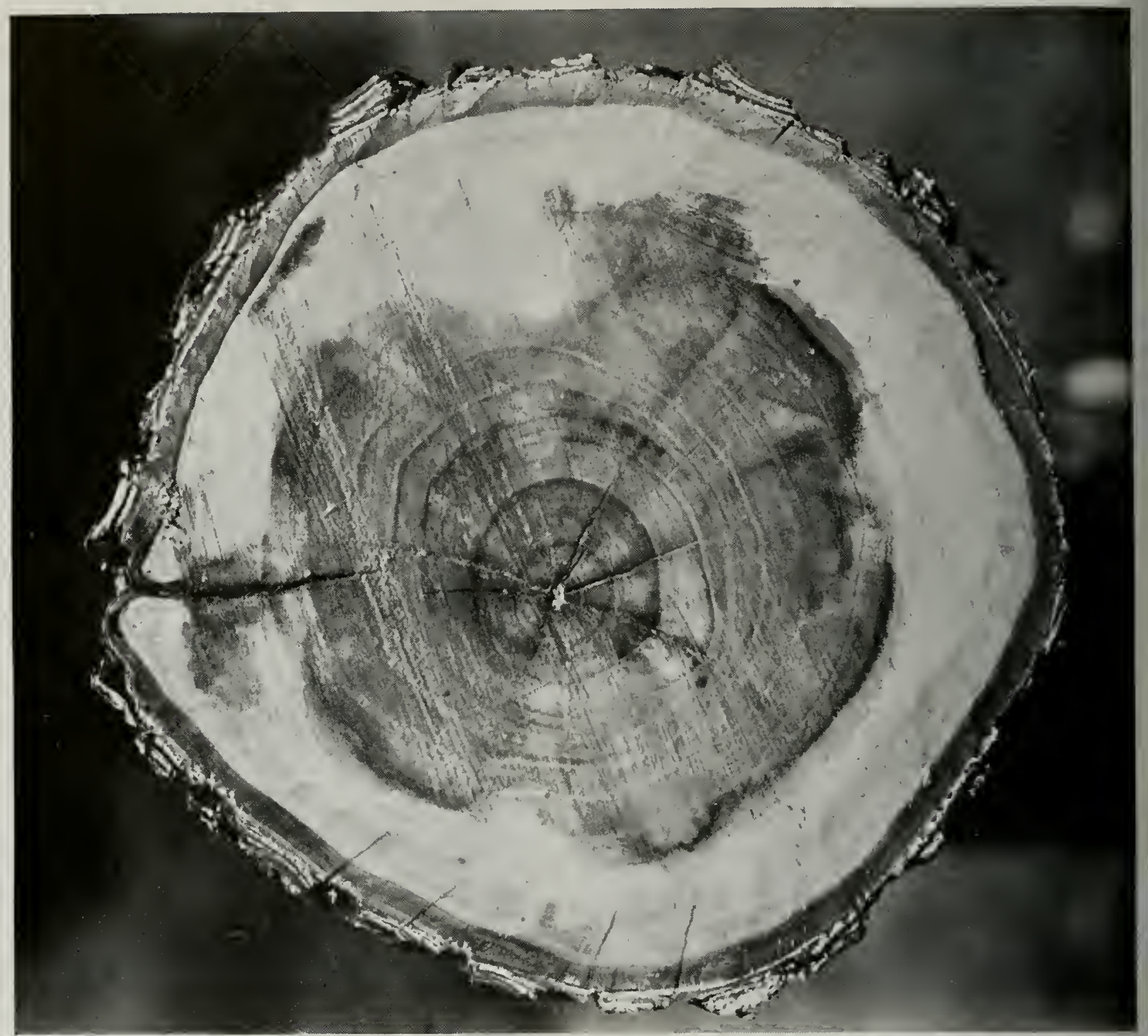

Fig. 9.-Cross section of trunk showing a crack that extends from wetwood-affected heartwood through the bark. Also visible are cracks radiating from the center of the heartwood. Cracks in the wood aid in spread of sap and gas in wetwood-affected trees.

branch has been removed, fig. $t$, and around trunk cracks through which it flows, fig. 8. Young shoots directly above fluxing regions may wilt. Foliage and young shoots, and also the grass at the base of an affected tree, may be killed if the flux drips on them.

At Hinsdale, in June and July of 1943, several affected elms having splits or cracks in the trunk bark were examined. Fluxing made the bark cracks on these trees conspicuous, fig. 6 . When the cracked bark was removed, corresponding cracks were found in the wood beneath, out of which sap had been oozing, fig. 8. Cross cuts of these trunks showed the cracks in the wood to extend inward into wetwoodaffected tissues, fig. 9. Cracks in the heartwood radiated from the center and extended through several woodrings, fig. 9. Most of these cracks did not reach the cambial region; therefore, they did not flux, although they may possibly have permitted more rapid and greater internal movement of sap and gas.

Cracks probably develop in the wood during the winter months, at times when the temperature falls rapidly to very low points. Toxic sap from the wetwoodaffected heartwood kills the cambium for some distance around the cracks in the wood. The bark separates from the wood forming oval to elongate pockets, fig. 8 . Cracks in the bark with flux oozing through them become apparent in June or July. Many such cracks callus over during the same growing season, fig. 10. In studying Platanus acerifolia Willd. which had developed frost cracks, Crandall (1943) found only wetwood-affected trees 


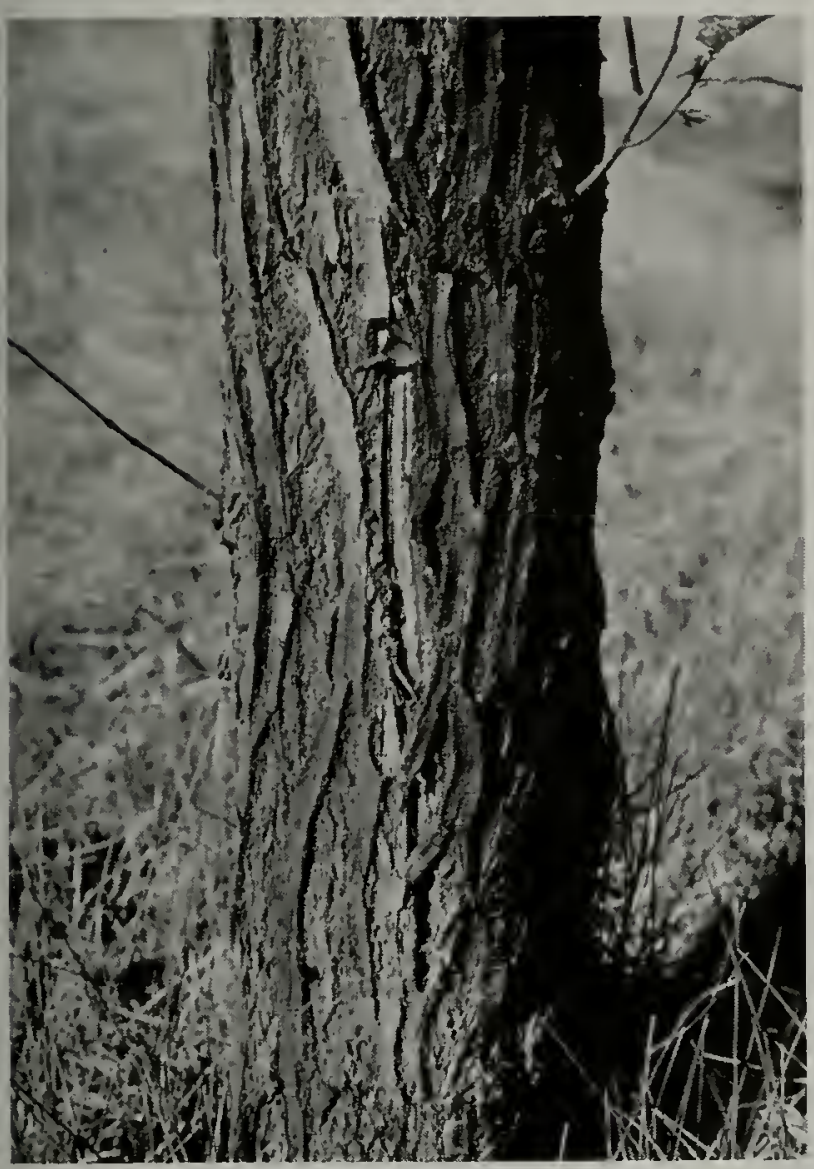

Fig. 10.-Callus formation that developed over a crack in the trunk of a wetwood-affected elm. The crack developed during the previous winter and flux became apparent during the spring and early summer.
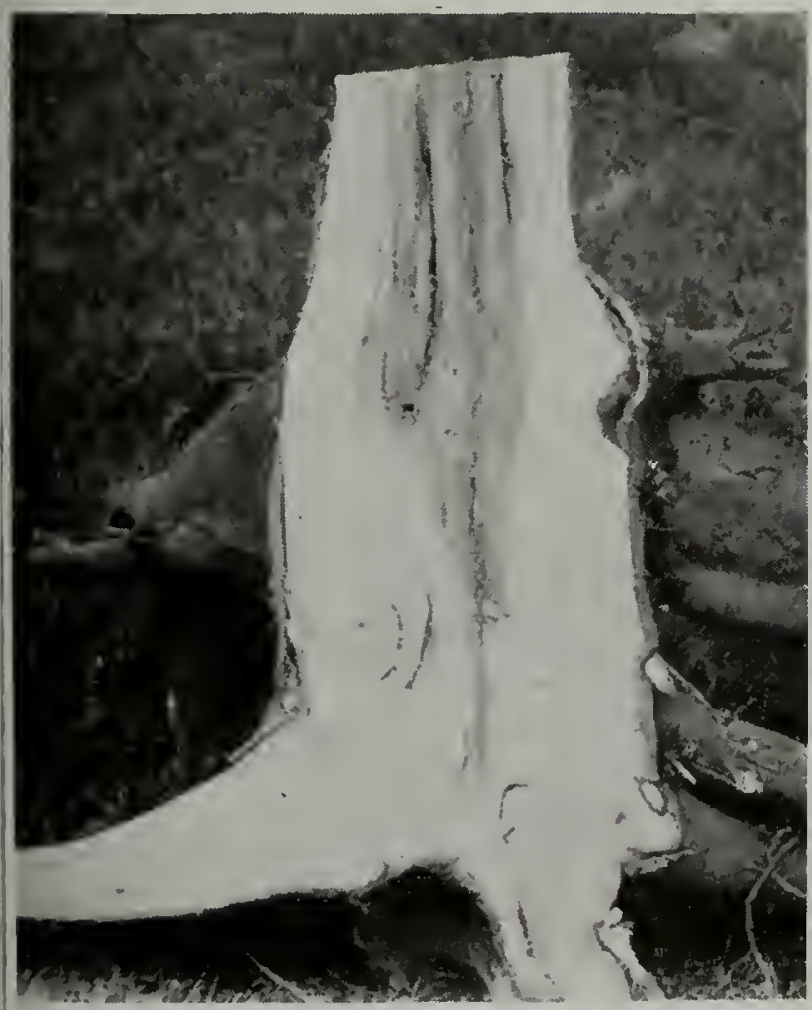

Fig. 11.-Split stump of a wetwood-affected Moline elm. Wetwood does not, as a rule, spread into roots of grafted elms but is confined mainly to the heartwood of the trunk. to show cracks. He observed that the sap from wetwood prevented callusing.

\section{Root Pathology}

Roots of affected trees usually show very little discoloration. However, in seed-
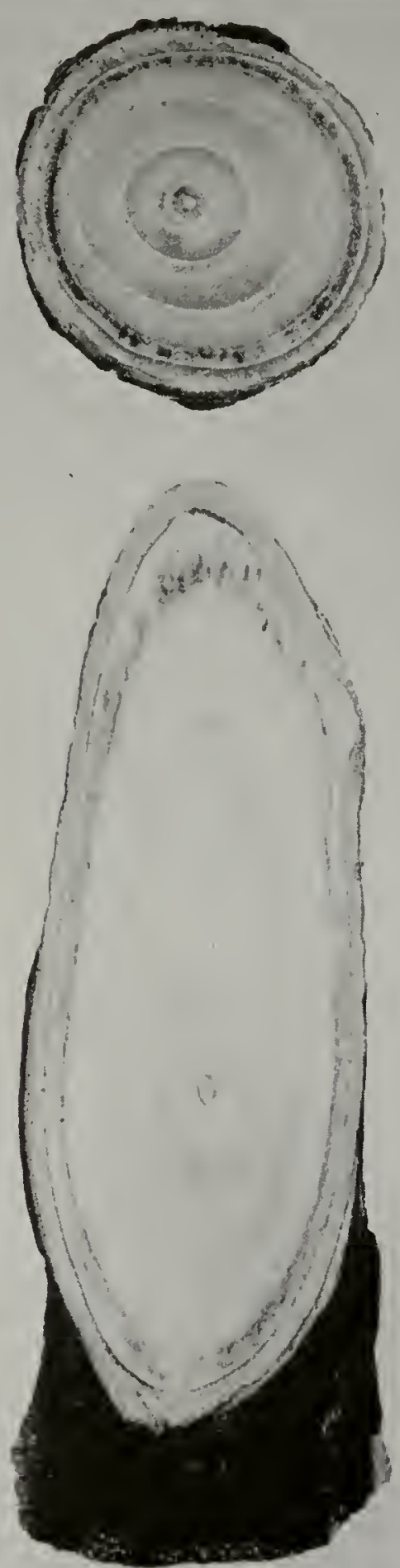

Fig. 12.- Sections of an elm branch that wilted because of wetwood. Grayish brown streaks form in the current-season wood, principally in the spring wood. When freshly cut, the discolored wood appears to be watersoaked. 
ling trees and in some grafted trees brown streaks may extend from the diseased trunk into the heartwood and occasionally into the sapwood of the roots. In most of the grafted trees examined, the brown discoloration was confined to the trunk rood above the region of grafting, fig. 11, with no evidence of disease in the roots of these trees.

\section{Branch Pathology}

Branches that wilt on wetwood-affected trees show, in the current-season wood,

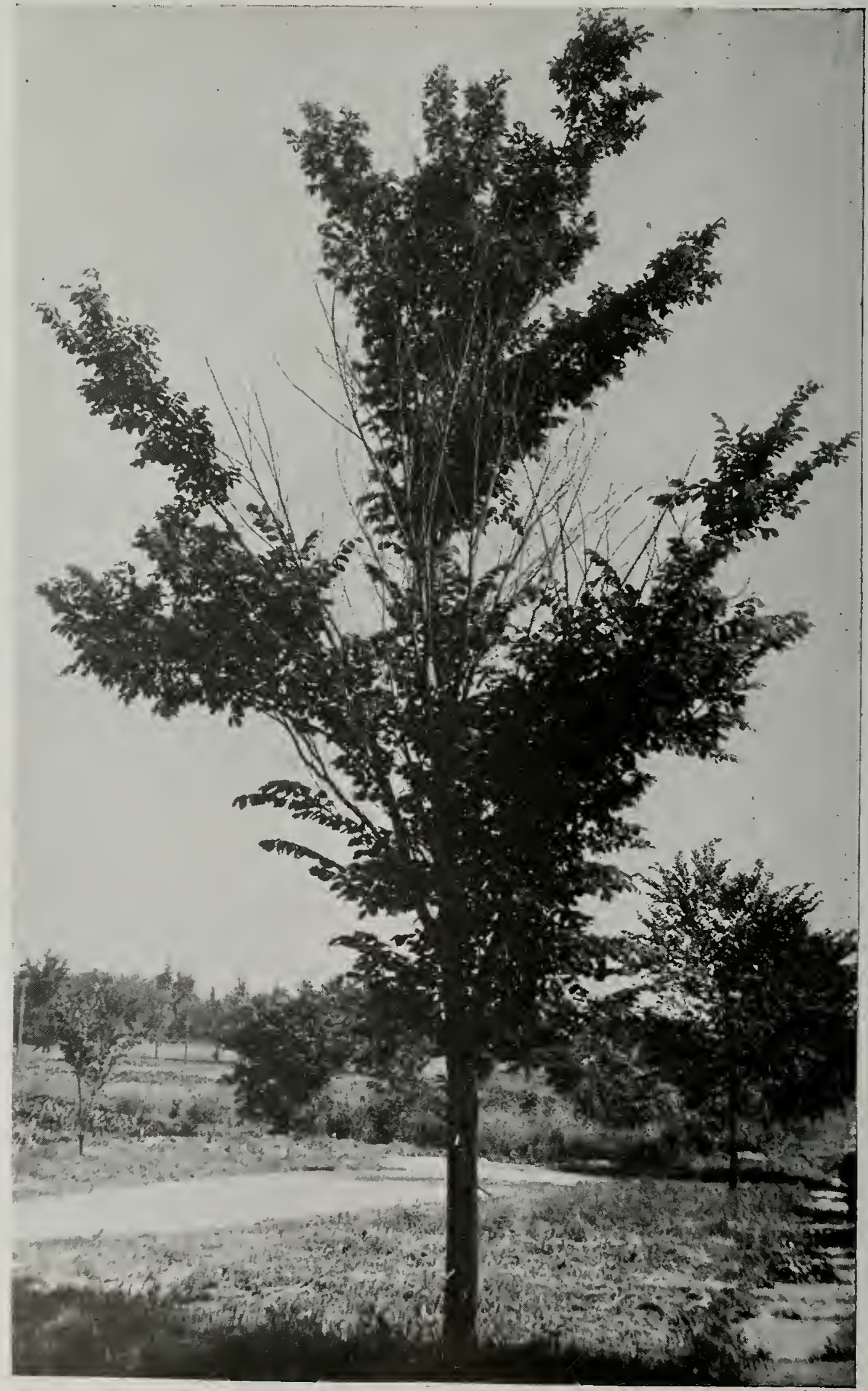

Fig. 13.-Branch dieback on a wetwood-affected elm on which wilting occurred several years in succession. 
grayish brown streaks that are especially noticeable in the spring wood, fig. 12 . These streaks originate in the trunk and spread out into the branches. However, they usually do not reach the branch tips. Where grayish brown streaks are abundant, they may appear as solid brown rings in the rvood of one or more seasons, but usually only in current-season wood, which usually appears water-soaked when freshly cut. Branches so affected may die, fig. 13. In some trees affected with wetwood, very few branches die. In others, scattered branches die, a few each year, and the

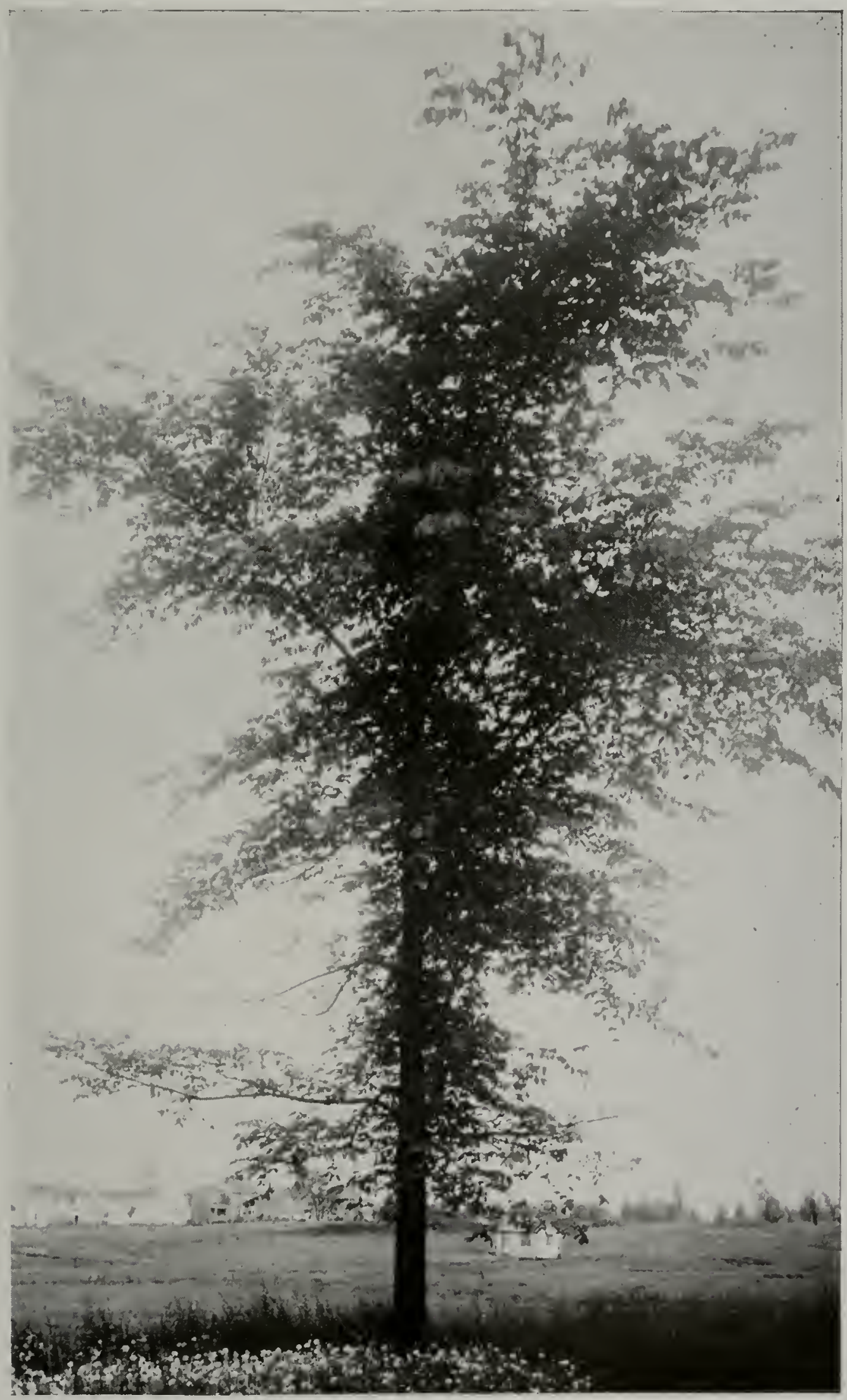

Fig. 14.-Wetwood-affected elm, which shows general decline, especially of lower branches. 
trees show gradual decline, as in the elm pictured in fig. 14.

Heartwood in the basal portions of some branches, especially large branches, is discolored brown, as in wetwood-affected appearance by the time they fall. Leaves that wilt slowly may turn yellow or brown before they fall. Many of the brown leaves may remain on the affected branches for several weeks. Leaves on some trees

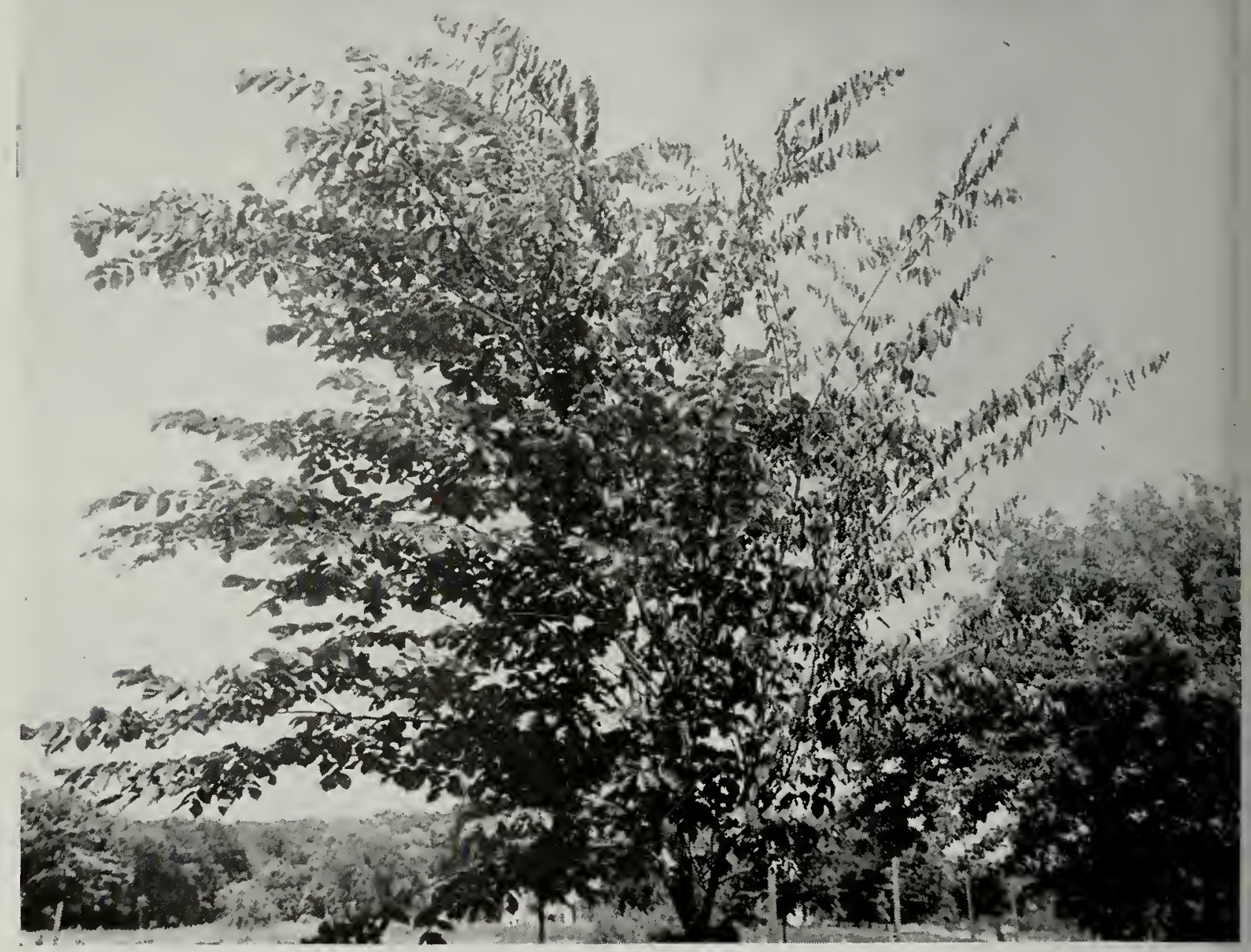

Fig. 15. - The wilt which occurs sometimes in elms affected with wetwood is evident on branches at right.

heartwood of the trunk shown in fig. 2 . This discoloration in branch heartwood is a continuation of the wetwood-affected heartwood in the trunk.

\section{Foliage Pathology}

Wilt occurs on elms affected with wetwood when sufficient quantities of the toxic sap that has accumulated in the trunk wood is carried into the branches. First, affected leaves curl upward along their margins, then the petioles become flaccid and finally the leaves droop. Curl and droop are followed by wilt, fig. 15 . Some leaves that wilt rapidly may drop from the trees while still green. Other leaves that wilt rapidly may take on a dull, greenish brown or somewhat bronzed may droop and turn yellow but not wilt, while those on others may turn dull greenish brown between the veins, fig. 16 . Many leaves that turn yellow or dull greenish brown may abscise prematurely during July and August.

Wilting as the result of wetwood in the trunk has been observed on trees as much as 10 inches d. b. h., but most frequently on trees 3 to 6 inches $d$. b. h. Elms more than 10 inches d. b. h. affected with wetwood usually do not wilt but frequently develop yellowing and browning of the foliage, followed by leaf drop and branch dieback. General decline may occur in these larger trees affected with wetwood.

Many large elms affected with wetwood are characterized by the dying, year after 


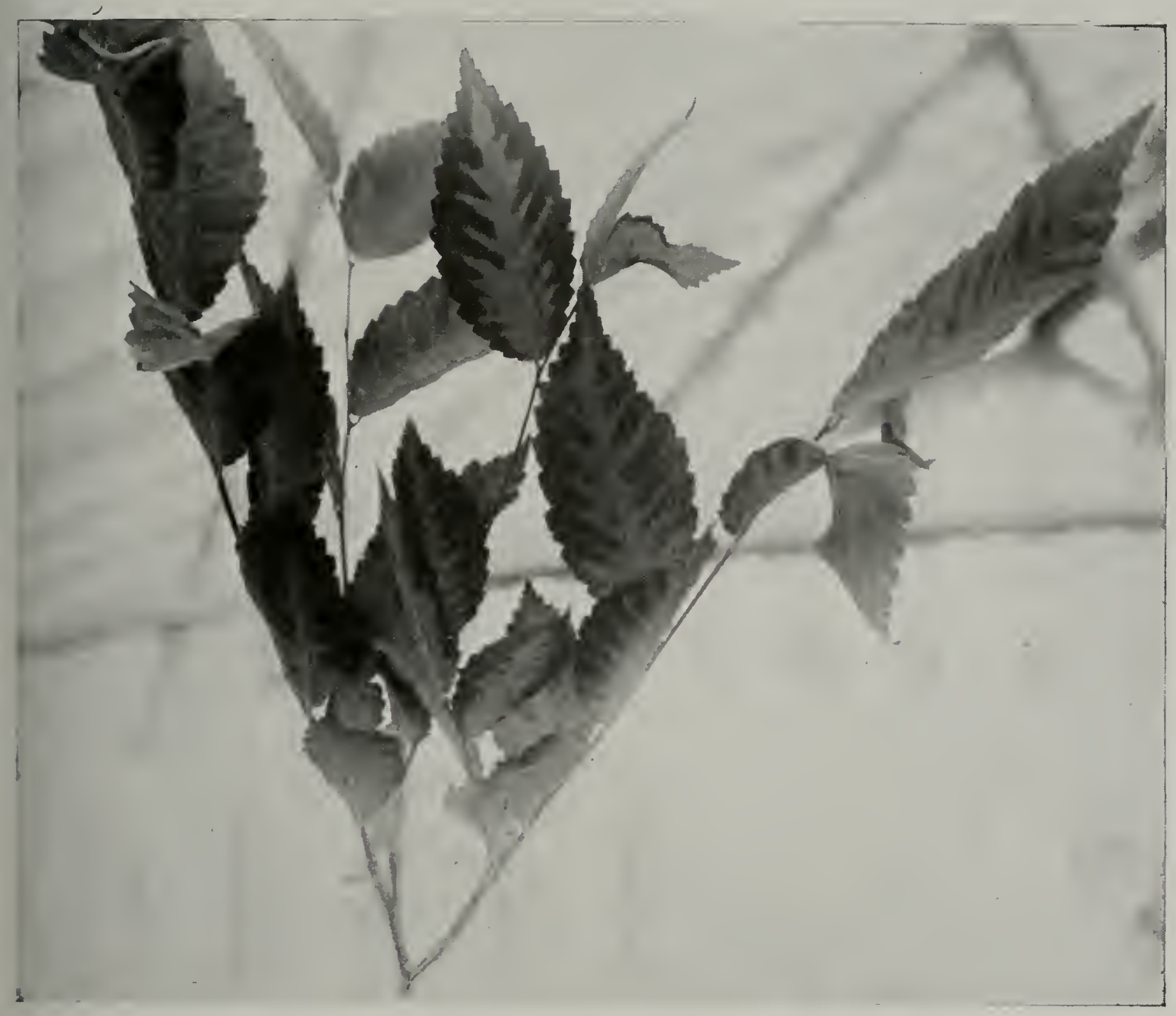

Fig. 16.-Leaf discoloration produced experimentally by injecting elm seedling with toxic sap from wetwood-affected elms. The toxic sap caused the leaves to turn dull greenish brown between the veins and along the margins.

year, of scattered branches. This type of branch dying is evident in the Hinsdale elm pictured in fig. 1 t.

\section{Dissected Elm}

An American elm, variety Littleford, that wilted during late July and early August of $19+3$ was cut up for examination. This tree had two trunk cracks near its base. Both cracks had developed during the previous winter and before the growth of $19+3$ wood. Both had fluxed earlier in the summer but were callused over by August. One crack, fig. 10, had a 12-inchlong bark callus which extended upward from a point 4 inches above the ground. The inner face of the bark and the wood callus which formed beneath the bark are shown in fig. 17. Fig. 18 shows the crack in the trunk wood after most of the 1943 wood adjacent to it had been chiseled off.
This trunk crack, approximately 18 inches long, extended into the 1938 wood.

The second trunk crack, fig. 9, was covered by a 2 -foot-long bark callus which extended upward from a point about 2 feet above the ground. 'This crack was directly beneath the branches which wilted in the upper part of the tree. Wood callus had developed only in the $19+3$ woodring of the crack. A cross section of the trunk through the crack, fig. 9, shows wetwoodaffected heartwood, which includes most of the $19+1$ and 1940 woodrings and all older woodrings. Sap which had spread out through the crack from the infected wood into the $19+2$ woodring and the spring wood of the $19+3$ ring was carried from the crack up the trunk through 1943 spring wood and into the branches, which soon wilted. There was some lateral spread of the sap as it traveled up the trunk. The sap caused brown streaks to form in the 


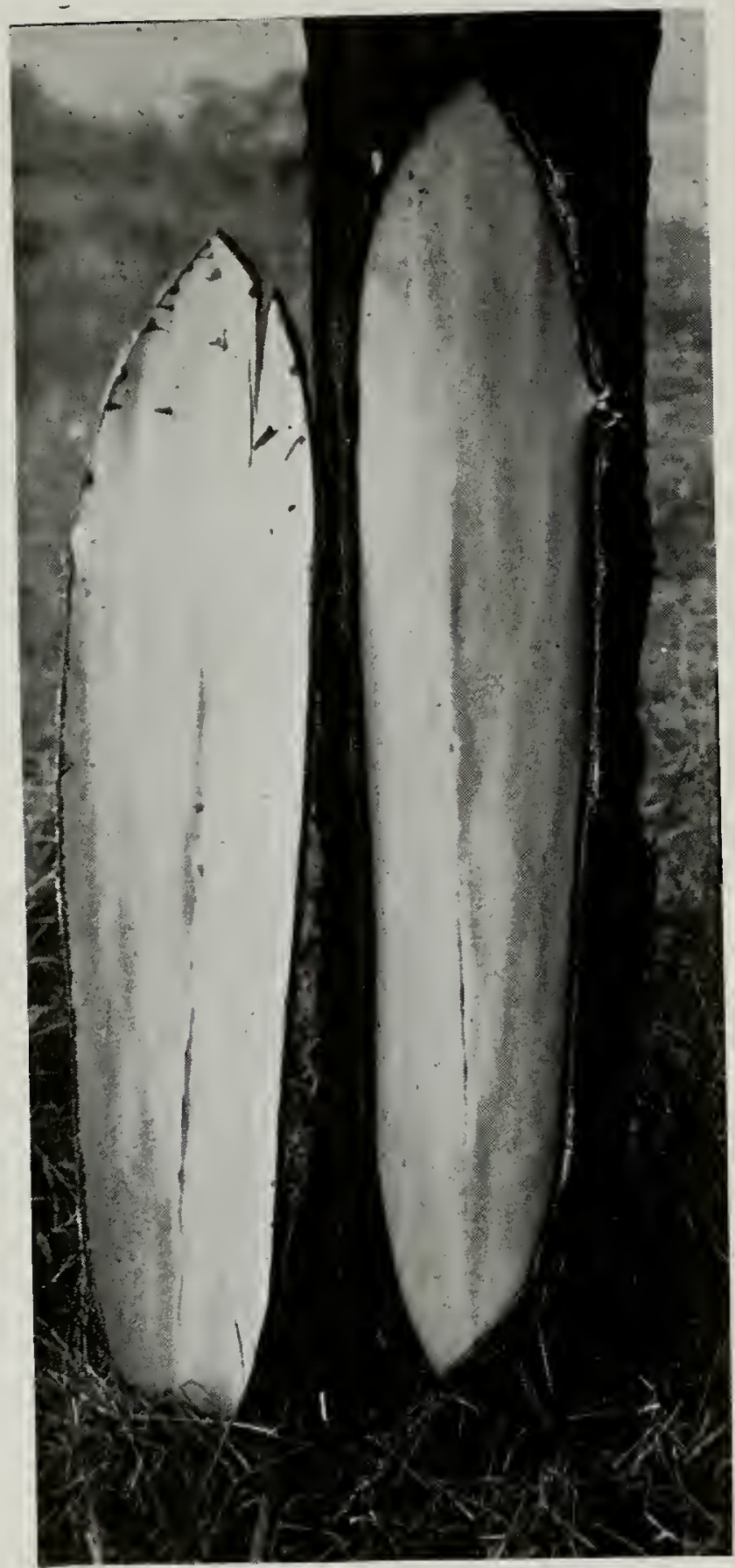

Fig. 17.-A wetwood-affected elm with a trunk crack which had callused over. Callus was formed by both the wood and bark.

$19+3$ spring wood through which it passed. However, the streaks in the branches did not extend to the branch tips. Other cracks, which were confined within the heartwood, are shown radiating out from the center of the trunk in fig. 9. The sap in this tree was under a pressure of 13.5 pounds before the tree was cut. Wetwoodaffected tissue extended only to the junction of roots and trunk, fig. 11.

\section{Isolations}

Samples from 346 elms-American, Moline, Littleford, slippery, English and
Siberian-were cultured in the laboratory, 1939-1943. Several types of bacteria were isolated from 239, or approximately 69 per cent, of the trees sampled. Of the 346 trees, 292 had wilted during one or more growing seasons. Many of the remaining 54 trees, which were affected with wetwood but which had not wilted, showed flux. As preliminary tests showed that the various bacterial isolates would grow abundantly in nutrient broth and on potato dextrose agar, these two media were used throughout this investigation, except where otherwise stated.

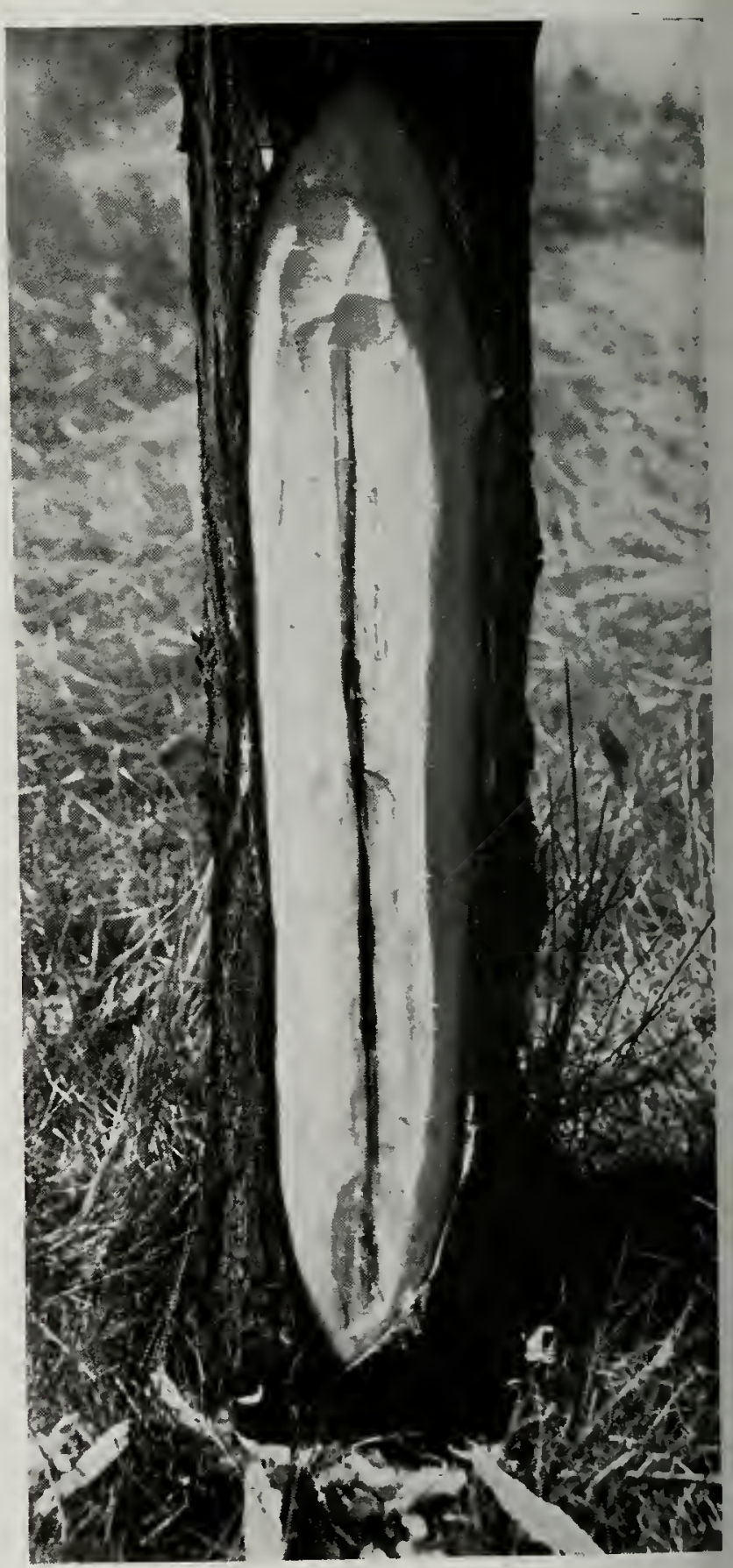

Fig. 18.-The trunk crack shown in fig. 17 with the current-season wood removed. Grayish brown discoloration formed in the wood along the crack. 
Table 1.-Summary of isolations obtained from $346 \mathrm{elms}$ which showed wetwood.

\begin{tabular}{|c|c|c|c|c|}
\hline Material Sampled & $\begin{array}{c}\text { Portion of Tree } \\
\text { Cultured }\end{array}$ & $\begin{array}{l}\text { Number of } \\
\text { Samples } \\
\text { Cultured }\end{array}$ & \begin{tabular}{|c|} 
NuMber of \\
SAMPLES \\
From Which \\
Bacteria \\
WERE IsOlated
\end{tabular} & $\begin{array}{c}\text { Per Cent of } \\
\text { SaMples } \\
\text { From Which } \\
\text { Bacteria } \\
\text { WERE Isolated }\end{array}$ \\
\hline Branch........ & $\begin{array}{l}\text { Sapwood ........... } \\
\text { Heartwood ...... }\end{array}$ & $\begin{array}{r}261 \\
22\end{array}$ & $\begin{array}{l}95 \\
14\end{array}$ & $\begin{array}{l}36.40 \\
63.64\end{array}$ \\
\hline Trunk... & $\begin{array}{l}\text { Sapwood ........ } \\
\text { Heartwood...... } \\
\text { Cambial region... } \\
\text { Phloem ........ }\end{array}$ & $\begin{array}{r}232 \\
30 \\
6 \\
3\end{array}$ & $\begin{array}{r}181 \\
28 \\
0 \\
1\end{array}$ & $\begin{array}{r}78.02 \\
93.33 \\
0.00 \\
33.33\end{array}$ \\
\hline Sap from trunk. & Sap. . & 23 & 23 & 100.00 \\
\hline
\end{tabular}

In all of the branch and trunk samples cultured, the diseased condition was indicated by brown streaks or other abnormal brown discoloration. The number and type of samples cultured, the number of bacterial isolates obtained and the per cent of samples from which bacteria were isolated are given in table 1.

The types of materials samples, listed in table 1, were branch sapwood and heartwood, trunk sapwood, heartwood and phloem, and sap from wetwood-affected trunk wood. Isolates of bacteria were obtained more frequently from heartwood than from sapwood and from a greater per cent of the trunk samples, approximately 77 per cent, than of the branch samples, approximately 39 per cent. Bacteria were present in all sap samples tested, indicating that sap of wetwoodaffected trunk wood is constantly infested with bacteria. These data indicate that bacteria are more abundant in the trunk wood, where they live over from year to year, than in the brown discolored branch wood. Crandall (1943) found that, in Platanus acerifolia Willd., fermenting bacteria were limited mainly to the innermost rings, and he concluded that these bacteria usually did not readily attack the healthy tissues of well-established trees.

\section{Histology}

Histological studies were made on tissues from 11 elms affected with wetwood. The tissues examined included branch xylem, root xylem, trunk xylem, trunk cambium and trunk phloem. Many vessels affected with wetwood, especially those of the trunk xylem, contained tyloses, bacteria and gumlike materials. Some vessels, fig. 19, were filled with large, thin-walled tyloses while others had small tyloses which covered only the inner vessel walls. Tyloses were formed by August in current-season wood of wetwood-affected elms which wilted during July. They appeared to be sufficiently abundant in some vessels to retard and possibly prevent the flow of sap.

Masses of bacteria were present in scattered vessels and ray cells. Bacteria were more abundant in trunk xylem than in branch xylem. The limited occurrence of bacteria in the branch xylem explained why they were not isolated so frequently from branch samples as from trunk samples. There was no evidence of tissue disintegration in the infected wood.

Light brown deposits of what appeared to be gum were observed in a few scattered vessels and ray cells. Occasionally cells appeared to be filled with this gum, but most frequently the gum appeared to be deposited on the cell walls. Ogilvie (1924) reported medullary rays and wood parenchyma of water-soaked elm wood to be filled with a gummy substance, composed partly of tannin and partly of starch, that gave the wood a brown color.

Fungi were not found in any of the wetwood-affected tissues that were examined.

The formation of callus over a trunk incision on a 2-year-old elm seedling submerged in water occurred within 11 days. The callus tissues were laid down by xylem, cambium and phloem. That no callus formed over a trunk incision of 


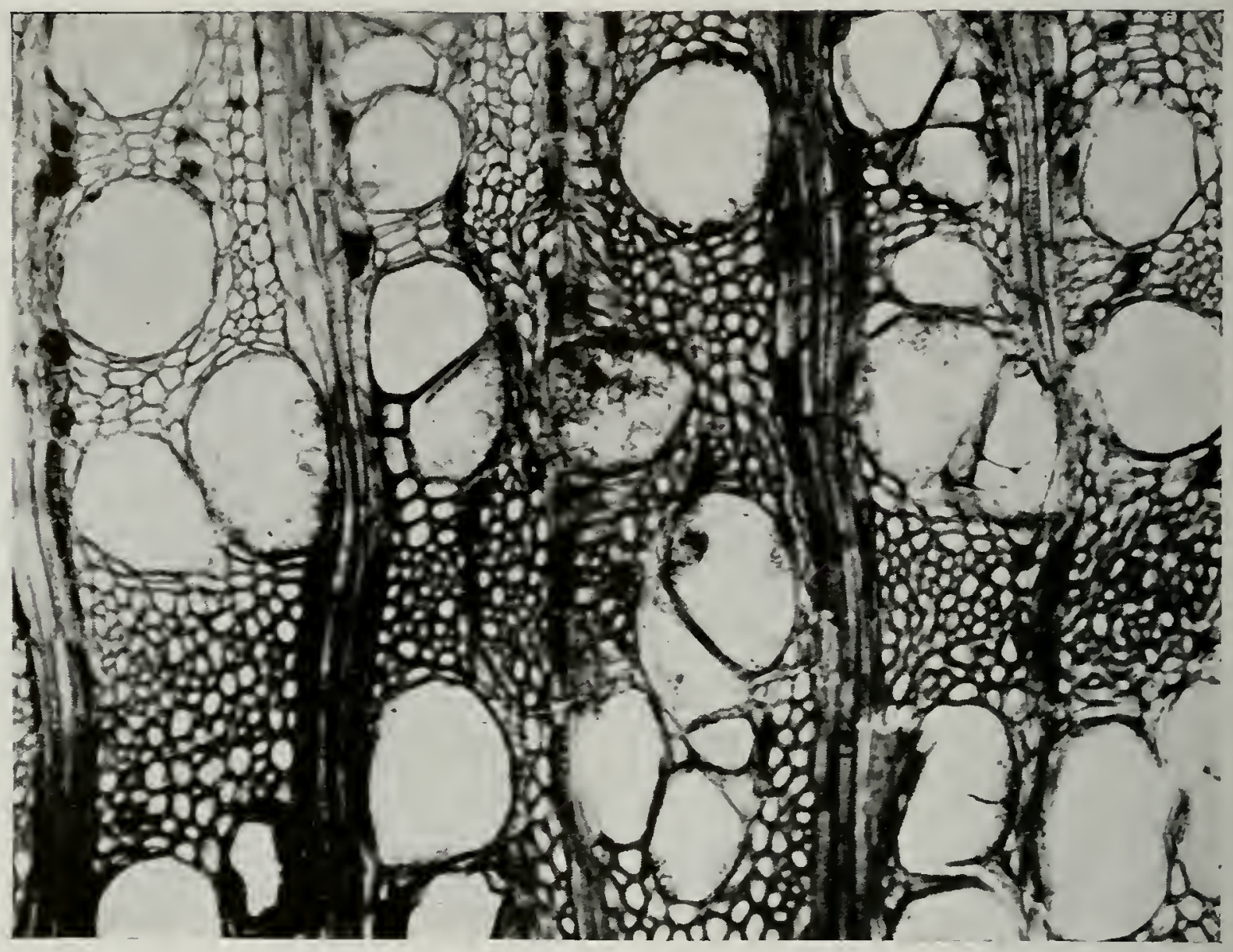

Fig. 19.-Cross section of xylem of elm affected with wetwood, showing tyloses in many vessels. Bacteria are occasionally present in some of the vessels. They are observed most frequently where tyloses are abundant. $\times 130$.

a second 2-year-old seedling when the cut portion of the stem was submerged in sap from a diseased elm indicates that such sap prevents or at least retards the formation of callus. Many of the ray and parenchyma cells near the surface of the trunk incision which was submerged, in sap became filled with brown, gumlike material.

\section{The Wetwood Organism}

Five bacterial isolates, representative of the numerous isolates obtained from elms affected with wetwood, each obtained from a different elm, were studied for their morphology, cultural characters and biochemical reactions. Isolates $1,3,+$ and 5 were obtained from wetwood-affected elms which had wilted. Isolate 2 was obtained from a wetwood-affected elm which had not wilted. Isolates 1, 2 and $t$ were from parkway trees, while isolates 3 and 5 were from nursery trees.

Morphology.-These five isolates are believed to represent a single species of bacterium. The organism is a short rod with rounded ends and occurs singly or, rarely, in pairs or chains, fig. 20. Cultures on potato dextrose agar ( $\mathrm{pH} 6.8$ ) incubated at $2+$ degrees $\mathrm{C}$. for +8 hours produced cells measuring $0.68-2.00 \times 0.3+-0.68 \mu$ mostly $0.68-1.35 \times 0.3+-0.68 \mu$. This organism is Gram-negative, motile, not acidfast, and has up to six peritrichiate flagella measuring up to $11 \mu$ long, fig. 21. Capsules and spores were not observed.

Cultural Characters.-Growth in nutrient broth appears in $2+$ hours or less and the broth becomes strongly clouded or turbid, with a decided kidney bean odor. The organism usually forms a thin pellicle or flocculent surface growth when undisturbed. Sediment is usually scant and viscid but becomes abundant if cultures are disturbed at frequent intervals. The medium becomes strongly alkaline. Colonies on potato dextrose agar incubated at $2 t$ degrees C. for $2 t$ hours are circular, smooth, entire, flat to slightly raised, and usually opaque (whitish cream) but occasionally somewhat translucent. Growth in streaks on potato dextrose agar is abundant, spreading, glisten- 


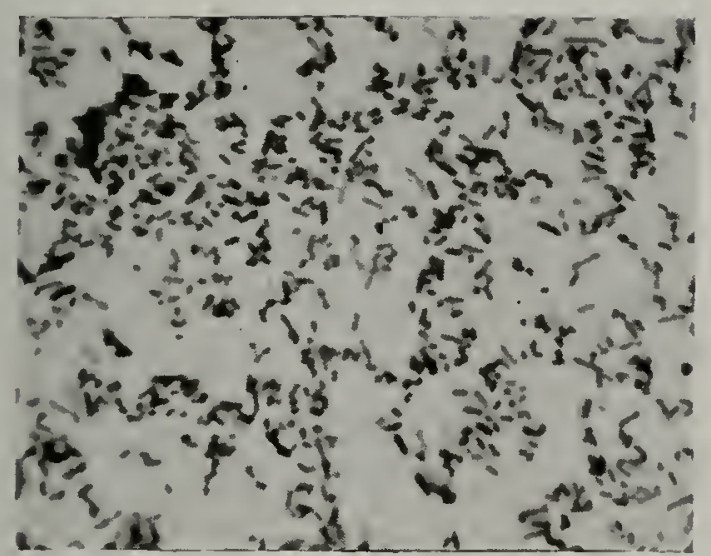

Fig. 20.-The organism that causes wetwood of elm produces cells that are short rods with rounded ends and that occur singly or, rarely, in pairs or chains. $\times 1,000$.

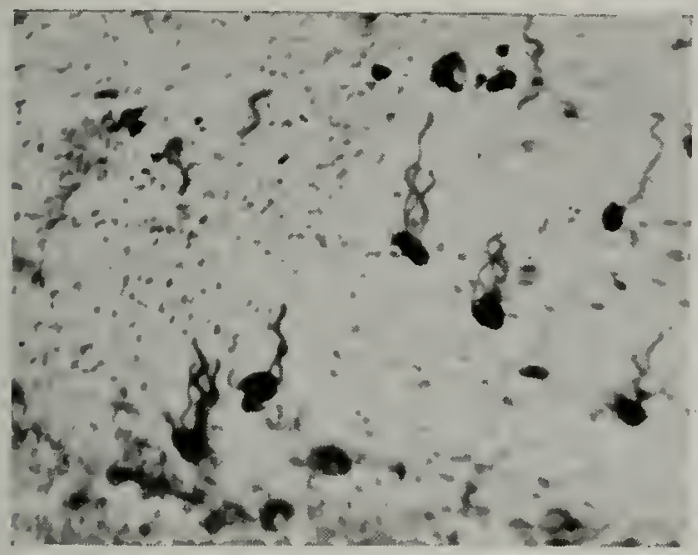

Fig. 21.-Cells of the wetwood organism have peritrichiate flagella. $\times 1,500$.

ing, whitish cream and viscid, and is accompanied by an odor of fermentation. A culture of the organism growing on cabbage infusion agar is shown in fig. 22 . Growth in stabs in potato dextrose agar is abundant and is accompanied by the liberation of gas. This gas produces fissures and frequently forces a portion of the agar up against the cotton plug or beyond the mouth of the test tube. At first the colonies are lens shaped to disk shaped. The medium remains unchanged in color. In shake cultures of potato dextrose agar covered with a mixture of paraffin and vaseline, the organism develops abundant growth through the medium and produces sufficient gas within 20 hours to form fissures in the medium and to start raising the paraffin-vaseline seal. Growth on additional agars is as follows: abundant on cabbage infusion; moderate on lima bean and wood decoction ; scanty on bean pod, nutrient broth,

* Wood decortion agar was made by adding 2 per cent agar to distilled water in which normal elm wood had been soaked for several days. corn meal, malt extract, prune, and plain agar plus 1 per cent, 5 per cent and 10 per cent dextrose; hardly visible on wort agar and on plain agar plus 20 per cent dextrose. No visible growth develops on 2 per cent plain agar. Streak cultures on potato plugs produce an abundant, filiform, glistening, dark gray growth that darkens the potato tissue only slightly. The texture of the potato tissue is not visibly affected. Streaks on carrot plugs produce scant growth, consisting of one to a few beadlike glistening cream colonies. Carrot tissue is not visibly affected. No growth develops from streaks on apple plugs. Milk is coagulated in $2+$ hours at 37 degrees $C$. and in 13 days at $2+$ degrees C. There is a separation of acid curd with the production of whey. The milk changes to $\mathrm{pH} 4.1-5.1$ by the end of 15 days. Litmus and bromocresol purple are reduced. Milk is not peptonized. By Conn's

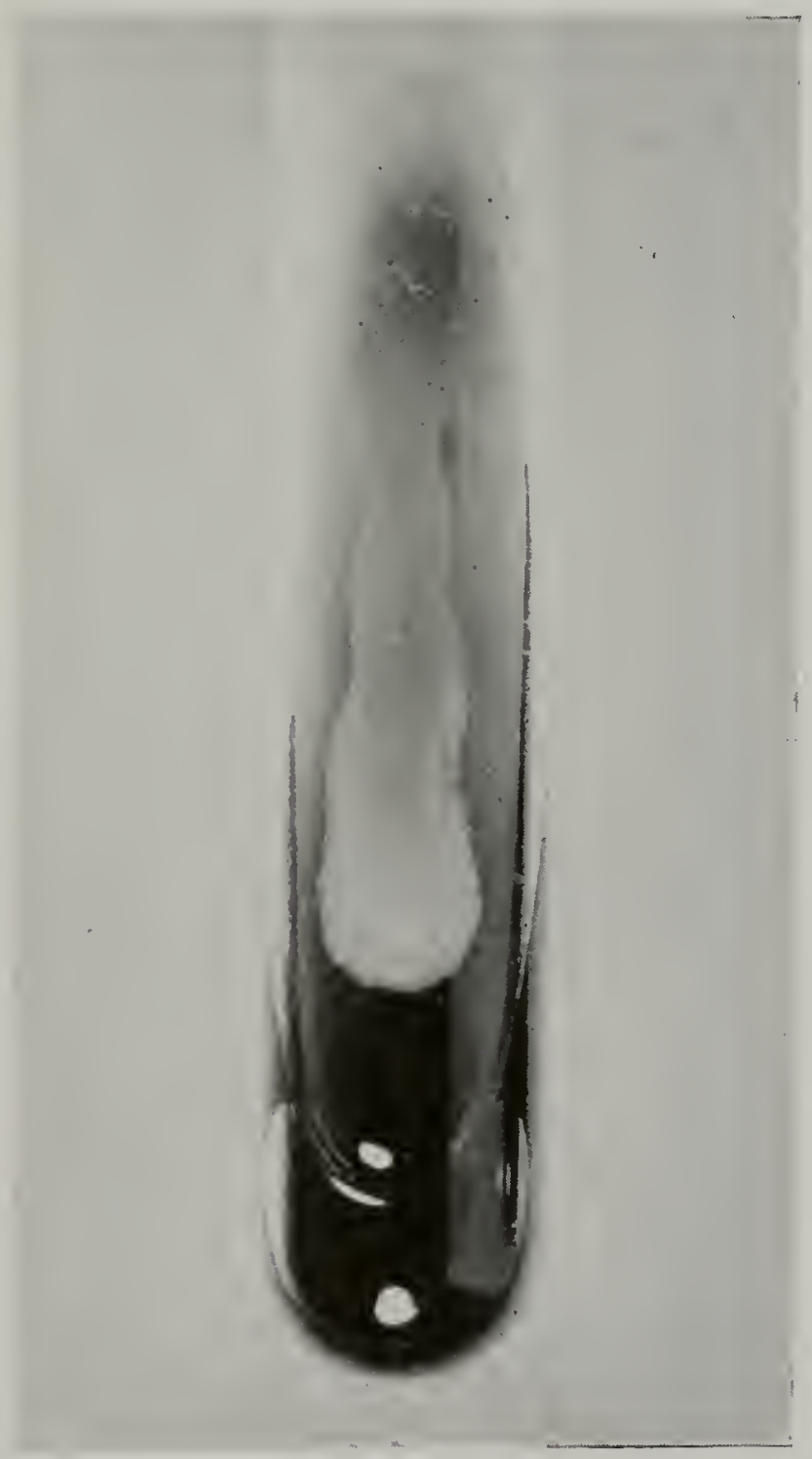

Fig. 22.-Culture of the wetwood organism growing on cabbage infusion agar. 
method of rennet production (Society of American Bacteriologists, Committee on Bacteriological Technic, 1939), whey and hard curd are produced in 20 minutes by isolate 4 , in 18 hours by isolate 2 and in 40 hours by isolates 1,3 and 5 . In shake cultures, each isolate grows throughout the agar. The least amount of growth develops in the upper quarter inch of medium. On agar in Petri dishes, each isolate grows beneath and beyond both microscope slides and Petri dish bottoms placed on the surface of the medium.

The optimum temperature for growth of the organism is approximately 24 to 30 degrees C., maximum about 37 degrees C. and minimum 5 degrees $C$. or lower. Potato dextrose agar slant and shake cultures held at -12 degrees $C$. for 4 days, then incubated at 24 degrees C., produce abundant growth within 3 days, with conspicuous gas production in the shake cultures. The thermal death points for the five isolates are 15 minutes at 55 degrees C. for isolates 1,3 and $5 ; 10$ minutes at 55 degrees $C$. for isolate 2 and 10 minutes at 45 degrees $C$. for isolate 4. The optimum $\mathrm{pH}$ range for growth is $6.82-7.50$, the maximum is $\mathrm{pH} 10.00+$ and the minimum is $\mathrm{pH} 4.67$.

Biochemical Reaction.-Growth of the organism in gelatin stabs is beaded and most abundant at or near the surface but absent beyond $15 \mathrm{~mm}$. below the surface. There is no liquefaction and the medium is unchanged. Colonies on gelatin are punctiform, convex, entire, smooth and translucent. Nitrates are reduced to nitrites without the formation of gas. Indole is not formed. Hydrogen sultide is produced. Asparagin stimulates growth without the production of gas in synthetic peptone-free medium (Society of American Bacteriologists, Committee on Bacteriological Technic, 1939). The medium becomes alkaline. Starch is not hydrolyzed. Both the methyl red and Voges-Proskauer tests are positive. Pectin is not fermented by the method described by Elrod (1942).

All fermentation tests to determine the sources of carbon that these five isolates utilize were run in duplicate and in parallel series on nutrient broth and synthetic peptone-free basic media. Both types of basic media were used, since Burkholder (1932) has pointed out that accurate results in carbohydrate fermen- tation tests frequently are not obtained when strong alkali-producing bacteria are grown in beef-extract-peptone broth. One per cent of each carbon was used except for trehalose, melibiose and cellobiose, where 0.5 per cent was used. These isolates produced both acid and gas from arabinose, rhamnose, xylose, dextrose, fructose, galactose, mannose, lactose, maltose, trehalose, melibiose, cellobiose, mannitol, sorbitol and salicin. They produced slight acid and gas from starch, slight acid but no gas from glycerol in nutrient broth, alkali and no gas from glycerol in synthetic peptone-free medium, and no acid or gas from inulin, dextrin or filter paper. Acid and gas were not produced by these isolates from elm sawdust in nutrient broth or from elm sawdust in synthetic peptone-free medium when the medium was autoclaved after the sawdust was added. However, there was slight acid and no gas production in the synthetic peptone-free medium when the elm sawdust was autoclaved before it was added to the sterile medium. Variable results were obtained with sucrose, raffinose, melezitose and dulcitol. Isolates 1,3 and 5 produced alkaline reaction, without the formation of gas, from all four carbons. Isolate 2 produced acid and gas from sucrose and raffinose and an alkaline reaction without gas from melezitose and dulcitol. Isolate 4 produced both acid and gas from all four carbons. Variation in ability of these five isolates to ferment sucrose, raffinose, melezitose and dulcitol is not believed to be sufficiently significant to separate them as distinct species.

\section{Taxonomy}

The organism constantly associated with wetwood of elm in Illinois is similar in many respects to Erwinia salicis Day. However, it reacts differently from $E$. salicis by producing gas from most of the sources of carbon that were tested. In addition, it changes litmus milk, produces hydrogen sulfide and does not produce a bright yellow pigment on potato. Also, it is similar in many respects to Pseudomonas lignicola Westerdijk \& Buisman (1929), which inhabits the wood of elms in Holland. However, it differs from $P$. lignicola as follows. It produces gas from dextrose and most other sources of carbon tested, 
whereas $P$. lignicola does not produce gas from glucose, the only source of carbon tested by Westerdijk \& Buisman. In addition, it has peritrichiate, not polar, flagella, coagulates litmus milk with the production of acid, reduces nitrates, and does not hydrolyze starch. Because of these differences, as well as because of the complex type of disease it produces in elms, the wetwood organism is believed to be a new species and is so described below. It is associated with the production of wetwood, wilt, dieback, premature leaf drop and flux of elm-American, Littleford, Moline, slippery, English and Siberian. Affected trees flux through trunk wood exposed by the removal of branches, through cracks in crotches, cracks in trunks, and other types of injuries that penetrate to wetwood-affected tissues. The organism inhabits mainly heartwood and inner sapwood and is especially likely to invade elms through pruning wounds, crotch injuries and wounds made during surgical treatment, transplanting and cultivation in the nursery. The wetwood organism was isolated from dark brown diseased trunk sapwood and heartwood and occasionally from brown-streaked branch wood.

\section{Erwinia nimipressuralis* New Species}

The organism is a short rod with rounded ends, $0.68-2.00 \times 0.34-0.68 \mu$, mostly $0.68-1.35$ $\times 0.3+-0.68 \mu$, arranged singly or, rarely, in pairs or chains; motile, with up to six peritrichiate Hagella; capsules and spores not observed; anaerobic, Gram-negative and not acid-fast.

On potato dextrose agar, colonies are circular, smooth, entire, flat to slightly raised, and usually opaque (whitish cream). Growth in streaks on potato dextrose agar is spreading, glistening, whitish cream and viscid. Growth in stabs in potato dextrose agar is abundant, with liberation of gas. In nutrient broth, growth is abundant with a thin pellicle or flocculent surface growth, and sediment is scant and viscid. In gelatin stabs, growth is beaded and most abundant near the surface, and the medium is unchanged. Gelatin is not liquefied; nitrates are reduced to nitrites without the formation of gas; hydrogen sulfide is formed; no indole is formed; starch is not hydrolyzed; pectin is not fermented; milk is coagulated; litmus and bromocresol purple are reduced. Methyl red and Voges-Proskauer

*Etymology: Latin; nimis= too much; pressuralis= pertaining to pressure; literally, pertaining to $100 \mathrm{much}$ pressure. tests are positive. Optimum temperature for growth, 24-30 degrees C., maximum 37 degrees C., minimum 5 degrees C. or lower; thermal death point, $45-55$ degrees C. Optimum $\mathrm{pH}$ for growth, 6.82-7.50, maximum $\mathrm{pH} 10.00+$ minimum $\mathrm{pH}+67$.

The organism produces both acid and gas from arabinose, rhamnose, xylose, dextrose, fructose, galactose, mannose, lactose, maltose, trehalose, melibiose, cellobiose, mannitol, sorbitol and salicin; slight acid and gas from starch; no acid or gas from inulin, dextrin or filter paper; variable results from sucrose, raffinose, melezitose, dulcitol, glycerol and elm sawdust.

The organism is pathogenic in trunk wood of elms, Ulmus americana L., U. pumila L., $U$. fulva Michx. and $U$. procera Salisb.

\section{Inoculations}

Inoculation experiments were started in $19+0$ to determine the pathogenicity of the bacterial isolates obtained from diseased elms in Hinsdale that wilted in 1939. Two hundred nine inoculations were made on opening buds, leaves, shoots, branches, trunk phloem, trunk cambium and trunk current-season wood of American elms in our experimental nursery. None of these inoculations produced what were believed to be typical infections or resulted in wilt. Limited browning in trunk wood was produced in inoculated heartwood and older sapwood but was not at first believed to represent infection. However, later experiments showed this browning in trunk wood to represent infection and early development of wetwood. Patch grafting of discolored inner bark from diseased elms in Hinsdale on 28 healthy American elms in our experimental nursery did not produce infection or cause wilt.

American Elm, Greenhouse Inoculations.-Eight American elms, 1.0-1.5 inches d. b. h., grown in a greenhouse pit, were used for this experiment, begun in 1941. Six of the trees were inoculated with Erwinia nimipressuralis by use of a hand syringe, fig. 23-three on July 21 and three on August 5. Each tree was inoculated by injecting $50 \mathrm{ml}$. of bacterial culture in nutrient broth plus dextrose into the trunk through a three-quarterinch hole. In each trunk the injection hole, about $1+$ inches above the ground, was bored at a downward slant and it extended three-fourths of the waly through the trunk. Each injection hole was closed with 
a sterilized cork stopper. Two of the eight trees were used as checks. One check tree was injected with $50 \mathrm{ml}$. of sterile nutrient broth plus dextrose and the other was untreated.

Presence of infection of trunk wood in the inoculated trees was determined by culturing wood samples obtained with an increment borer. One of the six trees pumila L., 2 to 3 inches d. b. h., grown in a greenhouse pit, were used for a second experiment which, like the first, was begun in 19+1. Three of these eight trees were inoculated, each with $50 \mathrm{ml}$. of inoculum -culture of fermenting bacteria in nutrient broth plus dextrose-on October 10 , 19+1. This inoculum was injected by the use of the hand syringe method described

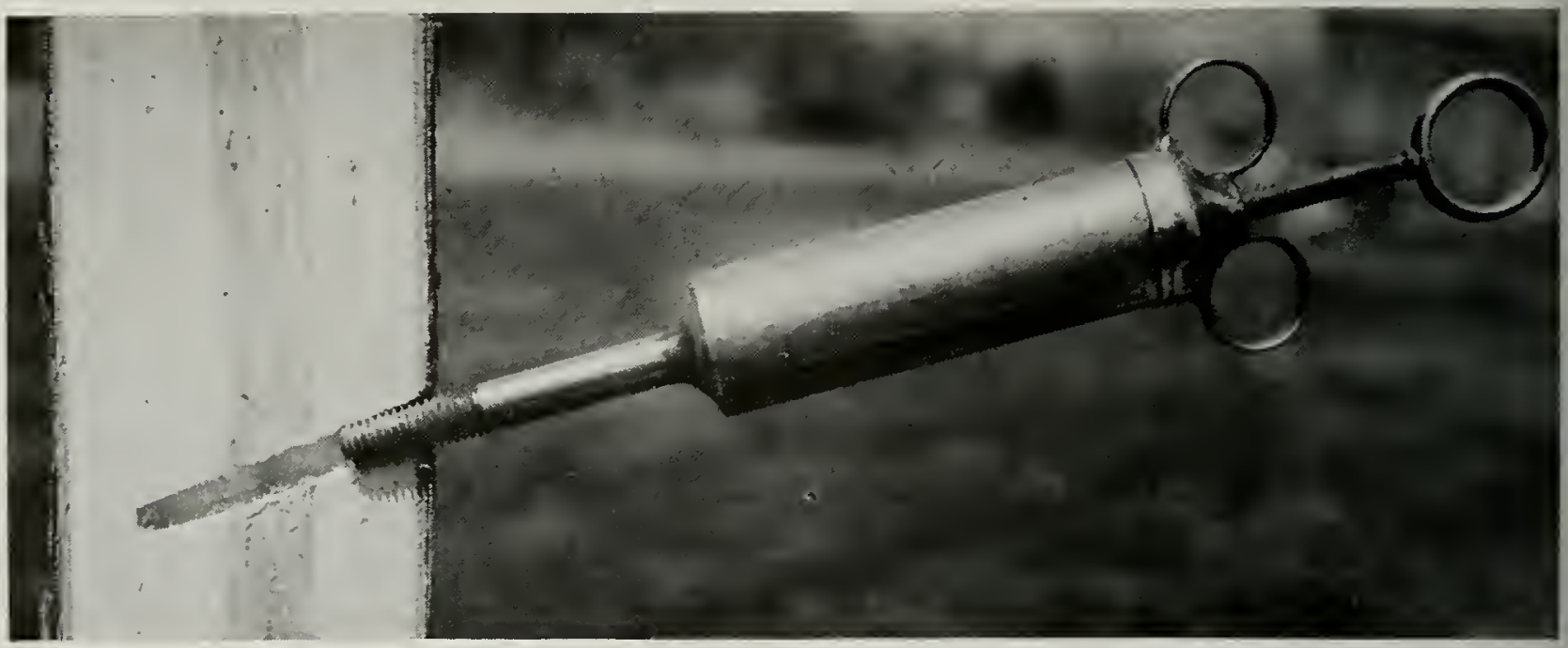

Fig. 23.-Apparatus used for injecting bacterial suspension and other materials into the trunks of elms. The material is injected into the tree through a hole bored in the trunk to within about 1 inch of the bark on the opposite side.

inoculated with bacteria was sampled April 21, 19+2, two were sampled November $13,19+2$, and three were sampled April 10,1943. 'The untreated tree was sampled November 13,19+2, and the tree injected with sterile nutrient broth plus dextrose was sampled April 10, 19+3. The trunk wood samples obtained with an increment borer from the six inoculated trees showed dark brown streaks in the heartwood. This discoloration was comparable to the streaking in elms naturally infected with wetwood. Fermenting bacteria which produced both acid and gas in nutrient broth plus dextrose were isolated from the wetwood tissues of these six inoculated trees. These bacterial isolates were similar to the original inoculum. The untreated tree and the tree injected with nutrient broth plus dextrose showed no dark brown discoloration in the heartwood typical of wetwood. Fermenting bacteria were not isolated from wood of these two check trees. None of the eight trees had wilted by February, 1945, when they were removed from the greenhouse.

Siberian Elm, Greenhouse Inoculations.-Eight Siberian elms, Ulmus above. As a check, another tree was injected with nutrient broth plus dextrose. 'The four remaining trees were untreated.

The four untreated trees and one of the three inoculated trees were cut up and examined on April 13, 1942. In three of the four untreated trees, the 1938 and all older wood was light brown, while the 1939 and all younger wood was white. Brown heartwood and white sapwood are believed to be normal for healthy Siberian elm. Bacteria were not isolated from the trunk wood of these three trees. The other untreated tree was fluxing through cracks in crotches and through a crack in the trunk. The trunkwood showed normal white $19+2$ and $19+1$ wood. The 1940 wood was gray and water-soaked and turned light brown upon exposure to air. The 1939 and older wood was dark brown and showed an infection of wetwood. Fermenting bacteria, which produced both gas and acid, were isolated from the dark brown 1939 wood but not from the grayish, water-soaked 1940 wood or the white $19+1$ and 1942 wood.

The inoculated tree which was examined on April 13, 19+2, had normal white 
the stems were cut, and the presence or absence of bacteria in the solutions tested. The amount of solution $(0.2 \mathrm{ml}$. $)$ from the 24-hour culture of isolate 41-173 taken in by the shoots may have been limited in part by mechanical plugging of vessels by bacteria. However, the tomato shoot in this solution did not wilt, even though the elm shoot in the same test tube wilted in 1.5 hours. Filterable and thermostable toxins were not produced in nutrient broth plus dextrose by isolate 41173. The hydrogen ion concentrations of the solutions used, which ranged from $\mathrm{pH}$ 4.65 to 8.14 , appeared to have no effect on the elm and tomato shoots.

Field Tests on 2-Year-Old Elms. - In this experiment, six 2-year-old potted seedlings of American elm were connected by rubber and glass tubing to six large wetwood-affected elms in Hinsdale to test the toxic effect, on seedlings, of sap from wetwood trees. Two additional potted seedlings were maintained as check trees. Four of the six large elms had wilted in previous years. Sap from the large trees was carried to the seedlings through rubber tubes and improvised glass containers. A glass tube, $29 \mathrm{~mm}$. in diameter, about 3.5-4.0 inches long, was placed around the stem of each seedling to be treated, care being taken not to injure the foliage as the tube was slipped down over the seedling. Rubber stoppers, with holes cut to fit, and split to the outside, were fitted around the stem and inserted in each end of the glass tube. The upper stopper had two additional holes into which two glass tubes were inserted. One of these tubes, plugged with sterile cotton, served as a vent. 'To the other tube was attached rubber tubing which extended to a piece of one-half inch threaded pipe fitted into a hole bored in the diseased tree trunk. The whole apparatus was arranged in such a way that sap from the wetwoodaffected heartwood of the large tree flowed into the glass container around the stem of the seedling.

On each of four of the eight seedlings, a transverse incision was made by removing a $V$-shaped piece of stem. Three of these seedlings were attached by tubes, as described above, to elms affected with wetwood. The fourth, used as a check, was not attached to a tree; its glass container was filled with sterile distilled water.
Each of three of the remaining seedlings was attached, as described above, to an elm affected with wetwood and, when the glass container was full of sap, a transverse incision was made at a downward slant in the stem beneath the surface of the liquid. A similar incision was made in the stem of the single remaining seedling, whose glass container was filled with sterile distilled water.

The two seedlings which received water grew normally throughout the experiment. The three seedlings given sap through $\mathrm{V}$-shaped incisions did not wilt.

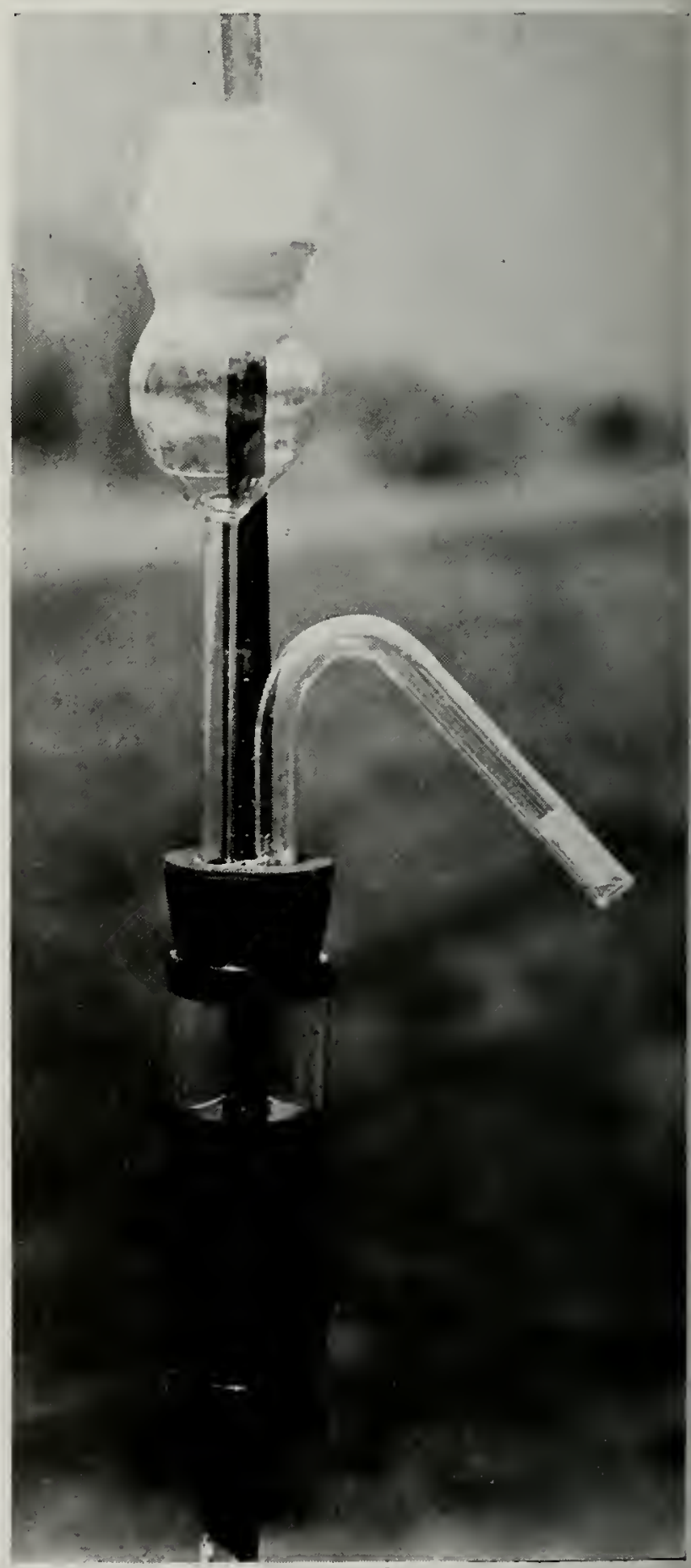

Fig. 24.-Apparatus used in supplying wetwood sap and other materials to potted elms. 
One of them, however, showed some browning of the interveinal tissues of the leaves on the side of the tree directly above the incision. In all of them, grayish brown streaks typical of wetwood developed in the last-formed spring and early summer wood, extending + to 9 inches up the stems and 3 to 6 inches down the stems from the incisions.

The three seedlings which had incisions made in their stems under sap developed wilt. A dull brown or water-soaked condition of the interveinal leaf tissue, similar to that pictured in fig. 16, developed within $2 t$ hours after treatment was started, and was followed in another 24 hours by curling and wilting of the leaves. Each seedling developed grayish brown streaks similar to the streaks found in current-season wood of trees naturally affected with wetwood. These streaks appeared in the last-formed wood, mainly in the spring wood, and extended up the stems from 8 to 24 inches above the incisions and down the stems + to 10 inches below the incisions.

Greenhouse Tests on 2-Year-Old Elms.- The toxicity of sap collected from wetwood-affected elms in Hinsdale and of the materials listed below was tested on 2-year-old greenhouse-grown seedlings of American elm. The materials tested and the number of trees that received each material were as follows: (1) sterile distilled water, as check, 7 trees; (2) unsterilized distilled water, as check, 2 trees; (3) unsterilized sap from diseased elms, + trees; $(4)$ filtrate of sap from diseased elms, + trees; (5) sap from diseased elms, autoclaved, 4 trees; (6) filtrate of sap from diseased elms, autoclaved, 8 trees; (7) precipitate of sap from diseased elms-precipitate obtained by acidifying the sap with sulfuric acid, filtering, then resuspending the precipitate in alkalized water-2 trees; (8) sterile distilled water in which healthy wood was soaked 1 year, 2 trees; (9) water acidified ( $\mathrm{pH}$ 2.62) with hydrochloric acid, + trees; (10) water alkalized $(\mathrm{pH} 9.5+)$ with sodium hydroxide, + trees; (11) suspension of living wetwood bacteria in sterile distilled water, 1 tree; (12) filtrate of nutrient broth staled by growth of the wetwood organism, autoclaved, + trees; (13) filtrate of nutrient broth plus dextrose, staled by growth of the wetwood organism, autoclaved, 2 trees; (1t) suspension of ash from sap in distilled water - suspension obtained by evaporating the liquid and burning out the organic materials-2 trees; (15) filtrate of ash suspension from (14), 2 trees.

The stem of each tree to be treated was fitted with a glass container similar to that shown in fig. 24 . The material to be tested was supplied to this glass container through the thistle tube. A piece of small bore glass tubing, bent in a V shape, was placed in the upper stopper to serve as an air vent. After the container had been filled, the upper stopper was lifted sufficiently to permit insertion of a sterile chisel, and an incision was made in the stem beneath the surface of the liquid; this incision was made across the stem at a downward slant through onethird to one-half of the stem. The stopper was then replaced and sufficient amounts of material were added at intervals to keep the level of the material above the incision and to prevent air from getting into the conductive tissues. The tests were run at different times during the period from July 30 to October 22, 1943, and all were run in duplicate, except that for material (11), suspension of living wetwood bacteria in sterile distilled water. Most tests were terminated at the end of 5 days.

The trees treated with the distilled water, sterile distilled water, acidified water, alkalized water, water in which healthy wood was soaked, precipitate from wetwood sap, water suspensions of living wetwood bacteria, ash from wetwood sap, and filtrate of ash from wetwood sap, maintained their foliage and grew normally throughout the experiment. Data obtained with the other materials, including the check materials, are given in table 3 .

Trees treated with wetwood sap-unsterilized, autoclaved, filtered, and filtered and autoclaved-with filtrate of staled nutrient broth, and with filtrate of staled nutrient broth plus dextrose, showed varying degrees of leaf discoloration, curl and wilt. In general, filtrate of wetwood sap caused the most rapid leaf discoloration, curl and wilt. Bacteria in the wetwood sap did not increase the amount or affect the type of wilt. Filtered sap was absorbed in greater quantities than unfiltered sap. In one test, sap that was filtered and autoclaved, table 3 , caused browning of inter- 
veinal tissues within 6 hours. In the same test, leaf curling or an early stage of wilt developed within 22 hours. This browning and curling occurred during clear weather in August. With most of the materials listed in table 3, browning of interveinal tissues developed in 8 to 36 hours; leaf curl and wilt developed in 22 to 70 hours.

These tests show that toxic materials in the abnormal sap that accumulates in

Table 3.-Results of toxicity tests with sap from infected wood of wetwood-affected elms; sap tested for toxicity on 2-year-old greenhouse-grown elm seedlings. Most tests terminated at the end of 5 days.

\begin{tabular}{|c|c|c|c|c|}
\hline \multirow[t]{2}{*}{ Material Tested } & \multirow[t]{2}{*}{ Tree No. } & \multicolumn{2}{|c|}{$\begin{array}{c}\text { Number of Hours for } \\
\text { Browning and Wilt of } \\
\text { Leaves to ApPear }\end{array}$} & \multirow{2}{*}{$\begin{array}{c}\text { MilliLiters } \\
\text { of } \\
\text { Material } \\
\text { TAKEN UP }\end{array}$} \\
\hline & & BROWNING & Wilt & \\
\hline Sap untreated...... & $\begin{array}{l}1 \\
2 \\
3 \\
4\end{array}$ & $\begin{array}{r}8 \\
8 \\
27 \\
27\end{array}$ & $\begin{array}{l}70 \\
70 \\
48 \\
48\end{array}$ & $\begin{array}{l}27 \\
31 \\
20 \\
24\end{array}$ \\
\hline Sap autoclaved .................. & $\begin{array}{l}1 \\
2 \\
3 \\
4\end{array}$ & $\begin{array}{c}36 \\
36 \\
\text { None } \\
23\end{array}$ & $\begin{array}{c}96 \\
69 \\
\text { None } \\
48\end{array}$ & $\begin{array}{l}31 \\
42 \\
18 \\
79\end{array}$ \\
\hline Sap filtrate........... & $\begin{array}{l}1 \\
2 \\
3 \\
4\end{array}$ & $\begin{array}{r}8 \\
8 \\
21 \\
21\end{array}$ & $\begin{array}{r}70 \\
70 \\
27 \\
27\end{array}$ & $\begin{array}{l}30 \\
71 \\
37 \\
39\end{array}$ \\
\hline Sap filtrate, autoclaved............... & $\begin{array}{l}1 \\
2 \\
3 \\
4 \\
5 \\
6 \\
7 \\
8\end{array}$ & $\begin{array}{r}28 \\
28 \\
24 \\
24 \\
72 \\
6 \\
96 \\
22\end{array}$ & $\begin{array}{c}69 \\
69 \\
40 \\
66 \\
\text { None } \\
22 \\
96 \\
46\end{array}$ & $\begin{array}{l}88 \\
66 \\
92 \\
79 \\
31 \\
75 \\
24 \\
54\end{array}$ \\
\hline Staled* nutrient broth filtrate, autoclaved.... & $\begin{array}{l}1 \\
2 \\
3 \\
4\end{array}$ & $\begin{array}{c}21 \\
21 \\
30 \\
\text { None }\end{array}$ & $\begin{array}{c}28 \\
28 \\
45 \\
\text { None }\end{array}$ & $\begin{array}{r}28 \\
39 \\
68 \\
8\end{array}$ \\
\hline $\begin{array}{l}\text { Staled* nutrient broth plus dextrose filtrate, } \\
\text { autoclaved. } \ldots \ldots \ldots \ldots \ldots \ldots \ldots \ldots \ldots \ldots \ldots \ldots\end{array}$ & $\begin{array}{l}1 \\
2\end{array}$ & $\begin{array}{l}45 \\
21\end{array}$ & $\begin{array}{r}144 \\
45\end{array}$ & $\begin{array}{l}21 \\
20\end{array}$ \\
\hline Sterile distilled water................ & $\begin{array}{l}1 \\
2 \\
3 \\
4 \\
5 \\
6 \\
7\end{array}$ & $\begin{array}{l}\text { None } \\
\text { None } \\
\text { None } \\
\text { None } \\
\text { None } \\
\text { None } \\
\text { None }\end{array}$ & $\begin{array}{l}\text { None } \\
\text { None } \\
\text { None } \\
\text { None } \\
\text { None } \\
\text { None } \\
\text { None }\end{array}$ & $\begin{array}{l}72 \\
39 \\
33 \\
26 \\
45 \\
34 \\
57\end{array}$ \\
\hline Distilled water.......... & $\begin{array}{l}1 \\
2\end{array}$ & $\begin{array}{l}\text { None } \\
\text { None }\end{array}$ & $\begin{array}{l}\text { None } \\
\text { None } \\
\text { - }\end{array}$ & $\begin{array}{l}60 \\
43\end{array}$ \\
\hline
\end{tabular}


tissues affected with wetwood can cause wilt and that, for the production of wilt, Erwinia nimipressuralis need not be carried into the branches and leaves.

The first evidence of leaf discoloration, as shown in the greenhouse tests, is a faint dull browning of the subepidermal cells in the interveinal tissues. Visible only when the leaf is held up to the light, the discoloration is followed within a few hours by more pronounced browning of the upper and lower epidermal cells that spreads toward the lateral veins, fig. 16. This leaf browning, which is similar in appearance to a type of midsummer leaf scorch commonly seen in Illinois on large fluxing elms, continues to spread until the whole leaf margin is brown, and it is followed by curling or wilting of the leaf. Frequently the brown tissues are bordered by a yellow band. Leaves usually are brown and dead within 3 to 6 days from the time the sap is introduced. Such affected leaves abscise easily.

The treated trees were examined for internal symptoms. A water-soaked appearance in the current-season wood, together with brown streaks typical of wetwood, developed only in the trees given wetwood sap through incisions. However, not all of the trees that received wetwood sap showed both of these symptoms. In trees treated with acidified and alkalized water the current-season wood was water-soaked but had no typical brown discolorations. The water-soaked appearance of the wood depends upon the amount of moisture present and can occur in healthy as well as wetwood-affected trees. Wetwood sap, however, is brown in color and it makes the wood it affects appear darker than healthy wood. Cut ends of stems or branches affected with wetwood lose this water-soaked appearance after drying.

Grayish brown streaks appeared in current-season wood of trees given unsterilized and autoclaved wetwood sap and its filtrate. 'They did not appear in the wood of the trees given the autoclaved filtrate or the water suspension of living bacteria. A brown flocculent precipitate was formed when the filtrate was autoclaved. The filtrate was much lighter brown or tan after the precipitate was removed. This indicates that streaking in current-season wood is largely dependent upon the amount or intensity of color in the wetwood sap that passes through it.

Wilt did not occur in trees given acidified ( $\mathrm{pH} 2.62)$ or alkalized ( $\mathrm{pH} \mathrm{9.5+)}$ water, indicating that the $\mathrm{pH}$ reaction ( $\mathrm{pH} 7.5$ to 10.0 ) of wetwood sap has no relation to the production of wilt. The toxic material in wetwood sap was not removed by precipitation, but it was destroyed when the sap was reduced to ash by burning. Trees treated with an ash suspension did not wilt.

From this experiment it appears that a toxic agent is produced by Erwinia nimipressuralis grown in nutrient broth and in nutrient broth plus dextrose. However, the cut shoot experiment described earlier indicates that very little toxic material was produced in nutrient broth plus dextrose. In the earlier experiment, cut shoots of elin placed in wetwood sap wilted in 1.5 hours, while those placed in the filtrate of staled nutrient broth plus dextrose did not wilt in 10.0 hours.

Greenhouse Tests on 7- to 12 Foot Elms.-An experiment was carried out to determine whether wetwood sap and other materials listed below would be readily taken in through elm leaders onefourth to one-half inch in diameter and whether any of these materials would cause wilt. Seven American elms, 7 to 12 feet tall, growing in 1 -inch flower pots in the greenhouse were selected for this experiment. Each tree was treated with a different material. The materials tested were (1) sterile distilled water, used as a check, (2) wetwood sap, (3) filtrate of wetwood sap, autoclaved, (t) fermenting wetwood bacteria in nutrient broth culture, (5) filtrate of nutrient broth staled with fermenting wetwood bacteria, autoclaved, (6) fermenting wetwood bacteria in sterile distilled water and (7) fermenting wetwood bacteria in sterile distilled water, autoclaved.

A leader of each tree was bent over and fastened in such a position that when a bottle containing the material to be introduced was slipped over the cut end of the leader the liquid would not run out. Before the leader was cut, bark on the portion of the stem to be immersed in the solution was disinfected with 70 per cent alcohol and then rinsed with sterile distilled water. After the stem end was immersed in the solution, sterile cotton was packed in the bottle mouth around the 
leader. Each cut leader remained in its respective solution for 5 days. As each bottle was removed, the cut end of the leader was wrapped with rubber tape to prevent the wood from drying out.

Filtrate of wetwood sap, of which 291 ml. were taken up in 5 days, caused browning and wilt of foliage on the two upper branches nearest the cut end of the treated leader; the two branches were, respectively, 9 and 12 inches below the cut. Browning appeared within 24 hours, wilt within the next 24 hours. Leaves near the base of the two branches turned brown and wilted 24 hours before the leaves at the tips. All of the leaves, 50 in number, on these two branches wilted and turned brown within 72 hours, and abscised within 10 days. In 45 days the treated leader had died back 8 inches, to within 1 inch of the uppermost lateral branch. Additional dieback had not occurred at the end of 3 months. On subsequent examination a light tan water-soaked condition was found in the current-season wood, especially noticeable in the spring wood; this condition extended down the stem 30 inches.

Wetwood sap, of which $41 \mathrm{ml}$. were absorbed in 5 days, caused slight browning of leaves on the first lateral below the treated leader. However, none of the foliage wilted. The treated leader died back 5 inches in 45 days.

The wetwood organism, Erwinia nimipressuralis, in nutrient broth, in sterile distilled water, and autoclaved in sterile distilled water, did not cause any browning or wilting of leaves. Filtrate of nutrient broth staled with fermenting wetwood bacteria did not cause wilt but prevented callus formation on the end of the cut leader.

Callus developed normally on the cut leaders immersed in sterile distilled water and nutrient broth culture of Erwinia nimipressuralis after a slight initial killing of the cut bark had occurred. It is possible that bark on the leader immersed in water was killed by mechanical injury when the leader was cut. Callus formation was not retarded on the cut leaders which were immersed in water suspensions of living and autoclaved E. nimipressuralis.

In this experiment, browning and watersoaked appearance of the wood was not characteristic of any one treatment. A water-soaked condition developed when wetwood sap, its filtrate, nutrient broth culture of fermenting wetwood bacteria and its filtrate were used. Fine brown streaks developed in current-season wood of the cut leaders when they were immersed in sterile distilled water, a nutrient broth culture of Erwinia nimipressuralis, its filtrate, and a suspension of it in sterile distilled water, but this streaking was not characteristic of that found in wetwoodaffected trees in the field. The trees treated with sterile distilled water, a nutrient broth culture of $E$. nimipressuralis, its filtrate, a suspension of it in sterile distilled water, and an autoclaved suspension of it in sterile distilled water, continued to grow normally throughout the experiment, except for the lack of callus formation at the cut on each leader, as pointed out above.

\section{Pressures in Affected Elms}

Field Studies.-In these studies, the presence of gas and sap under pressure in tree trunks was first noticed in 1941 while increment borings of the diseased trunk wood of wilting elms were being taken. From some trees, a considerable amount of gas and sap flowed out through the increment borer tube (auger) and continued to flow out of the hole in the tree trunk after the increment borer was removed. This flow was accompanied by bubbling and fizzing sounds, indicating that gas was dissolved under pressure in the sap.

According to the studies of MacDougal (1932), MacDougal \& Working (1933), and Beilmann (1940), pressure in trunks of healthy trees, various kinds, is never great, never as much as 1 pound, and is altered mainly by changes in external air temperature. Stautz (1931), Dodge (1937) and May (1942) have pointed out that abnormally high pressures develop in the trunk wood of trees affected with wetwood.

During 1941, as part of this investigation, the pressures in the trunks of 22 wilting elms that were affected with wetwood were measured with a pressure gauge attached to an increment borer, fig. 25 . Pressure readings were taken after the wood core had been removed from the auger and the increment borer had been 
backed up several turns to allow for the greatest possible exposure of diseased wood adjacent to the hole in the trunk. This procedure eliminated errors that

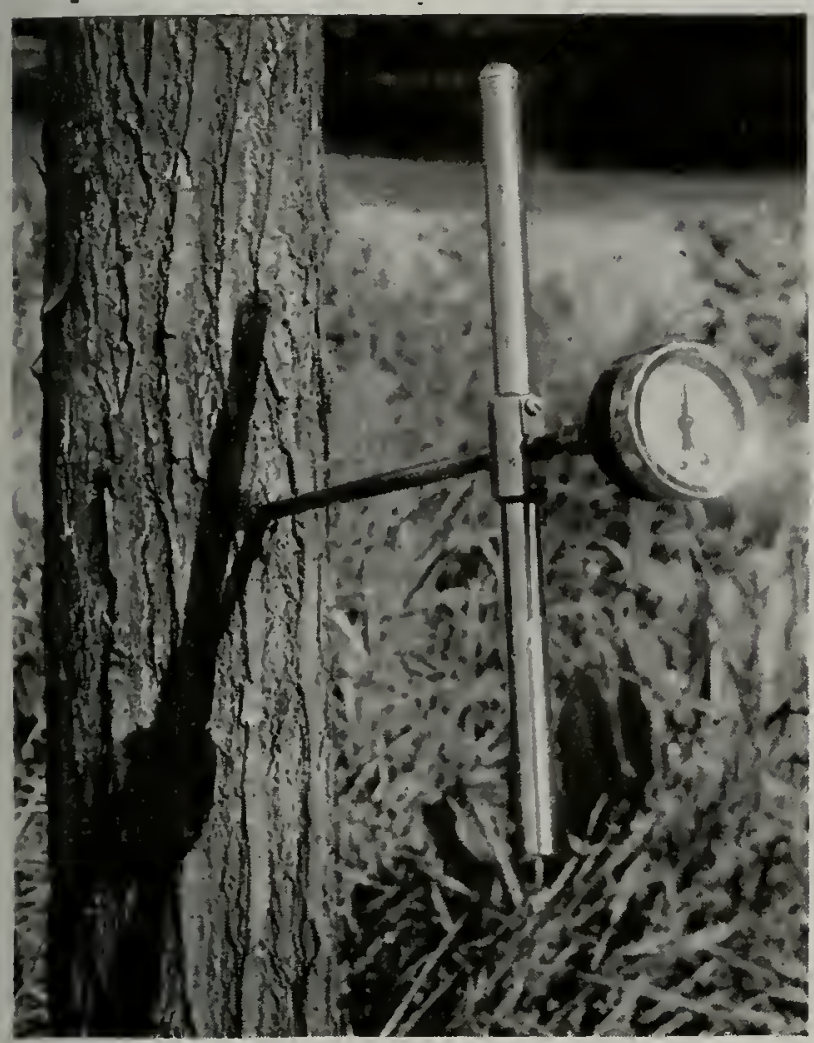

Fig. 25.-Apparatus used for measuring pressure in trunks of elms affected with wetwood. The gauge is attached to the outer end of the increment borer auger. Pressure is recorded by the gauge when the auger enters the wetwood-affected wood, but pressure readings are taken only after the wood core has been removed from the auger. (See text, pages +30 and +31 .) might have resulted from compression of the air in the auger. Pressures read in 13 of the 22 trees ranged from 1.0 to 16.5 pounds. No apparent relation existed between the pressures read and the amounts of branch wilt observed. The higher pressure readings were obtained from trees which either were not fluxing or were fluxing only slightly through cracks in crotches, pruning wounds and other external wounds. However, those trees which gave high pressure readings fluxed strongly through the holes made by the increment borer. All cores obtained with the increment borer from trees giving high pressure readings were discolored dark brown, especially noticeable in the older sapwood and heartwood, and they had a fermentation odor.

Pressures recorded in wetwood-affected trees in $19+1$ were so abnormally high in comparison with the pressures found in healthy elms that additional readings were taken in $19+2$ and 19+3. On April 1, 1942, gaugecock connections were installed, fig. 26, on eight elms at Hinsdale. Readings were taken at irregular intervals during $19+2$ and $19+3$.

In $19+2$, pressures greater than could be accounted for by changes in the outside air temperature or barometric pressure began to develop during April. These pressures continued to increase and reached a peak in August. After they had reached the peak, they gradually declined and had reached zero by February, $19+3$.

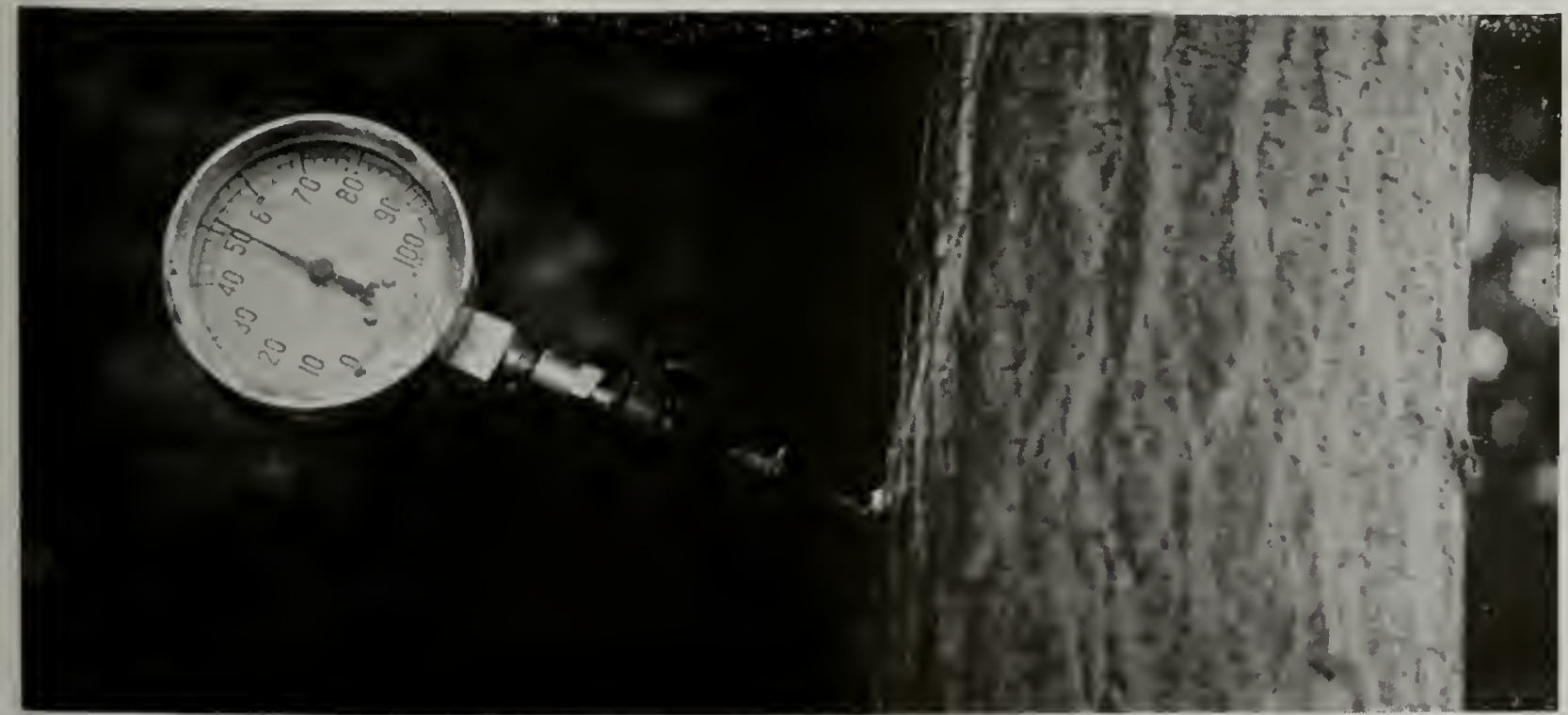

Fig. 26.-Gauge and gaugecock connection used to obtain pressure readings of elms affected with wetwood. This type of gaugecock connection made it possible to obtain pressure readings at will without the escape of gas and sap from the trunk. 
Pressure changes of fractions of a pound, probably induced largely by changes in external air temperatures, were obtained during February and March of 1943. Pressures definitely higher than normal became apparent in April, 1943, and increased until early September, when they
Although the mean maximum temperature for June falls within this range, pressure readings are not then at the maximum, perhaps because of the limited amounts of carbohydrates and other materials available at that time for fermentation in the infected wood. Possibly at that time

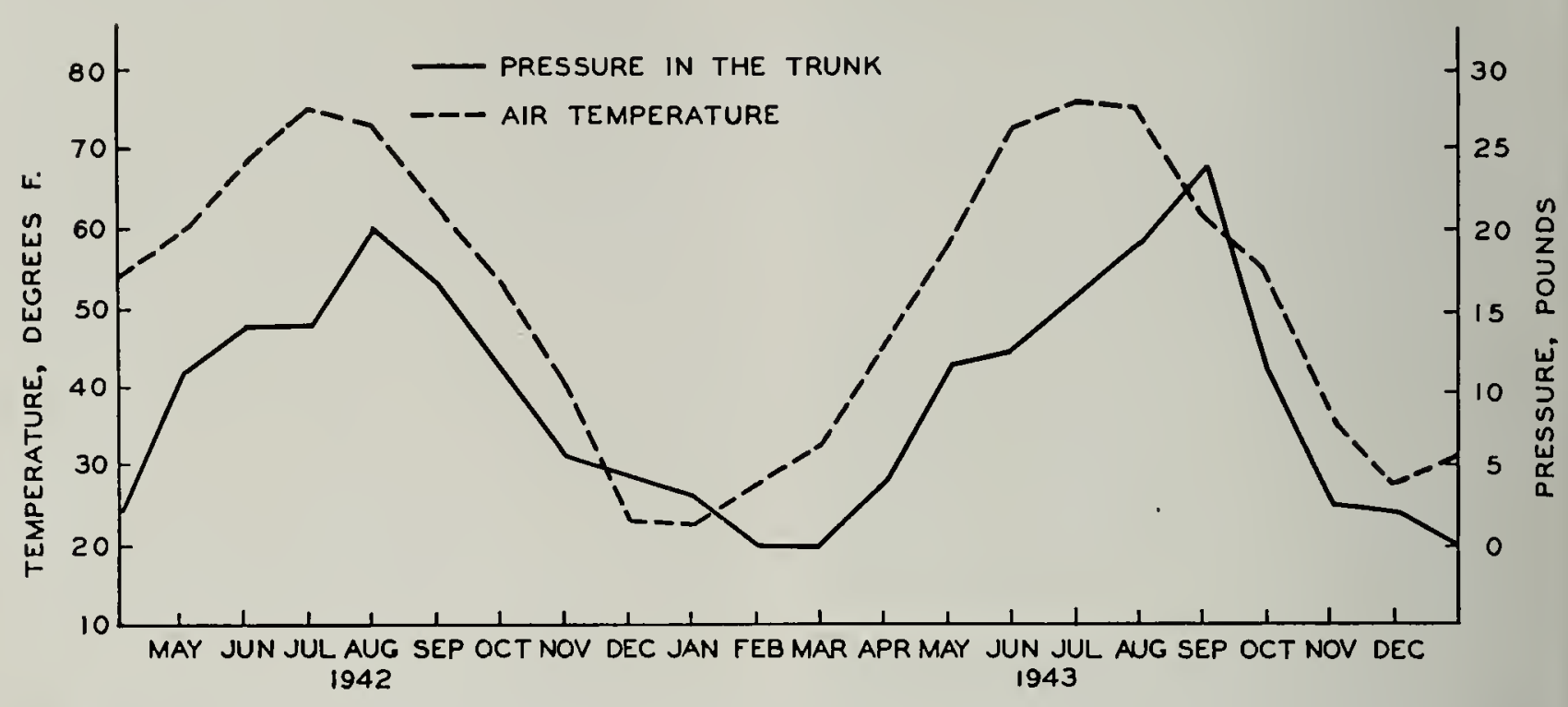

Fig. 27.-The average monthly air temperature and pressure in two non-fluxing wetwood elms in Hinsdale; record covers 22 months. The temperature and pressure curves are similar in shape. However, the peak of the temperature curve occurred in July in each year, while the peak of the pressure curve occurred in August in 1942 and in September in 1943.

reached a peak, following which they gradually declined, dropping to zero by January, 1944.

The relation between the pressure curve and the air temperature curve for the 2 years is shown in fig. 27. The pressure curve represents the average mean monthly pressure readings from two non-fluxing elms in Hinsdale. In shape it is very similar to the mean temperature curve. However, the peaks of the pressure curve occurred in August in 1942 and in September in 1943, while the peaks of the temperature curve occurred in July in both years. The similarity of these two curves indicates that the period of the year when the wetwood organism is most active is in general the period of the year during which high temperatures occur-July, August and early September. The period during which maximum fermentation occurs in the trees, as indicated by maximum pressure readings, is mainly in August when the mean maximum air temperature -22 to 30 degrees C. or 71.6 to 86.0 degrees F.-coincides with the optimum temperature for the organism: 24 to 30 degrees C., or 75.2 to 86.0 degrees $\mathrm{F}$. much of the food of the tree is being used in wood growth. According to Priestly (1930), Beilmann (1935) and MacDougal $(1936,1938)$, xylem growth in several species of trees is most rapid during late April, May and June. MacDougal (1938) reported that cambial activity of elm ceases about August 1 in New York state.

A pressure of 60 pounds per square inch, recorded for one elm tree in Hinsdale on June 20,1942, is quite remarkable when it is compared with pressures recorded by MacDougal (1932) and Beilmann (1940) for healthy trees of various species. MacDougal found internal maximum trunk pressures of $20 \mathrm{~mm}$. of mercury and Beilmann $18 \mathrm{~mm}$. of water. MacDougal \& Working (1933, page 85), who studied gas pressures of the pneumatic system of trees, reported positive pressures of not more than $20 \mathrm{~mm}$. of mercury (approximately 0.3868 pound) ".... and never more than a few millimeters less than barometric." The elm in Hinsdale which developed 60 pounds of pressure in 1942 had wilted during 1941. A gaugecock was installed in this tree on 
for the period November, $19+4$, to the end of February, 19+4. The maximum pressure in this tree occurred in September, 1943. Diseased elms under observation in Hinsdale this same year also produced maximum pressures in September.

The low pressure of 1.5 pounds which occurred in June was recorded while the tree was fluxing through a crack in a branch crotch 3 feet above the gaugecock. To test the effect of drainage on fluxing, the gaugecock was left open from June 7 until the crotch stopped fluxing on June 11. Then the gaugecock was closed, and fluxing began again on June 15 . The gaugecock was reopened at once and the crotch stopped fluxing on June 17 . Thereafter the gaugecock was kept closed, and the amount of fluxing was not sufficient from that time on to prevent the formation of callus. The crotch crack was sealed with callus on July 18, and fluxing ceased.

Pressure in the trunk of this wetwoodinfected tree was found to follow a diurnal cycle as well as an annual cycle. Both pressure and air temperature readings during a period of 2 days and 1 night were recorded on August 3-4 and August 12-13, 19+3, fig. 29. On August 3, when the air temperature did not go much above the optimum temperature range for the wetwocd organism, the maximum pressure cccurred at 1:15 P.M. On August 4, 12 and 13 , when the air temperature had risen above the optimum temperature for the organism by 9:00 A.M., the maximum pressure occurred between $8: 30$ and $11: 00$

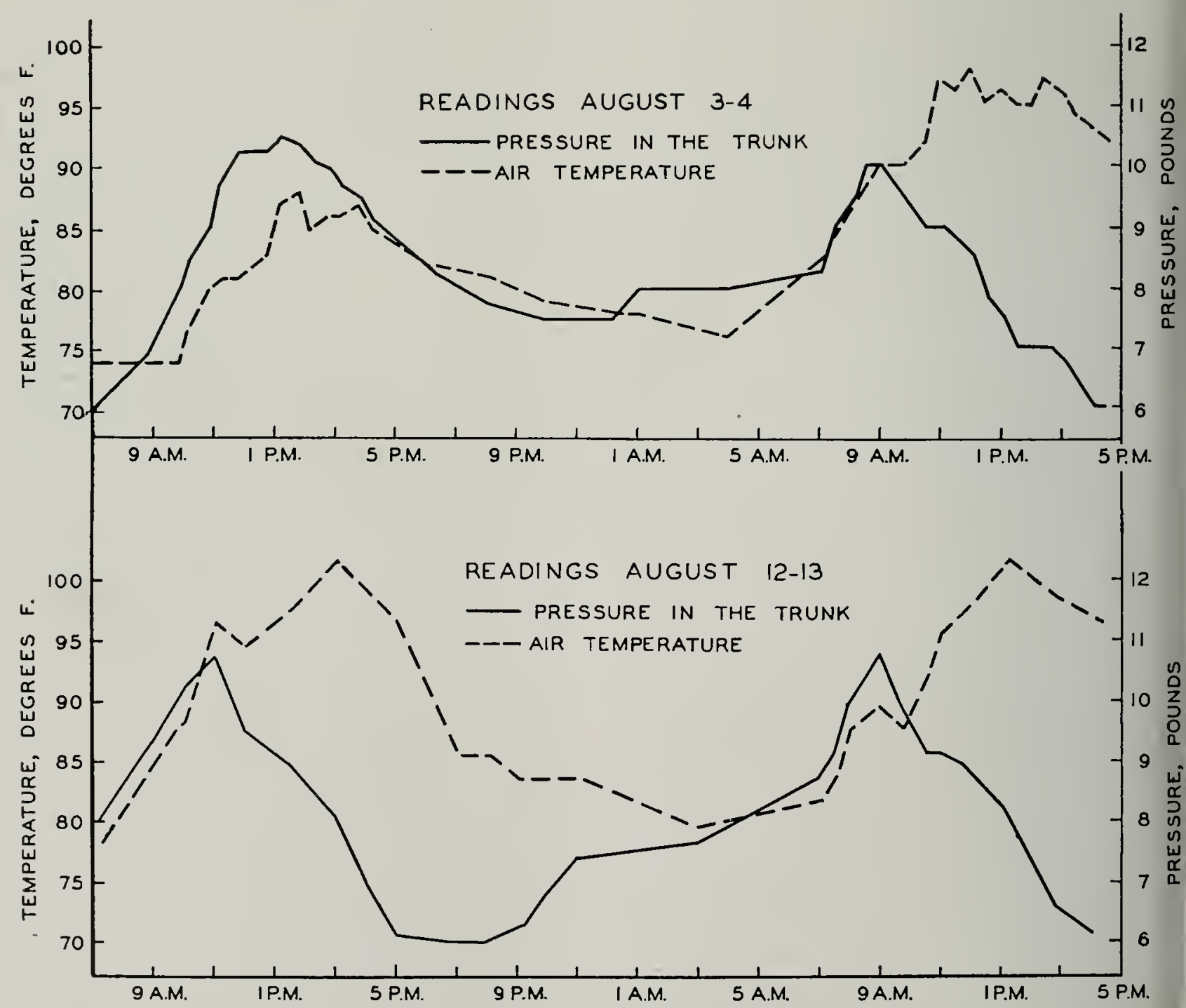

Fig. 29.-Air temperatures and pressures in one greenhouse-grown elm artificially infected with wetwood were recorded during two 34-hour periods. Pressure in the greenhouse trec followed a diurnal cycle. When the air temperature did not go much above the optimum $i \in m$ perature for the wetwood organism, maximum pressure occurred at $1: 15$ P.M. When the air temperature had risen above the optimum temperature for the organism by 9:00 A.M., maximum pressures occurred between 8:30 and 11:00 A.M. Minimum pressures occurred between 7:05 P.M. and 12:10 A.M. 
A.M. The minimum pressure occurred between 10:00 P.M. on August 3 and 12:10 A.M. on August $t$ and between $7: 05$ and 8:00 P.M. on August 12. These observations indicate that the diurnal pressure maximum pressures and maximum temperatures occurred most of ten at 1:00 P.M. These data show, as did the temperature and pressure curves for August 3 and 12, that pressure reaches its maximum at

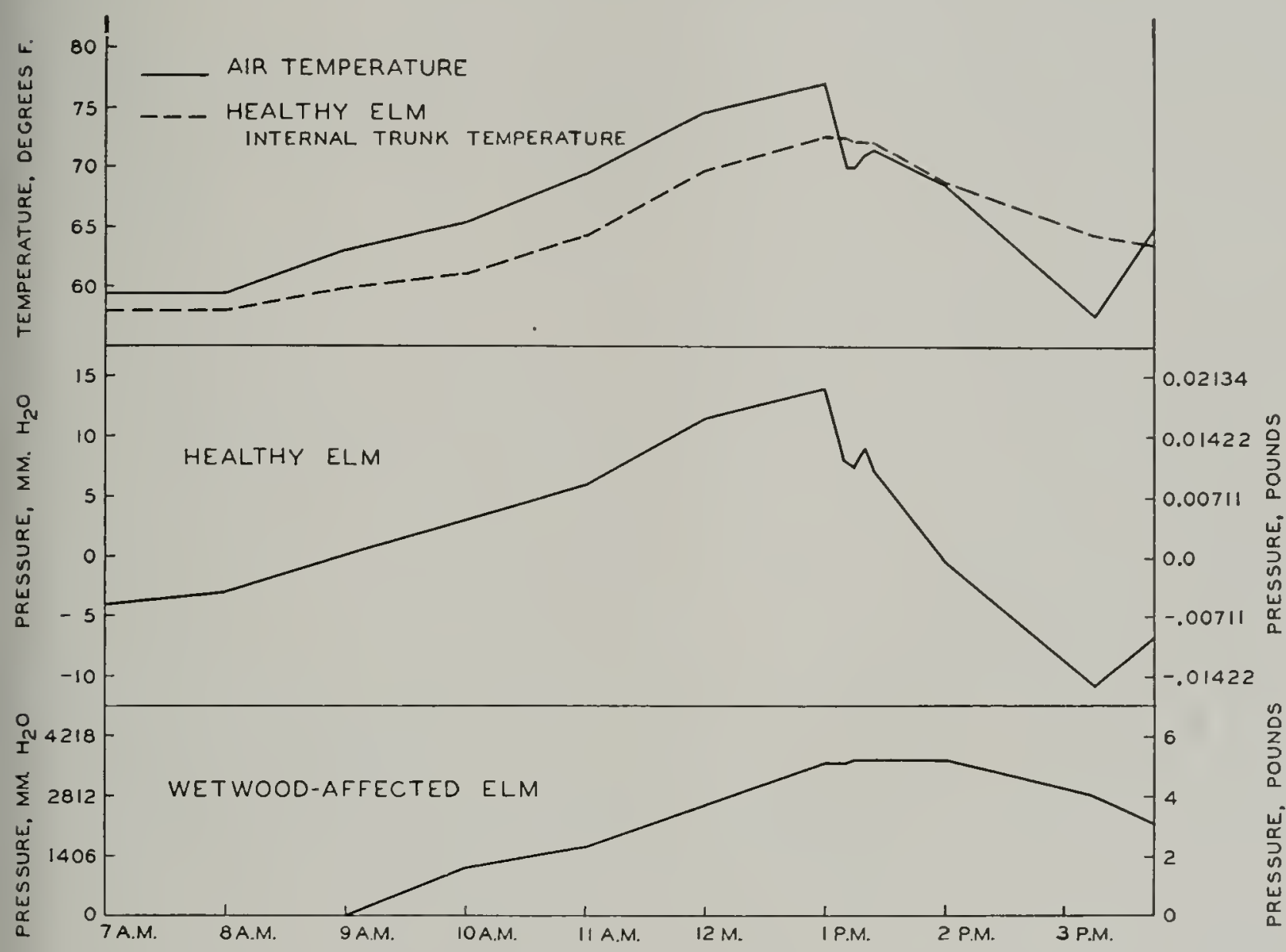

Fig. 30.-Air temperatures, internal trunk temperatures in a healthy tree, and pressures in a healthy tree and in a wetwood-affected tree, all three trees greenhouse-grown; recorded on November 16, 19+3. The trunk temperature curve and the pressure curve for the healthy trees are similar in shape to the air temperature curve. A rapid drop in air temperature between 1:00 and 1:10 P.M. did not cause a similar drop in pressure in the wetwood-affected tree. Pressure in the diseased tree did not decrease until the air temperature dropped below 68.5 degrees $F$. Zero represents atmospheric pressure.

cycle in wetwood-affected trees is not influenced by changes in air temperature, as long as the air temperature is in the optimum range for the organism. However, air temperatures above and below the optimum range for the organism apparently influence the rate of fermentation and thus affect pressure.

Pressure and air temperature readings were taken at 15-, 30- or 60-minute intervals on 17 days between August 2 and September 1 and on 15 days between September 29 and November 16, 19+3. For the 17 days, maximum pressures occurred most often at 11:00 A.M., while maximum temperatures occurred most often at 1:00 P... F. For the 15 day's, both about 11:00 A.s., when the maximum air temperature is above the optimum temperature range for the wetwood organism. However, when the maximum air temperature is not above the optimum temperature range of the organism, pressure and temperature both reach their maxima at about 1:00 P.M. The pressure cycle does not reach a second peak during any one day, regardless of the variations in air temperature. This experiment indicates, as did the previous one, that the diurnal pressure cycle is not influenced by changes in air temperature so long as the air temperature is in the optimum range for the organism.

The relationship between air tempera- 
ture, trunk temperature in a healthy tree and pressures in a healthy tree and in a wetwood-affected tree was studied from October 5, 1943, to January 13, 1944. Curves in fig. 30 , which are typical, show the readings for November 16. Air and trunk temperature readings are given in degrees Fahrenheit, pressure readings from the healthy tree as millimeters of water, and pressure readings from the wetwoodaffected tree as pounds per square inch.

The air temperature curve shows a gradual increase from $8: 00$ A.M. until $1: 00$ P.M., when the temperature reached 77 degrees F. Opening the greenhouse ventilator between $1: 00$ and $1: 10$ P.M. caused the air temperature to drop from 77 to 70 degrees $\mathrm{F}$. This drop was followed by an increase to 71.5 degrees at $1: 25$; then the air temperature declined to 57.5 degrees F. at $3: 15$ P.M., after which it increased to 65 degrees at $3:+5$ P.M. The pressure curve and the trunk temperature curve for the healthy trees are similar to the air temperature curve except that the trunk temperature curve continues to decline between $3: 15$ and $3: 45$ P.M. Reynolds (1939) found temperatures in poplar and cottonwood to be influenced greatly by air temperatures. Pressure in the wetwood-affected tree became apparent by 10:00 A.M. and increased until 1:15 P.M. This pressure stood at a maximum of 5.2 pounds from $1: 15$ to $2: 00$ P.M., but decreased as the air temperature dropped below 68.5 degrees $F$.

The average of the maximum air temperature readings taken in the greenhouse was approximately 83 degrees F. in October, 73 degrees $F$. in November, 66 degrees F. in December and 71 degrees F. in January, while the average of the maximum trunk temperature readings taken was approximately 74 degrees $\mathrm{F}$. in October, 70 degrees F. in November, 68 degrees F. in December and 71 degrees $F$. in January. As no continuous recording devices were used, the maximum temperatures recorded in many cases may not have been the actual maximum temperatures. Air temperatures of 66 to 73 degrees F. are not sufficiently below the optimum temperature for the wetwood organism (75.2 to 86.0 degrees F.) to stop fermentation. Pressures that could be measured with a gauge were present in the wetwoodaffected elm until the tree became dormant about December 1. The average daily maximum pressure was 8 pounds in October and 4 pounds in November, but in December and January the pressure, if any was present, was too low to register on the gauge.

The pressure in the healthy tree did not decrease as did that in the wetwood-affectcd tree and was not noticeably affected by dormancy. The healthy tree had an average daily maximum trunk pressure of 6.7 $\mathrm{mm}$. in October, $7.9 \mathrm{~mm}$. in November, t.8 $\mathrm{mm}$. in December and $6.7 \mathrm{~mm}$. in January.

\section{Gas Analysis}

Gas produced in wetwood-affected elms was analyzed in the field for carbon dioxide and in the laboratory for carbon dioxide, oxygen, hydrogen, methane, carbon monoxide, illuminants and nitrogen. The gas samples analyzed were from trees ranging from 5 to 12 inches d. b. h. Field analyses for the per cent of carbon dioxide in the gas were made by collecting approximately $2+\mathrm{ml}$. of the gas in Smith fermentation tubes over water and by absorbing the carbon dioxide with $\mathrm{N} / 5$ sodium hydroxide.

The gas samples analyzed in the field were collected in August, October and November, 19+2, and in June, July and August, 19+3. 'The analyses tended to show that in August the gas contained more carbon dioxide than it did in preceding or succeeding months. The per cent of carbon dioxide in different trees varied considerably during any one day. There was no correlation between the diameter of the trunk and the per cent of carbon dioxide in the gas. For instance, each of two gas samples collected on August 19, $19+3$, one from a tree 12 inches d. b. h. and one from a tree 5 inches d. b. h., contained 19 per cent carbon dioxide. Gas was not present in sufficient quantities to be collected for analyzing from December, 1942, to May, $19+3$.

Samples of gas were analyzed in an Orsat apparatus, July 2, 1943, and found to consist of approximately 46.4 per cent methane, 33.8 per cent nitrogen, 14.3 per cent carbon dioxide, +.5 per cent oxygen and 1.0 per cent hydrogen. Carbon monoxide and illuminants were not present. The amount of hydrogen recorded (1.0 
per cent) is very small-less than the probable error in a combustion analysis. MacDougal (1932) reported that marsh gas, composed mostly of methane, or any other inflammable gas had not been found in normal trees.

No tests were made in the present investigation to determine whether the gas from the wetwood-affected trees was toxic to foliage of elıns. Crocker (1931), Crocker, Zimmerman \& Hitchoock (1932) and Krone (1937) pointed out that natural gas, which contains about 80 per cent methane, is not highly toxic to trees and other plants.

Gas was produced in abundance when the wetwood organism was grown in nutrient broth plus dextrose. 'The carbon dioxide content of six samples of this gas was determined hy absorption with $\mathrm{N} / 5$ sodium hydroxide and the hydrogen content by passage of the gas through a palladium tube. The samples containcd approximately +4.7 per cent carbon dioxide and 2.t per cent hydrogen. However, it was found that the amount of carbon dioxide contained in the gas varicd with the age of the culture and with the rate of fermentation. More carbon dioxide was produced in young cultures, when the rate of fermentation was most rapid, than in old cultures.

\section{Sap Analysis}

Sap from the trunk wood of elms affected with wetwood was analyzed for calcium, chlorides, copper, iron, magnesium, manganese, phosphate, potassium, sulfatcs, zinc, nitrates, nitrites, ammonia, starch, reducing sugars, indole and erythrodextrin. Also, different quantities of distilled water in which healthy tissue and wetwood tissue had been soaked wcre analyzcd for the materials listed above. 'The methods used in analyzing for these different materials were those given in publications of the Society of American Bacteriologists, Committee on Bacteriological Technic (1939), Merck and Company, Inc. (1940) and Connors \& Tiedjens (19+1). Many of these methods were supplemented by recommendations of Dr. O. WV. Rees, Chemist, Illinois State Geological Survey.

Sap that accumulates in large amounts in elms affected with wetwood can be collected by tapping the trunks of affected trees. In all healthy elms tapped during this experiment, sap was not present in the rood in sufficient quantities to be collected. Analyses were made of distilled water in which wood samples from healthy trees and from wetwood-affected trees had been soaked. Sapwood and heartwood samples of both healthy and diseased trees were tested separately. The water in which the wood had been soaked, and which contained the water-soluble materials of the wood, is referred to below as leach.

All analyses of sap and leach were run in duplicate and most of them were repeated two or more times. Ash of the sap of diseased elms was obtained by evaporating the liquid and burning out the organic material over low heat. This ash was resuspended in distilled water and used as a test material. Also, filtrate of the ash suspension was used as a test material.

The sap-untreated, filtered, and filtered and autoclaved-and the ash suspension filtrate contained a moderate amount of phosphate. In the ash suspension, phosphate was abundant. Only small amounts of phosphate were present in the leaches from wetwood and healthy heartwood. Potassium was abundant in the sap-untreated, filtered, and filtered and autoclaved-and in the ash suspension. There was possibly a trace of potassium in the leach from wetwood tissue but none in the leaches from healthy sapwood and heartwood. Magnesium was not present in any materials tested except for possibly a trace in the ash suspension. No nitrites were found in sap from wetwood tissues or in the leach from healthy heartwood. There appeared to be traces of nitrites in the leaches from healthy sapwood and from wetwood tissues. In our analyses, no calcium, chlorides, copper, iron, manganese, zinc, nitrates, ammonia, starch, indole or erythrodextrin were found in any of the materials tested. The ash suspension contained carbonates but it did not contain bicarbonates or hydroxides. It would seem from this fact that potassium and phosphorus were present as carbonates in the materials tested.

No reducing sugars were detected in sap or in the leaches from wetwood tissues, healthy sapwood or healthy heartwood. There appeared to be traces of reducing 
sugars in the leaches produced by autoclaving healthy sapwood and healthy heartwood. Ogilvie (1924) found no sugar, or only traces of it, in the clear fluid from "water-soaked wood" of elm.

\section{The $\mathrm{pH}$ of Sap}

To ${ }^{\circ}$ compare the $\mathrm{pH}$ of sap from wetwood-affected elms with the $\mathrm{pH}$ of watersoluble materials in the wood and bark of healthy trees and in the wood of trees affected with wetwood, each of the tissues named was soaked in distilled water and the resulting leach, containing watersoluble materials, was tested for its $\mathrm{pH}$. Ten samples of sap and 10 samples of wetwood leach were alkaline, $\mathrm{pH}$ 7.9, when tested with indicators in the field. Five samples of leach from healthy wood and five samples of leach from healthy bark were acid, $\mathrm{pH}$ 6.3. The distilled water used in these tests was neutral to slightly acid.
The $\mathrm{pH}$ values of wetwood sap and of wetwood leaches, and of healthy wood and healthy bark leaches, were determined with the Youden apparatus in the laboratory on several occasions and are given in table 4 . Both sap and leach from wetwoodaffected elms were alkaline, averaging $\mathrm{pH}$ 7.67 and 7.39 , respectively. The leaches from healthy wood and bark were acid, averaging $\mathrm{pH} 6.35$ and 5.89, respectively. These data indicate that sap in healthy elm wood and bark is acid, while sap in wood affected with wetwood and also the watersoluble materials from wood affected with wetwood are alkaline. This is in general agreement with the findings of Ogilvie (1924), who reported the brown and red flux from elm to have a $\mathrm{pH}$ of 9 or above, and of Crandell, Hartley \& Davidson (1937), who found wetwood-affected tissues of elm and other trees to have a higher $\mathrm{pH}$ value than either live sapwood or true heartwood.

Additional $\mathrm{pH}$ tests were made on fil-

Table 4.- The pH of wetwood sap and of leaches of wetwood, healthy wood and healthy bark of elms. The readings were obtained with the Youden apparatus, with platinum electrodes.

\begin{tabular}{|c|c|c|c|c|c|}
\hline \multirow{2}{*}{ Date Collected } & \multirow{2}{*}{ Tree No. } & \multicolumn{4}{|c|}{$\mathrm{pH} \mathrm{V}_{\mathrm{ALUE}}$} \\
\hline & & $\begin{array}{c}\text { WETWOOD } \\
\text { SAP }\end{array}$ & $\begin{array}{c}\text { WeTWOOD } \\
\text { LEACH }\end{array}$ & $\begin{array}{c}\text { Healthy } \\
\text { Wood Leach }\end{array}$ & $\begin{array}{c}\text { HEALthy } \\
\text { BaRK LEACH }\end{array}$ \\
\hline July $23,1941 \ldots \ldots \ldots$ & $\begin{array}{l}1 \\
2 \\
3 \\
4\end{array}$ & $\begin{array}{l}7.43 \\
7.36 \\
7.80 \\
8.34\end{array}$ & & & \\
\hline August $15,1941 \ldots \ldots \ldots$ & $\begin{array}{l}5 \\
6 \\
7 \\
8 \\
9\end{array}$ & $\begin{array}{l}\ldots \\
7.56 \\
\ldots \\
7.11\end{array}$ & $\begin{array}{l}7.33 \\
7.80 \\
7.06 \\
7.73 \\
7.12\end{array}$ & $\begin{array}{l}6.55 \\
6.53 \\
6.33 \\
6.60\end{array}$ & \\
\hline November $12,1941^{*}$. & $\begin{array}{l}10 \\
11 \\
12 \\
13 \\
14 \\
15\end{array}$ & $\begin{array}{l}7.87 \\
7.31 \\
\ldots \ldots \\
7.62 \\
7.36 \\
7.70\end{array}$ & $\begin{array}{l}7.28 \\
7.24 \\
7.56 \\
7.51 \\
7.29\end{array}$ & $\begin{array}{l}6.11 \\
6.26 \\
6.26 \\
6.18 \\
6.35\end{array}$ & $\begin{array}{l}5.91 \\
5.94 \\
5.75 \\
5.86 \\
6.01\end{array}$ \\
\hline August $11,1942 \ldots \ldots$ & $\begin{array}{l}16 \\
17 \\
18\end{array}$ & $\begin{array}{l}8.55 \\
8.00 \\
7.40\end{array}$ & & & \\
\hline Average $\mathrm{pH} \ldots . .$. & & 7.67 & 7.39 & 6.35 & 5.89 \\
\hline
\end{tabular}

*The materials collected on November 12, 1941, were tested with indicators as well as with the Youden apparatus. All wetwood sap and wetwood samples tested approximately pH 7.9 , while healthy wood and bark samples tested approximately $\mathrm{pH} 6.3$. 
tered and autoclaved sap from wetwoodaffected elms. For these tests a sample of sap was divided into four portions. One portion was untreated, one was autoclaved at 15 pounds for 20 minutes, one was passed through a Berkefeld filter and one was filtered and then autoclaved. The untreated sap had a $\mathrm{pH}$ of $7 .+0$, the autoclaved sap a $\mathrm{pH}$ of 8.09 , the filtered sap a $\mathrm{pH}$ of 6.26 and the filtered and autoclaved sap a $\mathrm{pH}$ of 6.33. Autoclaving resulted in an increase in the $\mathrm{pH}$ of both the unfiltered sap and the filtered sap. When samples of unfiltered and filtered sap were autoclaved, a brown, fluffy precipitate was formed, which settled to the bottom of the container upon standing. The formation of this precipitate may have accounted for the differences in the $\mathrm{pH}$ readings obtained before and after autoclaving.

Sap collected from the diseased tissues of a wetwood-affected tree is alkaline. Supposedly it is, or contains, the products of the long-continued fermentation of fermentable materials present in the tree. In the laboratory, nutrient broth plus dextrose eventually becomes strongly acid (p. +22) as the result of fermentation by Erwinic nimipressuralis. The difference in $\mathrm{pH}$ between fermented sap and fermented medium appears inconsistent. However, Conner, Peterson \& Riker (1937) have shown that the crown gall bacterium, Phytomonas tumefaciens, brings about an acid condition when it is grown with glucose as the main source of energy but an alkaline condition when grown in a medium that does not contain glucose. The wetwood organism likewise brings about an alkaline condition when it is grown in nutrient broth without dextrose. It would seem, therefore, that fermentation as it accurs in the tree goes on when no sugar or only traces of sugar are present. The validity of this assumption is further emphasized by our failure to obtain tests for reducing sugars in any of the sap samples, or in any of the leach samples $(p .+37)$ until after they had been autoclaved.

\section{Control Studies}

Control studies, which were started in $19+0$, included injection of chemicals into trunk wood, fertilization, and installation of trunk drains. The chemicals injected were Helione, mercuric chloride, copper sulfate, silver nitrate, and 8-hydroxyquinolin sulfate. 'The fertilizers used were 10-8-6 commercial fertilizer and urea.

\section{Helione Injections and Feeding} in 1940.-Twenty elms, 3 to 10 inches d. b. h., were selected for this experiment. Nine of these trees had wilted in 1939 and all 20 in July, 1940. The 20 trees were treated.as follows: (1) Eight trees were injected with Helione-2 trees with a $1: 200$ dilution, 2 with a $1: 500$ dilution, 2 with a $1: 750$ dilution and 2 with a $1: 1,000$ dilution-and each received $250 \mathrm{ml}$. of solution. (2) Eight trees were injected with Helione in the same manner as in (1) but were also fed 10-8-6 fertilizer. (3) Four trees were fed 10-8-6 fertilizer but were not injected with Helione.

Helione injections were made during August and September, 1940. Fertilizer was applied during September and October by the punch bar method in amounts of 25,35 and to pounds to $3-4-, 6$ - and 8 -inch trees, respectively.

Subsequent to treatment, seven of the eight trees injected with Helione, but given no fertilizer, wilted in 1 or more years: three in 19+1, two in $19+2$ and three in 19+t. One of the three trees that wilted in $19+4$ had wilted in $19+1$ also. None of the eight trees injected with Helione and given fertilizer wilted in $19+1$, but five of them wilted in $19+2$ and one of these five wilted also in 1943 and 194t. Wilt occurred in all four of the trees which were given no injections but were given fertilizer, two in 19+1, one in $19+2$ and one each year, 19+1-19+4. Only one of the eight injected trees and three of the eight trees that were injected and fed did not wilt during the $t$ years following treatment. Under the conditions of this experiment, injecting with Helione, feeding with 10-S-6 fertilizer or combining both treatments did not appear to be effective in preventing wilt.

Urea Feeding in 1941-42.-Urea was fed by the punchbar method to 10 elms, 3 to 5 inches d. b. h. Five of these trees were fed 15 pounds of urea each and five were fed 25 pounds of urea each. Each tree received half of its dosage of urea in October, 19+1, and the other half in April, 19+2. Previous to treatment, eight of the 10 trees had wilted in 19+1, 
one in 1939 and one in both 1939 and 1941.

Subsequent to treatment, only three of the trees wilted, 1942-1944, one in 1942 and 1944, one in 1943 and 1944 and one in 1944 only. The tree which wilted in 1942 and 1944 had received 25 pounds of urea; the other two had received 15 pounds of urea each.

Drains Installed in 1942.-Drains were installed in 10 affected elms, 4 to 6 inches $d . b$. h, to determine whether provision of an artificial outlet for the abnormally produced sap and gas in the trunk would prevent wilt. In eight trees the drains were installed on March 24, in one tree on May 13 and in one on June 17. Holes were bored into the trunks at an upward slant to within about 1 inch of the cambium on the opposite side. Sections of pipe were then driven into the holes far enough to be firmly held, but an effort was made not to drive them into the wetwood-affected tissue.

Only three of the trees fitted with drains wilted, 1942-1944. One wilted in 1942 and again in 1944, the other two in 1943. The tree which wilted in both 1942 and 1944 fluxed through cracks immediately above and below the drain, and the bark adjacent to these cracks was killed. In the other two trees, it is possible that cracks in the wood, concealed beneath the bark, permitted seepage of toxic sap into current wood, whence it was distributed to branches and leaves, causing wilt.

Injections in 1941 and 1942.-In August of 1941, 10 elms affected with wetwood were selected for this experiment. All 10 trees were wilting but none of them had wilted in 1939 or 1940 . Five of them were injected with mercuric chloride and five with copper sulfate. The five trees injected with copper sulfate were 4 to 6 inches d. b. h. and each tree received $100 \mathrm{ml}$. of a 1:1,000 dilution. The five trees injected with mercuric chloride were 3 to 10 inches $d . b$. h. One 3 -inch tree received $50 \mathrm{ml}$., one 4 -inch and two 5 -inch trees received $100 \mathrm{ml}$. each, and one 10 inch tree received $200 \mathrm{ml}$. of a $1: 1,000$ dilution. Each injection was made with a hand syringe, fig. 23, through a hole bored in the tree to within 1 inch of the cambium on the opposite side. One to four such holes were bored in each trunk, the number of holes depending upon the size of the tree: e. g., one hole in a 3 -inch tree, four holes in a 10 -inch tree. The total dosage for any tree with more than one hole was divided equally among the several holes.

From the results of bactericidal tests made in 1942, the amounts of mercuric chloride and copper sulfate injected into these 10 elms in August, 1941, were estimated to have been inadequate. The 1942 tests were made during February, March and April, and the following concentrations of materials were found to kill the wetwood organism: mercuric chloride, $1: 150,000$; copper sulfate, $1: 1,000$; silver nitrate, $1: 50,000$; and 8-hydroxyquinolin sulfate, $1: 9,000$. On the basis of this information, the elms injected in 1941 were reinjected with the same chemicalsmercuric chloride and copper sulfate-in June, 19+2. Also, additional elms were selected for injection with silver nitrate and 8-hydroxyquinolin sulfate.

The amount of material to be injected into each tree was determined in the following manner. First, a wcod core or boring was obtained with an increment borer, and the diameter of the wood affected with wetwood was measured on the core. Then the probable height of the affected wood in the tree was estimated. $W$ ith these figures, the volume of affected wood was roughly calculated. The amount of chemical injected into each tree was sufficient to give a concentration that would kill the wetwood organism in a volume of water equal to the estimated volume of affected wood. Four elmsthree which had wilted in 1940 and $19+1$ and one which had wilted in 1939 and 19+1-were injected with a 1:500 dilution of silver nitrate; two of these trees were each given $200 \mathrm{ml}$., the third was given $300 \mathrm{ml}$. and the fourth $500 \mathrm{ml}$. Three elms which had wilted in $19 ; 0$ and $19+1$ were injected with a $1: 200$ dilution of 8 -hydroxyquinolin sulfate; one of these trees was given $300 \mathrm{ml}$, the second 800 $\mathrm{ml}$. and the third $1,000 \mathrm{ml}$. After the injections were made, the holes were closed with iron set-screws sterilized with 70 per cent alcohol.

The five trees injected with mercuric chloride in 1942 did not wilt in that year, in 1943 or $19+4$. The five trees injected with copper sulfate and the four injected with silver nitrate did not wilt in 1942 or 
1943 , but two trees injected with copper sulfate and two injected with silver nitrate wilted in 1944. Two of the three trees injected with 8-hydroxyquinolin sulfate did not wilt in $1942,19+3$ or 1944 , but the third tree wilted in 1942 and again in $19+3$.

These tests might be interpreted as indicating that mercuric chloride, copper sulfate, silver nitrate, and 8-hydroxyquinolin sulfate may be of value in controlling wilt. However, it must be borne in mind that of $28+$ trees in Hinsdale that wilted, $1939-1943$, only 73 wilted in more than 1 year. Also, the wetwood organism was isolated repeatedly, $19+2-19+4$, from the wetwood-affected trunk wood of the trees which had received injections in $19+1$ and $19+2$, indicating that the organism was not killed throughout the affected wood by any of the materials injected. Later experiments indicated that most of the material injected went into the younger sapwood, especially the current-season wood, and not into the heartwood or older sapwood.

Injections of mercuric chloride and copper sulfate made in August, 1941, caused the cambium to die back 0.5 to 1.5 inches around many of the injection holes. Most of these injured areas callused over in 19+2. Cambial injury following the injections made in 1942 was negligible, since care was taken to prevent the solutions from coming in contact with the cambium around the injection holes.

\section{Miscellaneous Experiments}

Injections of Toxic and Stimulatory Materials.-An experiment was started on July 29, 1942, to determine whether materials toxic to the wetwood organism, as determined by bactericidal tests, would inhibit or kill bacteria in wetwood-affected trunk wood and subsequently reduce the pressure in the trunk. Also, materials known to stimulate fermentation were injected into other trees to see if pressure could be increased. The toxic materials injected were mercuric chloride, 1:500, copper sulfate, $1: 200$, silver nitrate, $1: 500$, 8-hydroxyquinolin sulfate, $1: 200$ and Elgetol, 1: t0. The stimulatory materials injected were 5 per cent dextrose and nutrient broth plus 1 per cent dextrose. Sterile distilled water was injected as a check material. Each material was injected into a single tree.

A one-half inch hole was bored through the heartwood of each tree to be treated, to about 1 inch from the cambium on the opposite side. A gaugecock was installed in each hole. All injections were made with a hand syringe, fig. 23. After the solutions were injected, the gaugecocks were closed to keep these solutions in the trees. Pressures registered immediately before and immediately after the injections were made and during the remainder of the growing season of $19+2$ and the season of $19+3$ are shown in table 5 .

Following the injection of each material, including distilled water, pressure temporarily increased. However, the pressure in most trees had returned to approximately the initial point within 9 hours after the injections were made. Trunk pressures increased during August and September of 1942 in all trees except the one which was injected with 5 per cent dextrose. Pressure readings obtained from each tree followed the normal pressure curve from June to mid October of 19+3. Failure of the toxic materials to reduce pressure suggested that these materials either had not become distributed throughout the bacteria-infected wood, that through some chemical change they were not toxic to the bacteria after being injected into the wood or that the quantity of materials was not sufficient to produce the desired result.

Distribution of Malachite Green in Elms.- Malachite green was used to study the distribution of materials injected into elms. These tests were made August 31, 19+3, on 8-year-old American elm trees growing in our experimental nursery. Methods of supplying the dye were (1) through a hole bored under dye in the trunk, dye being held against the trunk in a cuplike container that kept the hole submerged while it was being bored and for 10 minutes afterwards; (2) by the hand syringe method, fig. 23 ; (3) by cutting the tree and immersing the cut trunk base in the dye; ( 4 ) by cutting the leader and immersing the cut end in the dye; and (5) by cutting a branch and immersing the cut end in the dye. Two trees were subjected to each method of treatment.

Penetration of malachite green through a hole in the trunk submerged below the 
surface of the dye was not extensive but was similar in both trees. In one tree the dye extended in its upward spread from 0.3 inch in 1938 wood to 16 inches in 1943 wood. It extended in its downward spread from 2 inches in 1941 wood to 5 inches in $19+3$ wood. The dye did not penetrate 1937 and older wood above the hole or $19+0$ and older wood below the hole. It spread laterally beyond the hole 0.1 inch in 1943 to 1941 wood.
With the injection method, penetration of the dye was more extensive than in the test described in the preceding paragraph. The dye in one tree extended in its upward spread from 24 inches in 1939 wood to 36 inches in 1942 wood. It extended in its downward spread from 6 inches in 1938 wood to 12 inches in 1942 wood. It spread only in the midsummer and late summer portions of the 1938 wood, and laterally beyond the injection hole from 0.1 inch

Table 5.-Pounds pressure per square inch registered by elms injected with various materials.

\begin{tabular}{|c|c|c|c|c|c|c|c|c|}
\hline $\begin{array}{c}\text { Date of Pressure } \\
\text { Readings }\end{array}$ & 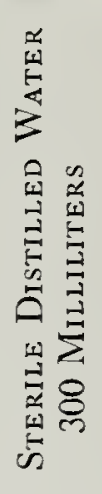 & 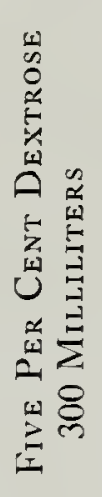 & 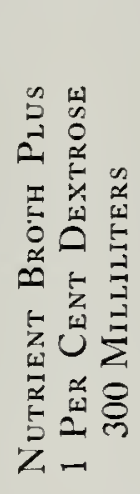 & 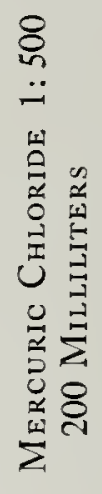 & 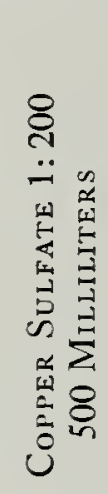 & 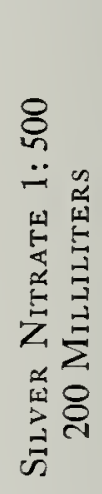 & 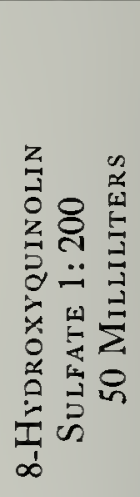 & 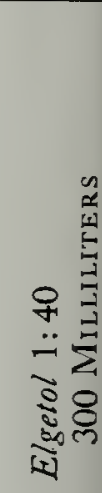 \\
\hline \multicolumn{9}{|l|}{1942} \\
\hline Before injection....... & 1.0 & 3.0 & 0.0 & 6.0 & 3.0 & 7.0 & 16.0 & 1.0 \\
\hline After injection....... & 14.5 & 10.5 & 3.0 & 18.0 & 21.0 & 24.0 & 30.0 & 11.0 \\
\hline 3 hours later........ & 4.0 & 0.5 & - & 11.0 & 7.0 & 一 & 24.0 & 2.0 \\
\hline 9 hours later......... & 4.0 & 1.0 & 0.0 & 10.0 & 3.0 & 10.0 & - & 2.0 \\
\hline July $30 \ldots \ldots \ldots \ldots$ & 5.0 & 1.0 & 1.0 & 11.0 & 5.0 & 11.0 & 一 & 2.5 \\
\hline$\ldots \ldots$ & 4.0 & 0.5 & 1.0 & 12.0 & 6.5 & 11.0 & 30.0 & 2.5 \\
\hline August $4 \ldots \ldots \ldots$ & 4.0 & 0.0 & 2.0 & 6.0 & 12.0 & 9.5 & 27.0 & 1.5 \\
\hline & 3.0 & 0.0 & 8.0 & 15.0 & 8.0 & 11.0 & 30.0 & 3.0 \\
\hline $12 \ldots$ & 6.0 & 2.0 & 9.0 & 10.5 & 11.0 & 8.0 & 15.0 & 1.5 \\
\hline $20 \ldots \ldots \ldots \ldots$ & 7.0 & 3.0 & 13.0 & 12.0 & 12.0 & 10.0 & 24.0 & 1.0 \\
\hline September $4 \ldots \ldots \ldots$ & 6.0 & 1.0 & 11.0 & 12.0 & 13.0 & 8.0 & 21.0 & 1.5 \\
\hline $25 \ldots$ & 1.0 & 4.5 & 8.5 & 7.5 & 7.5 & 5.0 & 13.5 & 0.5 \\
\hline November $18 \ldots \ldots \ldots$ & 一 & - & -1.5 & 3.5 & 1.5 & 1.0 & -1.0 & -1.0 \\
\hline 1943 & & & & & & & & \\
\hline June $3 \ldots \ldots \ldots \ldots$ & 2.0 & 17.0 & 15.0 & 10.0 & 11.0 & 4.5 & 7.0 & 2.0 \\
\hline $4 \ldots$ & 3.0 & 14.0 & 11.5 & 9.0 & 8.5 & 5.5 & - & 2.0 \\
\hline 22. & 11.0 & 15.0 & 20.0 & 10.5 & 13.5 & 5.5 & 一 & - \\
\hline $23 \ldots$ & 9.0 & 14.0 & 18.0 & 11.0 & 13.0 & 7.0 & 6.5 & 2.0 \\
\hline$\ldots \ldots \ldots$ & 11.0 & 15.0 & 20.5 & 12.5 & 15.0 & 7.0 & 7.5 & 2.0 \\
\hline $25 \ldots$ & 11.0 & - & 一 & 13.0 & 16.0 & 7.0 & 7.5 & 3.0 \\
\hline July $7 \ldots$ & 10.0 & - & 24.5 & 12.0 & 17.0 & 6.0 & 6.0 & 一 \\
\hline 8 . & 11.0 & 12.0 & 23.0 & 11.0 & 16.0 & 6.5 & 7.0 & 3.0 \\
\hline 20 . & 11.0 & 14.0 & 20.0 & 11.0 & 16.5 & 5.5 & 6.0 & 4.7 \\
\hline 21 . & 12.0 & 11.5 & 20.5 & 10.5 & 16.5 & 5.5 & 8.0 & 4.5 \\
\hline $22 \ldots$ & 9.5 & 14.0 & 22.0 & 11.0 & 14.0 & 5.7 & 6.5 & 4.5 \\
\hline $23 \ldots$ & 10.2 & 11.5 & 22.5 & 11.0 & 11.5 & - & 8.0 & - \\
\hline August 17 . & 8.5 & 14.0 & 25.0 & 11.8 & 17.5 & 10.5 & 6.8 & 2.0 \\
\hline $18 \ldots$ & 9.0 & 12.0 & 26.0 & 12.5 & 18.0 & 12.0 & 7.5 & 2.0 \\
\hline $19 \ldots$ & 9.5 & 12.5 & 25.2 & 12.8 & $\cdot 17.8$ & 13.6 & 7.7 & 2.0 \\
\hline September 2. & 12.5 & 14.0 & 20.0 & 12.5 & 18.5 & 19.5 & 一 & 2.0 \\
\hline , $3 \ldots$ & 11.0 & 14.0 & 23.5 & 12.1 & 17.2 & 22.0 & 8.5 & - \\
\hline October $12 \ldots \ldots \ldots$ & 6.0 & 12.5 & - & 8.4 & 11.0 & 5.5 & 2.0 & - \\
\hline
\end{tabular}


in 1938 wood to 0.5 inch in 1942 wood. 1t did not penetrate $19+3$ or 1937 and older wood. However, $19+3$ wood was blocked off by the screwed-in syringe.

Penetration of malachite green was most extensive in the two trees that had their trunk bases submerged in dye for 3 hours. Both trees were about 18 feet tall. The dye spread to the top of the trunk and into some branches in the $19+3$ spring and early summer wood but only 9 feet up the trunk in the $19+3$ late summer wood. It spread upward 8 feet in $19+2$ wood, 7 feet in $19+1$ and 1940 wood, 6 feet in 1939 wood and + feet in 1938 late summer wood. The dye did not penetrate 1937,1936 or 1935 wood, or 1938 spring and early summer wood. Evidently, the 1935-1937 wood had become inactive. The $19+3$ or current-season wood, especially the spring and early summer wood, was the most active in carrying the dye to various parts of the tree.

From the cut leader submerged in malachite green for 3 hours, the dye spread down the trunk 60 inches in $19+3$ spring wood, +2 inches in $19+2$ and $19+1$ wood and 36 inches in 1940 and 1939 wood; 1939 wood was the oldest in this portion of the trunk. The dye spread into branches through the $19+3$ spring and early summer wood and reached the branch tips and penetrated the leaf petioles. These branches were within 4 feet of the cut on the leader and measured 6 inches to 5 feet long.

Penetration of malachite green in a 5vear-old branch, cut 30 inches from the trunk and immersed for 3 hours, was mainly in $19+3$ wood. The dye spread from 22 to 24 inches back from the cut in 19+2-1939 wood. In 1943 wood, mainly $n$ the spring and early summer wood, it pread from the base of the immersed ranch down the trunk 1 foot and up the runk 6 feet. The dye, as it spread up the runk, was carried out into lateral branch's through the $19+3$ spring and early ummer wood.

With all methods of injection except he hand syringe, the distances to which nalachite green penetrated were greatest n current-season wood, especially that ormed in spring and early summer. The lye failed to penetrate heartwood, be:ause, as MacDougal, Overton \& Smith (1929) found, the heartwood of certain
Table 6.-Analysis of Hinsdale, Illinois, parkway soil in which elms affected with wetwood were wilting.

\begin{tabular}{|c|c|c|c|}
\hline SAMPLES & $\mathrm{pH}$ & $\begin{array}{c}\text { Nitrates } \\
\text { (Pounds Per } \\
\text { Acre) }\end{array}$ & $\begin{array}{l}\text { Phos- } \\
\text { Phates }\end{array}$ \\
\hline \multicolumn{4}{|l|}{ Sample 1} \\
\hline Topsoil. & 8 & 5 & Low \\
\hline Subsoil & 8 & 5 & Doubtful \\
\hline \multicolumn{4}{|l|}{ Sample 2} \\
\hline Topsoil. & 8 & 15 & Medium \\
\hline Subsoil. & 8 & 10 & Medium \\
\hline \multicolumn{4}{|l|}{$\begin{array}{l}\text { Sample } 3 \\
\text { (Peat soil) }\end{array}$} \\
\hline Topsoil. & 6 & 10 & Low \\
\hline Subsoil. & 7 & 25 & Low \\
\hline \multicolumn{4}{|l|}{ Sample 4} \\
\hline Topsoil. & 8 & 10 & Medium \\
\hline Subsoil. & 8 & 20 & Doubtful \\
\hline
\end{tabular}

trees is under pneumatic, not hydrostatic, pressure. The failure of the dye to penetrate heartwood suggests that when dextrose, nutrient broth plus dextrose, mercuric chloride, copper sulfate, silver nitrate, 8-hydroxyquinolin sulfate and Elgetol were injected, as described for an earlier experiment, they also failed to penetrate heartwood and on that account could have only temporary effect on fermentation and development of pressure.

Soil Tests.-One topsoil sample and one subsoil sample were collected in September, 1939, from each of four parkway areas in Hinsdale where elms affected with wetwood were wilting. These samples were tested for $\mathrm{pH}$ with a Youden apparatus and for nitrates and phosphates with an Urbana soil-testing kit. The analyses are shown in table 6 . Only in the peat soil area, sample 3 , was the soil neutral to acid, $\mathrm{pH} 6$ to 7 ; both topsoils and subsoils of the other areas were highly alkaline, $\mathrm{pH} 8$. In all samples, nitrates and phosphates were medium to low. Much of the parkway soil in Hinsdale, like that of many other villages and cities, contains considerable quantities of fill, which includes clay, gravel and cinders mixed with loam topsoil. This type of soil, as shown by analyses, is not the most favorable for vigorous tree growth, especially since the optimum pH range for American 
elm is $\mathrm{pH} 6.0$ to 7.5 , according to Spurway (1941).

Elm Seeds.-Seeds were collected from 10 wetwood-affected elms in Hinsdale and planted in the spring of 1941 to ascertain if the disease was transmitted through the seed. Nine of these trees had wilted previous to 1941 , three in 1939 , one in 1940 and five in both 1939 and $19+0$. Verticillium had been isolated from the three trees which wilted in 1939 and from the one tree which had not wilted. The seedlings that were obtained grew normally.

Growth Associations.-Growth of the wetwood organism in association with four fungi-Verticillium albo-atrum R. \& B., Dothiorella ulmi V. \& M., Coniothyrium sp. and Alternaria sp.- - was studied because these fungi were found occasionally in trees affected with wetwood. Each fungus to be tested was planted at the center of a Petri dish of potato dextrose agar, and each test was run in duplicate. Four days later, the wetwood organism was planted in streaks along two sides and about $20 \mathrm{~mm}$. beyond each growing fungus colony. The plates were held 30 days for observation.

The wetwood organism was inhibitory to growth of Verticillium and Dothiorella upon contact. However, this inhibition was overcome in 12 days, and thereafter both Verticillium and Dothiorella grew slowly over the bacterial colonies and spread over the agar beyond. The wetwood organism produced only a slight, temporary inhibition of growth of Coniothyrium and Alternaria. This inhibition occurred when the fungus and bacterial colonies were in contact with each other. Both Coniothyrium and Alternaria grew through and over the bacterial colonies, and the bacteria spread along the hyphae of both fungi. In each test, the bacterial colonies spread more rapidly from the fungus colony than toward it.

\section{Conclusions}

From wetwood-affected elms in Illinois a bacterium was isolated, and with it the wetwood disease was reproduced experimentally. The bacterium is quite similar to Erwinia salicis Day, the watermark disease bacterium, and to Pseudomonas lignicola Westerdijk \& Buisman (1929), but because of certain differences it is regarded as a separate species and has been named Erwinia nimipressuralis, new species.

Erwinia nimipressuralis inhabits mainly the heartwood and older sapwood of the trunk. Fermentation by this organism in the infected wood liberates gas which, if it does not escape, produces high pressure. Sap accumulates in the infected wood and produces the water-soaked condition which gives rise to the name wetwood. Much of the abnormal gas and sap can be drained out of the affected wood by the installation of drains. Radial cracks may occur, probably during the winter months, in wetwood-affected trees. These cracks may or may not reach the cambial region. If they extend to the cambial region, they serve as avenues of escape for the sap and the gas generated in the infected wood. Sap and gas flow out through the trunk cracks, killing the surrounding cambium and forming pockets between the bark and wood. The bark external to these cracks may split; then the sap and gas seep out, and the sap flows down the trunk. In many trees, cracks form in branch crotches, and sap and gas escape through these cracks. Likewise, wounds caused by the removal of branches may allow the sap and gas to escape. The flowing out of the sap and gas through these vents is commonly called fluxing, and the escaping sap and gas are known as flux.

Wilt develops wherever sufficient quantities of the wetwood sap are taken up in the current-season wood and carried to the branches. The severity and extent of wilt appear to depend largely upon the amount of toxic sap that is carried into the branches. Some trees show yellowing of leaves and premature leaf drop in July and August without the development of wilt. Trees that wilt may show symptoms any time during July and August; accasionally they show symptoms in late June and early September also. Although wilting branches may lose all of their foliage, if no twig or branch dieback occurs they may produce a new crop of foliage within 3 weeks. If, however, severe' wilt occurs, not only do the leaves wilt and fall but the twigs and branches die back to larger laterals.

There is very little spread of wetwood into the roots of elms, and usually it does 
not spread below the region of grafting in Moline or other grafted types of elms. In the experimental work reported here, buds, leaves, branch and trunk phloem, trunk cambium and current trunk sapwood inoculated with the wetwood organism did not become infected. 'Trunk heartwood and older sapwood inoculated with fermenting bacteria became infected, and typical wetwood was produced. However, the trees in which the heartwood became infected did not wilt during the 3 years they were under observation.

In the trunks of elms affected with wetwood, high pressures develop, whether the trees wilt or not. These pressures commonly reach 5 to 30 pounds per square inch, and are highest in trees that do not flux. In trees which flux freely, there usually is very little or no pressure. A pressure of 60 pounds per square inch was recorded in one elm in 1942. This tree fluxed freely in 1943 and, while fluxing, developed a pressure of only 1 to 2 pounds. Pressure is absent in February and March but begins to develop in April and early May. Ir increases until August or September; then decreases until late December or January. Pressures recorded in artificially infected greenhouse elms followed the general annual pressure cycle observed in naturally infected elms and were too low to be measured with a gauge when the trees were dormant.

In artificially infected greenhouse elms, a diurnal pressure cycle was observed. The maximum pressure occurred about 11:00 A.M. in June, July and August and about $1: 00$ P.M. in October, and the minimum pressure occurred usually between 7:00 P.M. and 11:00 P.M. The amount of pressure that developed in the greenhouse trees was influenced by air temperature. When the temperature fell much below the optimum temperature range of the wetwood organism-23 to 30 degrees C. or 75.2 to 86.0 degrees F.-pressure in the trees decreased. The pressure recorded in a greenhouse elm not affected with wetwood never exceeded $21 \mathrm{~mm}$. of water, approximately 0.03 pound per square inch, as measured by a water manometer, but the maximum pressure recorded in one greenhouse tree affected with wetwood was 14.8 pounds. The diurnal rise and fall of the pressure curve for a normal tree, of the trunk temperature curve and of the air temperature curve corresponded closely.

Samples of gas from wetwood-affected elms contained approximately 46.4 per cent methane, 33.8 per cent nitrogen, $1+.3$ per cent carbon dioxide, 4.5 per cent oxygen and 1.0 per cent hydrogen. Carbon monoxide and illuminants were absent.

Samples of sap from wetwood-affected elms contained phosphates and an abundance of potassium. Although tests were made for them, the following elements and compounds were not found: calcium, chlorides, copper, iron, magnesium, manganese, sulfates, zinc, nitrates, nitrites, ammonia, starch, reducing sugars, indole and erythrodextrin.

The sap and diseased wood of wetwoodaffected elms are alkaline, while both sapwood and heartwood of normal trees are acid in reaction.

Erwinia nimipressuralis has an optimum temperature range of 24 to 30 degrees C., 75.2 to 86.0 degrees $\mathrm{F}$., a maximum temperature of 37 degrees C., 98.6 degrees $\mathrm{F}$., and a minimum temperature of 5 degrees C., 41 degrees $F$., or less.

\section{Summary}

1. Our investigation of wetwood of elms was started in 1939. In Hinsdale, 1939-1943, $28+$ elms wilted because of wetwood infections in their trunks. None of the $28+$ elms which wilted died, and only 73 wilted in more than 1 year.

2. Wetwood infection has been found in the American elm (Ulmus americana L.) and its cultivated varieties Moline and Littleford, and in the slippery elm (Ulmus fulta Michx.), the English elm (Ulmus procera Salisb.) and the Siberian elm (Ulmus pumila L.). Samples from 346 elms located in 21 counties of Illinois were cultured, and the wetwood organism was isolated from 239 of them. Of the $3+6$ trees, 292 showed wilt at the time the samples were taken.

3. Histological studies show the wetwood bacterium to inhabit principally the vessels and ray-cells of the trunk. It does not grow in sufficient abundance to cause general clogging of the conducting tissues and it does not cause disintegration of the tissues it inhabits.

4. Wetwood and flux were produced by trunk wood inoculations with this bacte- 
rium. Wilt was not produced by these inoculations, nor by inoculations of buds, leaves, shoots or branches. Infection was not obtained by patch grafting with discolored inner bark taken from diseased trees.

5. Sap from wetwood caused young trees to wilt when it was introduced into their current-season wood. It appears that grayish brown streaks in the current-season wood are caused by the discolored sap and not by the wetwood organism. The bacterium was not often isolated from wilting branches.

6. Trunk pressures in wetwood-affected elms commonly reached 5 to 30 pounds per square inch, and were highest in trees that did not flux. A pressure of 60 pounds per square inch was recorded in one tree in 1942. Pressures in wetwood-affected elms began to develop in April and early May, increased until August or September and then decreased until late December or January. Pressures were not detected in February and March. In artificially infected greenhouse trees, pressures fol- lowed a diurnal cycle with a maximum between 11:00 A.M. and 1:00 P.M. and a minimum between $7: 00$ and $11: 00$ P.M.

7. Gas from affected elms contained methane, carbon dioxide, oxygen, hydrogen and nitrogen.

8. Sap from affected elms contained phosphates and potassium.

9. The $\mathrm{pH}$ determinations showed the sap and discolored wood of wetwood trees to be alkaline, the wood of healthy trees to be acid.

10. The bacterium which causes wetwood is a fermenting facultative anaerobe of the genus Erwinia. It is named Erwinia nimipressuralis, new species.

11. Control measures tested included feeding with 10-8-6 fertilizer and urea, installation of drains in trunks, and the injection of mercuric chloride, copper sulfate, silver nitrate, 8-hydroxyquinolin sulfate and Helione. Neither the use of fertilizers nor the injection of any of the chemicals appeared to be effective. The installation of drains, however, gave at least temporary control of flux.

\section{LITERATURE CITED}

Beilmann, August $P$.

1935. The use of instruments in tree diagnosis. Natl. Shade Tree Conf. Proc. 11:18-26.

1940. An attempt to record internal tree-trunk pressures. Mo. Bot. Gard. Ann. $27(3): 365-70$.

Burkholder, Walter $\mathbf{H}$.

1932. Carbohydrate fermentation by certain closely related species in the genus Phytomonas. Phytopath. 22(8): 699-707.

Conner, H. A., W. H. Peterson and A. J. Riker

1937. The nitrogen metabolism of the crown gall and hairy root bacteria. Jour. Ag. Res. 54(8) : 621-8.

Connors, Charles H., and Victor A. Tiedjens

19+1. Chemical gardening for the amateur. Wh. H. Wise and Company, New York. $225 \mathrm{pp}$.

Cook, Mel. T.

1918. Common diseases of shade and ornamental trees. N. J. Ag. Exp. Sta. Circ. 98. 27 pp.

Crandall, Bowen S.

1943. Bacterial infection and decay of the inner wood of winter-injured young London plane trees. Phytopath. 33(10):963-4.

Crandall, Bowen S., Carl Hartley and R. W. Davidson

1937. Wetwood. (Abstract.) Phytopath. 27(2): 126.

Crocker, William

1931. The effect of illuminating gas on trees. Natl. Shade Tree Conf. Proc. 7:24-34.

Crocker, William, P. W. Zimmerman and A. E. Hitchcock

1932. Ethylene-induced epinasty of leaves and the relation of gravity to it. Boyce Thompson Inst. Contrib. 4(2) : 177-218.

Dodge, A. W.

1937. Slime flux. Arborist's News 2(7):1-2. 
Elrod, R. P.

1942. The Erruinia-coliform relationship. Jour. Bact. 44(4): +33-40.

Guba, E. F.

1934. Slime flux. Natl. Shade Tree Conf. Proc. 10: 56-60.

19+2. Slime flux of trees. Arborist's News $7(3): 17-8$.

Hansen, Emil Chr.

1889. Ueber die in dem Schleimflusse lebender Bäume beobachteten Mikroorganismen.

Centbl. f. Bakt. u. Parasitenk. 5(19) :632-40, (20):633-7, (21):693-6.

Hartley, Carl, and B. S. Crandall

1935. Vascular disease in poplar and willow. (Abstract.) Phytopath. 25(1):18-9.

Holtz, Wilhelm

1901. Beitrag zur Kenntnis der Baumflüsse und einiger ihrer Bewohner. Centbl. $f$. Bakt., Parasitenk. u. Infektionskrank. Abt. II, 7(4):113-28, (5, 6):179-89, (7):229$38,(8): 27+-81,(9,10): 338-50$.

Krone, Paul R.

1937. The reaction of greenhouse plants to gas in the atmosphere and soil. Mich. Ag. Exp. Sta. Spec. Bul. 285. 35 pp.

Large, John R.

1944. Alcoholic flux or white slime flux of tung trees. U. S. Dept. Ag. Pl. Dis. Rep. $28(1): 35-6$.

Ludwig, F.

1886. Ueber Alkoholgährung und Schleimfluss lebender Bäume, verursacht durch Endomyces Magnusii n. sp. und Leuconostoc Lagerheimii n. sp. Hedwigia 25 (5) : 168-72. 1888. Der braune Schleimfluss. Centbl. f. Bakt. u. Parasitenk. 4(11):323-4.

1890. Zwei parasitologische Mittheilungen. II. Eine profuse Gummose der Eichen. Centbl. f. Bakt. u. Parasitenk. 8(14): +24-5.

MacDougal, Daniel T.

1932. The pneumatic system of trees. Carnegie Inst. Wash. Yearbook $31: 192-3$.

1936. Studies in tree-growth by the dendrographic method. Carnegie Inst. Wash. Pub. 462. $256 \mathrm{pp}$.

1938. Tree growth. Chronica Botanica Company, Leiden, Holland. 240 pp.

MacDougal, Daniel T., J. B. Overton and Gilbert M. Smith

1929. The hydrostatic-pneumatic system of certain trees: movement of liquids and gases. Carnegie Inst. Wash. Pub. 397. 99 pp.

MacDougal, Daniel T., and Earl B. Working

1933. The pneumatic system of plants, especially trees. Carnegie Inst. Wash. Pub. 441. $87 \mathrm{pp}$.

Massee, George

1897. Slime flux. Kew Bul. Misc. Inf. 132: +23 .

1907. Additions to the wild fauna and flora of the Royal Botanic Gardens, Kew. Saccharomycetaceae. Kew Bul. Misc. Inf. 6:240.

May, Curtis

1942. A note on slime-flux in American elm. Arborist's News 7(7): 52-3.

Merck and Company, Inc.

1940. The Merck Index. Fifth edition. Merck and Company, Rahway, New Jersey. $1,060 \mathrm{pp}$.

Ogilvie, Lawrence

1924. Observations on the "slime-fluxes" of trees. Brit. Mycol. Soc. Trans. 9: 167-82.

Priestly, J. H.

1930. Studies in the physiology of cambial activity. III. The seasonal activity of the cambium. New Phytol. 29(5):316-54.

Reynolds, Ernest S.

1939. Tree temperatures and thermostasy. Mo. Bot. Gard. Ann. 26(3): 165-255.

Society of American Bacteriologists, Committee on Bacteriological Technic

1939. Manual of methods for pure culture study of bacteria. Leaflets $2: 3-15 ; 4: 3-23$;

5:2-20. Seventh edition. Society of American Bacteriologists, Geneva, New York.

Spurway, C. H.

1941. Soil reaction (pH) preferences of plants. Mich. Ag. Exp. Sta. Spec. Bul. 306.36 pp.

Stautz, Walter

1931. Beiträge zur Schleimflussfrage. Phytopath. Ztschr. 3(2): 163-229. 
Stone, George E.

1916. Shade trees. Mass. Ag. Exp. Sta. Bul. 170. 264 pp.

Tubeuf, Karl Freiherr von, and William G. Smith

1897. Diseases of plants induced by cryptogamic parasites. Longmans, Green and Company, New York. 598 pp.

Ward, H. Marshall

1901. Diseases in plants. The Macmillan Company, New York. 309 pp.

Westerdijk, Johanna, and Christine Buisman

1929. De Iepenziekte. Rapport over het Onderzoek Verricht op Vorzoek van de Nederlandsche Heidemaatschappij. Nederland. Heidemaatsch. te Arnhem. 78 pp. 

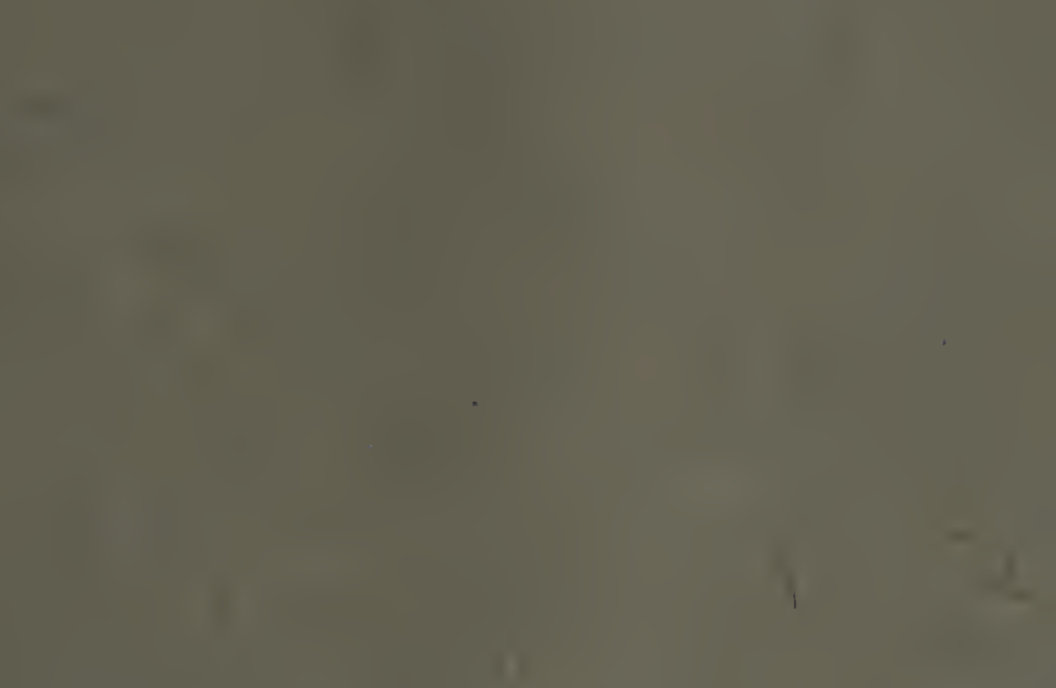


\section{Recent Publications}

\section{A.-ILLINOIS NATURAL HISTORY SURVEY BULLETIN.}

Volume 21, Article 6.-Preliminary Investigation of Oak Diseases in Illinois. By J. Cedric Carter. June, 1941. 36 pp., frontis. + 51 figs., bibliog. (Bound with Article 7.)

Volume 21, Article 7.-A Needle Blight of Austrian Pine. By Robert L. Hulbary. June, 1941. 6 pp., frontis. +3 figs., bibliog. (Bound with Article 6.)

Volume 21, Article 8.-Duck Food Plants of the Illinois River Valley. By Frank C. Bellrose, Jr. August, 1941. 44 pp., frontis. + 35 figs., bibliog., appendix.

Volume 22, Article 1. - The Plant Bugs, or Miridae, of Illinois. By Harry H. Knight. September, 1941.234 pp., frontis. +181 figs., bibliog., index. $\$ 1.25$.

Volume 22, Article 2.- Studies of North American Plecoptera, with special reference to the fauna of Illinois. By T. H. Frison. September, 1942. 122 pp., frontis. +126 figs., bibliog., index. $\$ 1.00$.

Volume 22, Article 3.-Management of Small Artificial Lakes: a summary of fisheries investigations, 1938-1942. By George W. Bennett. February, 1943. 20 pp., frontis. +7 figs., bibliog.

Volume 22, Article 4.-The Prairie Chicken in Illinois. By Ralph E. Yeatter. May, 1943. $40 \mathrm{pp}$., frontis. +18 figs., bibliog. (Bound with Article 5.)

Volume 22, Article 5.-Preferential Rating of Duck Food Plants. By Frank C. Bellrose, Jr., and Harry G. Anderson. May, 1943. 16 pp., frontis. + 16 figs., bibliog. (Bound with Article 4.)

Volume 22, Article 6.-Survey of the Illinois Fur Resource. By Louis G. Brown and Lee E. Yeager. September, 1943. 70 pp., frontis. + 33 figs., bibliog. (Bound with Article 7.)

Volume 22, Article 7.-Illinois Furbearer Distribution and Income. By Carl O. Mohr. September, 1943. 33 pp., frontis. +24 figs., bibliog. (Bound with Article 6.)

Volume 23, Article 1. - The Caddis Flies, or Trichoptera, of Illinois. By Herbert H. Ross. August, 1944. 326 pp., frontis. + 961 figs., bibliog., index. $\$ 1.50$.

Volume 23, Article 2.-Duck Populations and Kill. By Frank C. Bellrose, Jr. November, 1944 . 46 pp., frontis. +27 figs., bibliog.

Volume 23, Article 3.-Overfishing in a Small Artificial Lake; Onized Lake near Alton, Illinois. By George W. Bennett. May, 1945. 34 pp., frontis. + 15 figs., bibliog.

\section{B.-ILLINOIS NATURAL HISTORY SURVEY CIRCULAR.}

32.-Pleasure With Plants. By L. R. Tehon. November, 1942. (Second printing, with revisions.) 32 pp., frontis. +9 figs.

33.-Controlling Peach Insects in Illinois. By S. C. Chandler and W. P. Flint. August, 1939 . 40 pp., frontis. + 32 figs.

34.- Rout the Weeds! Why, When and How. By L. R. Tehon. August, 1943. (Third printing.) 47 pp., color frontis. +13 figs.

35.-Diseases of Small Grain Crops in Illinois. By G. H. Boewe. September, 1939. 130 pp., frontis. +47 figs.

36.-Planting and Care of Shade Trees. By J. E. Davis. March, 1941. 23 pp., frontis. +16 figs.

37. - Outwitting Termites in Illinois. By W. E. McCauley and W. P. Flint. August, 1942. (Second printing.) 23 pp., frontis. + 19 figs.

38. - Windbreaks for Illinois Farmsteads. By J. E. Davis. February, 1942. (Secon printing.) 24 pp., frontis. + 19 figs.

39.- How to Collect and Preserve Insects. By H. H. Ross. May, 1944. (Secon) printing, with additions.) 55 pp., frontis. + 63 figs.

40.-Control of Roundheaded Apple Tree Borer. By S. C. Chandler and W. P. Flinl April, 1942. 8 pp., 6 figs.

C.-ILLINOIS NATURAL HISTORY SURVEY MANUAL.

1.-Fieldbook of Illinois Wild Flowers. By the staff. March, 1936. 406 pp., coln frontis. +349 figs., index. $\$ 1.50$.

2.-Fieldbook of Illinois Land Snails. By Frank Collins Baker. August, 1939. pp., color frontis. +170 figs., 8 pls. $\$ 1.00$.

3. Fieldbook of Native Illinois Shrubs. By Leo R. Tehon. December, 1942. $307 \mathrm{pp}$. 4 color pls. +72 figs., glossary, index. $\$ 1.25$.

List of availuble publications, abont 400 titles, mailed on request.

Address orders and correspondence to the Chief

ILLINOIS NATURAL HISTORY SURVEY

Natural Resources Building, Urbana, Illinois

Paymeat in the form of U.S. Post Office money order made out to

State Treasurer of Illinois, Springfield, Illinois,

must accompany requests for those publications on which a price is set. 